\title{
ॠUSGS
}

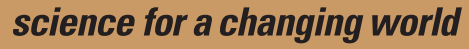

Prepared in cooperation with the State of Hawai' $i$ Department of Health Clean Water Branch

\section{Source-Tracking Approach for Detecting and Identifying Sources of Wastewater in Waters of Hawai'i}
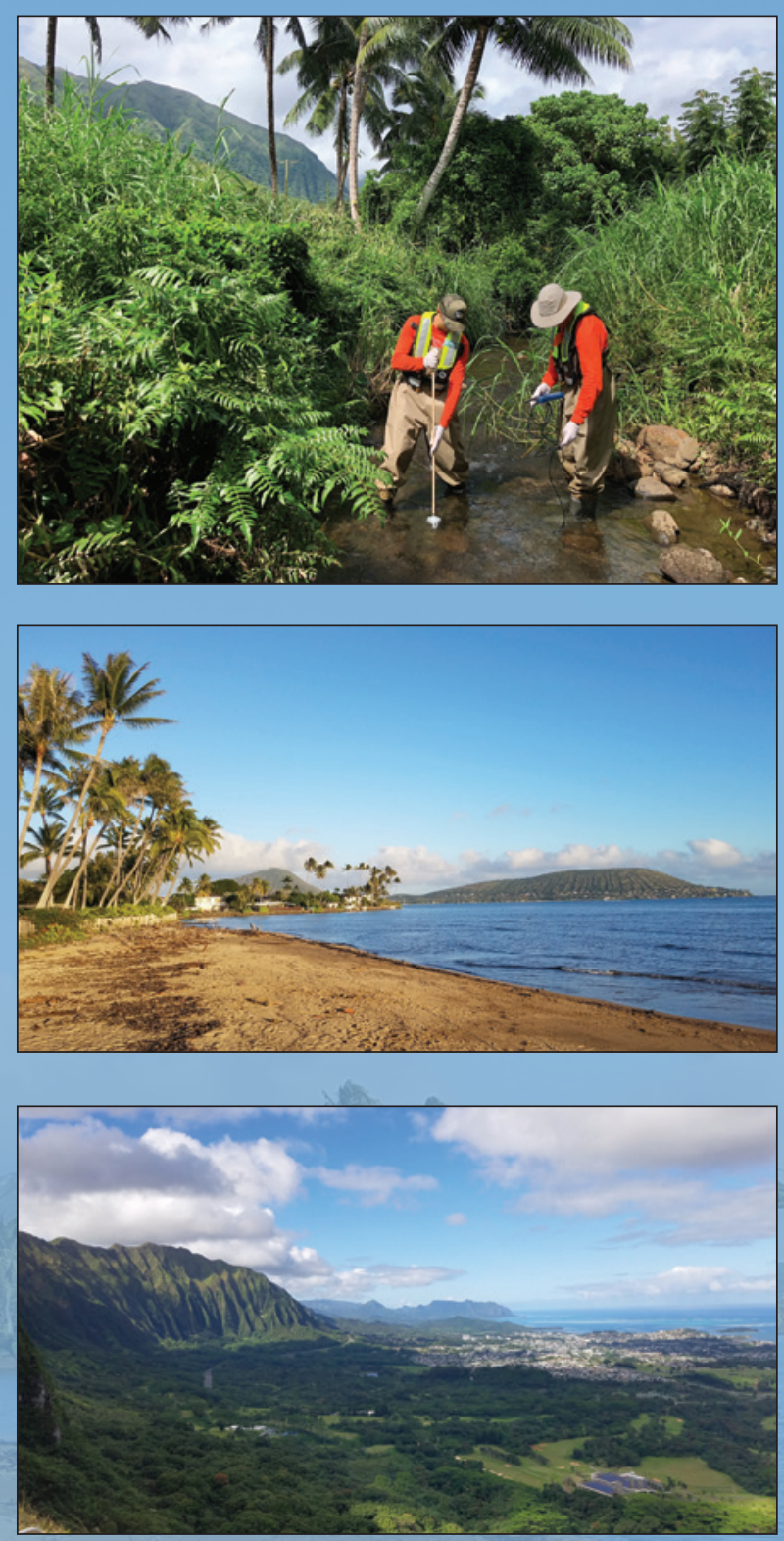

Scientific Investigations Report 2020-5112

U.S. Department of the Interior U.S. Geological Survey 
Cover: Top, U.S. Geological Survey (USGS) personnel collecting water sample from Waihe'e Stream, near Kahalu'u, O‘ahu, Hawai'i; photograph by USGS, October 2017. Middle, Hawai'i Department of Health Clean Water Branch monitoring site, near Niu Beach, O'ahu, Hawai'i; photograph by Adam Johnson (USGS), December 2018. Bottom, watershed near Kāne‘ohe, O‘ahu, Hawai'i; photograph by Adam Johnson (USGS), January 2019. 


\section{Source-Tracking Approach for Detecting and Identifying Sources of Wastewater in Waters of Hawai'i}

By Adam G. Johnson

Prepared in cooperation with the State of Hawai'i Department of Health Clean Water Branch

Scientific Investigations Report 2020-5112

U.S. Department of the Interior

U.S. Geological Survey 


\title{
U.S. Department of the Interior \\ DAVID BERNHARDT, Secretary
}

\author{
U.S. Geological Survey \\ James F. Reilly II, Director
}

U.S. Geological Survey, Reston, Virginia: 2020

For more information on the USGS - the Federal source for science about the Earth, its natural and living resources, natural hazards, and the environment-visit https://www.usgs.gov or call 1-888-ASK-USGS.

For an overview of USGS information products, including maps, imagery, and publications, visit https://store.usgs.gov.

Any use of trade, firm, or product names is for descriptive purposes only and does not imply endorsement by the U.S. Government.

Although this information product, for the most part, is in the public domain, it also may contain copyrighted materials as noted in the text. Permission to reproduce copyrighted items must be secured from the copyright owner.

Suggested citation:

Johnson, A.G., 2020, Source-tracking approach for detecting and identifying sources of wastewater in waters of Hawai'i: U.S. Geological Survey Scientific Investigations Report 2020-5112, 53 p., https://doi.org/10.3133/ sir20205112.

ISSN 2328-0328 (online) 


\section{Acknowledgments}

The author acknowledges Delwyn Oki (U.S. Geological Survey [USGS]), Charles (Chip) Hunt, Jr. (formerly with USGS, now retired), and Larry Barber (USGS) for reviewing drafts of this report and providing comments. Thanks to staff presently or formerly with the State of Hawai $i$ Department of Health Clean Water Branch. 


\section{Contents}

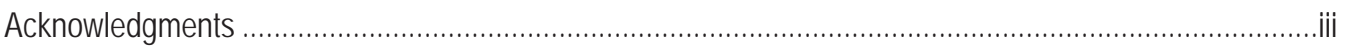

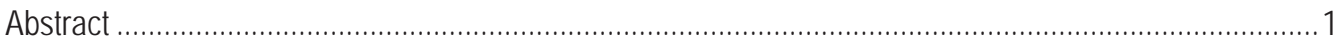

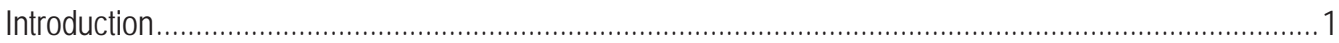

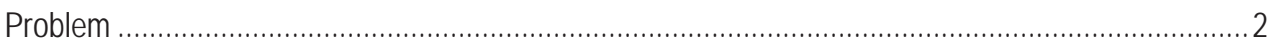

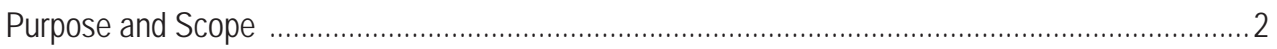

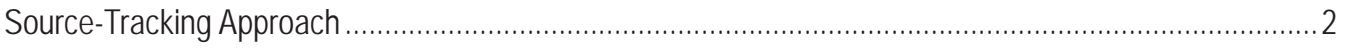

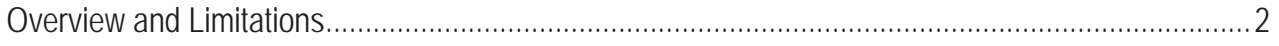

Gathering Background Information..................................................................................... 2

Identifying Potential Sources of Nutrients and Bacteria..................................................... 4

Identifying Potential Mechanisms that Transport Nutrients and Bacteria from Watersheds to

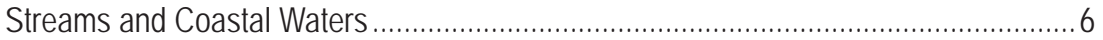

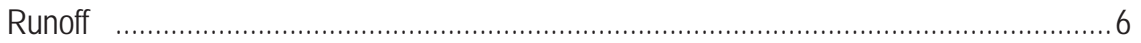

Groundwater Discharge and Dry-Weather Streamflow............................................. 6

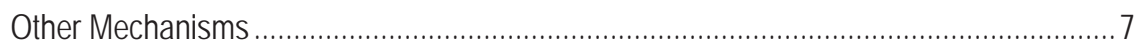

Identifying Source Waters Relevant to the Study Area ……............................................

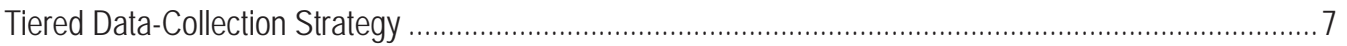

Trolling-Instrument Surveys of Surface-Water Properties ……...............................................

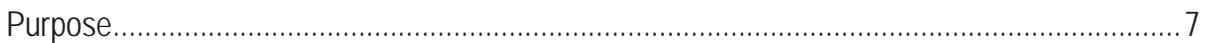

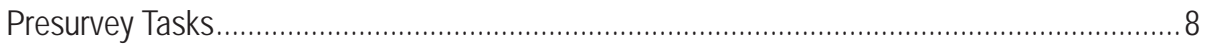

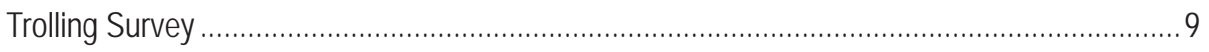

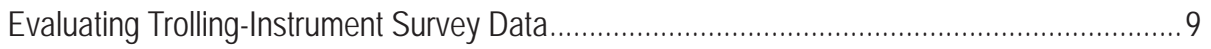

Reconnaissance Sampling for Optical Brighteners and Specific Conductance................................ 9

Selecting and Inspecting Reconnaissance-Sampling Sites .............................................. 10

Selecting Reconnaissance-Sampling Periods and Conditions ............................................. 10

Selecting Reconnaissance-Sample-Collection Methods and Equipment ...............................10

Preparing for Sample Collection for Optical-Brightener Testing and Specific Conductance

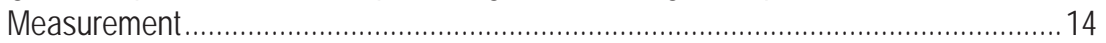

Collecting Water Samples for Optical-Brightener Testing and Specific Conductance

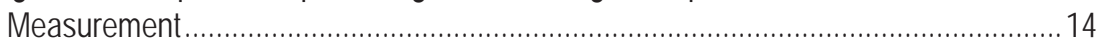

Determining the Presence or Absence of Optical Brighteners............................................ 14

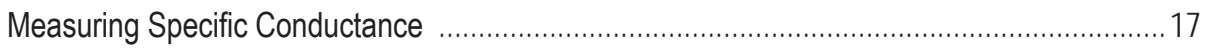

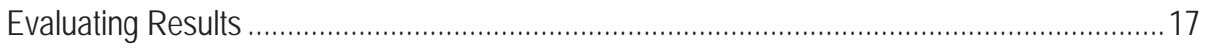

Sampling at Targeted Sites for Multiple Chemical Tracers of Wastewater ......................................17

Selecting Chemical Tracers, Targeted-Sampling Sites, and Sampling Period......................... 17

Selecting Sample-Collection Methods and Equipment ………........................................ 19

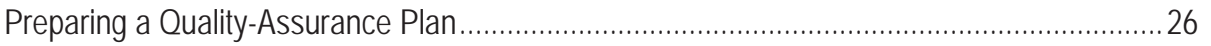

Planning for the Collection and Analysis of Quality-Control Samples .............................26

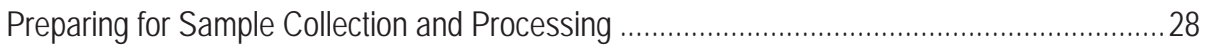

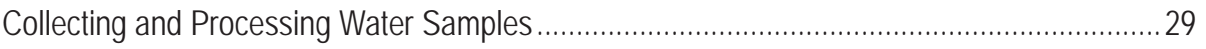

Evaluating Laboratory Results of Chemical Tracers of Wastewater.................................................. 30

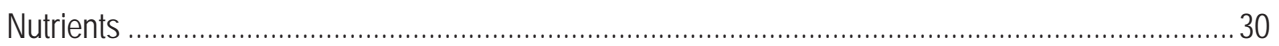

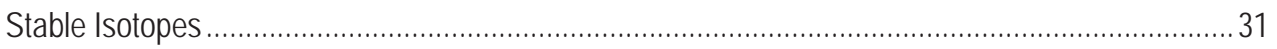

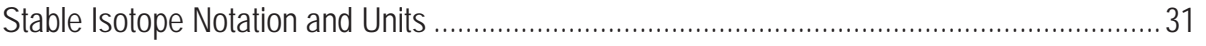

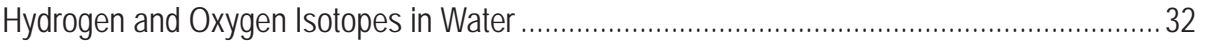


Nitrogen and Oxygen Isotopes in Dissolved Nitrate ..................................................... 36

Organic-Waste Compounds and Human-Use Pharmaceutical Compounds ................................. 37

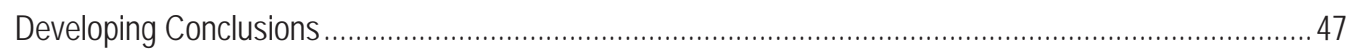

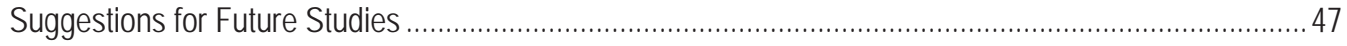

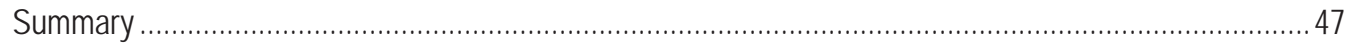

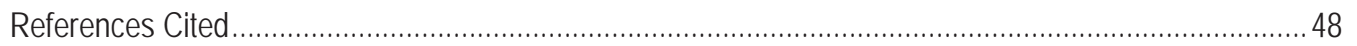

\section{Figures}

1. Conceptual diagram showing source-tracking approach for detecting and identifying wastewater in waters of Hawai'

2. Map showing locations of source-tracking studies conducted in Hawai'i by State of Hawai'i Department of Health Clean Water Branch and U.S. Geological Survey, 2004-17................... 4

3. Photographs showing wading platform and kayaking platform used for trolling-instrument surveys in estuaries and coastal ocean waters .

4. Photograph of handmade, weighted bottle holder that can be used to collect nonisokinetic stream samples from bridges.....

5. Photographs showing unattended equipment used to collect samples at stream sites during

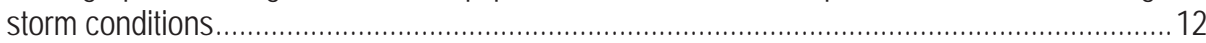

6. Photographs showing sampling techniques and equipment......................................................13

7. Examples of lists of sampling equipment used to collect reconnaissance water samples at different types of sites.

8. Examples of lists of equipment used to test water samples for optical brighteners and specific conductance

9. Lists of clean hands/dirty hands techniques to follow when collecting water-quality samples to be analyzed for chemical tracers of wastewater.

10. Mixing plot used to determine whether water samples collected near Māhā'ulepū, Kaua'i, are enriched or depleted in nitrate, relative to mixing line between ambient freshwater and ocean water

11. Plots of $\delta^{2} \mathrm{H}$ versus $\delta^{18} \mathrm{O}$ compositions of water samples collected at different groups of sites on Kaua'i, O'ahu, Maui, and Hawai'i Island during 2000-17 .....

12. Plot of $\delta^{2} \mathrm{H}$ in water versus specific conductance for water samples collected near Kīhei, Maui, in 2004 and 2008

13. Graph showing nitrate source classification that is based on nitrogen and oxygen stable-isotope compositions of dissolved nitrate.

14. Occurrence of organic-waste compounds in groundwater and surface-water samples collected at 14 general locations in Hawai'i during 2004-17

15. Occurrence of pharmaceutical compounds in groundwater and surface-water samples collected at 14 general locations in Hawai'i during 2007-17

16. Map showing general locations of sites on Kaua'i, Hawai'i, where groundwater and surfacewater samples were collected during 2012-15 and then analyzed for organic-waste compounds and pharmaceutical compounds .....

17. Map showing general locations of sites on O'ahu, Hawai'i, where groundwater and surfacewater samples were collected during 2004-17 and then analyzed for organic-waste compounds, pharmaceutical compounds, or both

18. Maps showing general locations of sites where groundwater and surface-water samples were collected on Maui and on Hawai'i Island, Hawai'i, during 2004-12 and 2007-09, respectively, and then analyzed for organic-waste compounds and pharmaceutical compounds 


\section{Tables}

1. General locations and descriptions of source-tracking studies conducted in Hawai'i by the State of Hawai'i Department of Health Clean Water Branch and the U.S. Geological Survey, 2004-17...

2. Worksheet template for recording fluorescence measurements and determining the presence or absence of optical brighteners in water samples

3. Examples of laboratory methods capable of analyzing water for selected chemical tracers of wastewater

4. Organic-waste compounds analyzed in water samples by the U.S. Geological Survey National Water Quality Laboratory.

5. Human-use pharmaceutical compounds analyzed in filtered-water samples by the U.S. Geological Survey National Water Quality Laboratory.

\section{Conversion Factors}

U.S. customary units to International System of Units

\begin{tabular}{lcl}
\hline \multicolumn{1}{c}{ Multiply } & \multicolumn{1}{c}{ By } & \multicolumn{1}{c}{ To obtain } \\
\hline inch (in.) & 25.4 & millimeter $(\mathrm{mm})$ \\
foot (ft) & 0.3048 & meter $(\mathrm{m})$ \\
mile (mi) & 1.609 & kilometer $(\mathrm{km})$ \\
\hline \multicolumn{3}{c}{ Area } \\
\hline square foot $\left(\mathrm{ft}^{2}\right)$ & 0.09290 & square meter $\left(\mathrm{m}^{2}\right)$ \\
square inch $\left(\mathrm{in}^{2}\right)$ & 6.452 & square centimeter $\left(\mathrm{cm}^{2}\right)$ \\
square mile $\left(\mathrm{mi}^{2}\right)$ & 2.590 & square kilometer $\left(\mathrm{km}^{2}\right)$ \\
\hline & \multicolumn{2}{c}{ Volume } \\
\hline ounce, fluid (fl. oz) & 0.02957 & liter $(\mathrm{L})$ \\
gallon (gal) & 3.785 & liter $(\mathrm{L})$ \\
gallon (gal) & 0.003785 & cubic meter $\left(\mathrm{m}^{3}\right)$ \\
cubic inch (in $\left.{ }^{3}\right)$ & 0.01639 & liter $(\mathrm{L})$ \\
cubic foot $\left(\mathrm{ft}^{3}\right)$ & 0.02832 & cubic meter $\left(\mathrm{m}^{3}\right)$ \\
\hline
\end{tabular}




\section{Conversion Factors-Continued}

International System of Units to U.S. customary units

\begin{tabular}{|c|c|c|}
\hline Multiply & By & To obtain \\
\hline \multicolumn{3}{|c|}{ Length } \\
\hline millimeter (mm) & 0.03937 & inch (in.) \\
\hline meter (m) & 3.281 & foot (ft) \\
\hline kilometer (km) & 0.6214 & mile (mi) \\
\hline \multicolumn{3}{|c|}{ Area } \\
\hline square meter $\left(\mathrm{m}^{2}\right)$ & 10.76 & square foot $\left(\mathrm{ft}^{2}\right)$ \\
\hline square centimeter $\left(\mathrm{cm}^{2}\right)$ & 0.1550 & square inch $\left(\mathrm{ft}^{2}\right)$ \\
\hline square kilometer $\left(\mathrm{km}^{2}\right)$ & 0.3861 & square mile $\left(\mathrm{mi}^{2}\right)$ \\
\hline \multicolumn{3}{|c|}{ Volume } \\
\hline liter (L) & 33.81402 & ounce, fluid (fl. oz) \\
\hline liter (L) & 0.2642 & gallon (gal) \\
\hline cubic meter $\left(\mathrm{m}^{3}\right)$ & 264.2 & gallon (gal) \\
\hline liter (L) & 61.02 & cubic inch $\left(\right.$ in $\left.^{3}\right)$ \\
\hline cubic meter $\left(\mathrm{m}^{3}\right)$ & 35.31 & cubic foot $\left(\mathrm{ft}^{3}\right)$ \\
\hline
\end{tabular}

Temperature in degrees Celsius $\left({ }^{\circ} \mathrm{C}\right)$ may be converted to degrees Fahrenheit $\left({ }^{\circ} \mathrm{F}\right)$ as follows:

$$
{ }^{\circ} \mathrm{F}=\left(1.8 \times{ }^{\circ} \mathrm{C}\right)+32 .
$$

Temperature in degrees Fahrenheit $\left({ }^{\circ} \mathrm{F}\right)$ may be converted to degrees Celsius $\left({ }^{\circ} \mathrm{C}\right)$ as follows:

$$
{ }^{\circ} \mathrm{C}=\left({ }^{\circ} \mathrm{F}-32\right) / 1.8 \text {. }
$$

\section{Supplemental Information}

Specific conductance is given in microsiemens per centimeter at 25 degrees Celsius $\left(\mu \mathrm{S} / \mathrm{cm}\right.$ at $\left.25^{\circ} \mathrm{C}\right)$. 


\section{Abbreviations}

$\begin{array}{ll}\text { AIR } & \text { atmospheric air } \\ \text { CWB } & \text { State of Hawai'i Department of Health Clean Water Branch } \\ \text { GIS } & \text { geographic information system } \\ \text { GPS } & \text { global positioning system } \\ \text { L } & \text { liter(s) } \\ \text { mg/L } & \text { milligram(s) per liter } \\ \text { min } & \text { minute(s) } \\ \text { mL } & \text { milliliter(s) } \\ \text { MWL } & \text { meteoric-water line } \\ \text { NCEI } & \text { NOAA's National Centers for Environmental Information } \\ \text { ng/L } & \text { nanogram(s) per liter } \\ \text { nm } & \text { nanometer(s) } \\ \text { NOAA } & \text { National Oceanic and Atmospheric Administration } \\ \text { NWIS } & \text { USGS National Water Information System } \\ \text { NWQL } & \text { USGS National Water Quality Laboratory } \\ \text { OSDS } & \text { on-site disposal system } \\ \text { PAH } & \text { polycyclic aromatic hydrocarbon } \\ \text { per mil [\%] } & \text { parts per thousand } \\ \text { QC } & \text { quality control } \\ \text { RSIL } & \text { USGS Reston Stable Isotope Laboratory } \\ \text { SC } & \text { specific conductance } \\ \text { USGS } & \text { U.S. Geological Survey } \\ \text { VSMOW } & \text { Vienna Standard Mean Ocean Water } \\ \mu \text { g/L } & \text { microgram(s) per liter } \\ \mu \text { L } & \text { microliter(s) } \\ & \end{array}$




\title{
Source-Tracking Approach for Detecting and Identifying Sources of Wastewater in Waters of Hawai'i $i$
}

\author{
By Adam G. Johnson
}

\section{Abstract}

Elevated concentrations of nutrients and the fecalindicator bacteria enterococci are occasionally detected in Hawai'i's surface waters by the State of Hawai'i Department of Health Clean Water Branch. Management efforts to improve the water quality of surface waters are complicated by the fact that nutrients and enterococci can originate from several sources, including wastewater, animal waste, and soils. Wastewater often is the suspected source of nutrients and bacteria, but the source may not always be unequivocally identifiable from the Clean Water Branch's routine monitoring efforts. This report-prepared in cooperation with the State of Hawai'i Department of Health Clean Water Branch - describes a source-tracking approach for Hawai' $i$ that is meant to help investigators determine whether wastewater is present in the environment and where wastewater might be originating, if it is present. Wastewater sources include domestic wastewater entering the environment through on-site disposal systems and municipal wastewater entering the environment through leaky sewer systems or injection-well disposal systems. The source-tracking approach relies on the use of field-measured water properties and multiple chemical tracers of wastewater, including optical brighteners, nutrients, hydrogen and oxygen isotopes in water, nitrogen and oxygen isotopes in nitrate, organic waste compounds, and human-use pharmaceutical compounds. The source-tracking approach proposes the following sequence of steps for investigators to execute: (1) gather background information on the study area, (2) conduct trolling-instrument surveys of physical properties of surface water and identify groundwater-discharge locations, (3) collect water samples at reconnaissance sites and analyze the samples for detergent optical brighteners and specific conductance, (4) collect water samples at targeted sites and have appropriate laboratories analyze the samples for chemical tracers of wastewater, and (5) evaluate analytical results for chemical tracers of wastewater and conclude whether wastewater is present in sampled waters. The conclusions can guide management and stakeholder efforts to protect and improve the quality of Hawai'i's water resources.

\section{Introduction}

The State of Hawai'i Department of Health Clean Water Branch $(\mathrm{CWB})$ is responsible for protecting and restoring the ecosystem health of Hawai 'i's surface waters for marine life and wildlife (State of Hawai' $i$, 2017). The CWB assesses the ecosystem health of surface waters by monitoring several nutrients and other properties such as turbidity, total suspended solids, and chlorophyll $a$. Waters that have concentrations of these properties that exceed applicable State of Hawai'i (2014) water-quality standards are considered impaired. In a recent assessment (State of Hawai ${ }^{i} i$, 2017) of the ecosystem health of Hawai'i's surface waters, results of nutrient monitoring in waters of 24 coastal watersheds indicated that 10 of the 24 assessed watersheds were impaired for one or more nutrients.

The CWB also is responsible for notifying the public about which surface waters in Hawai'i may contain harmful pathogens that can sicken people. Pathogens harmful to humans include bacteria and viruses that typically originate from the fecal matter of humans and other warm-blooded animals. People who recreate in fecal-contaminated water risk exposure to pathogens that can cause gastrointestinal illnesses and may lead to diarrhea, nausea, stomach aches, and vomiting. The CWB infers the presence of fecal pathogens in water and associated health risks to humans by monitoring the fecal-indicator bacteria enterococci. The U.S. Environmental Protection Agency (2012) recommended monitoring enterococci to assess potential health risks of pathogens to humans recreating in fresh and marine waters because enterococci concentrations in water impacted by wastewater have been correlated with the risk of humans contracting gastrointestinal illnesses. Currently (2020), enterococci are monitored by the CWB at dozens of sites on Kaua'i, O'ahu, Maui, and Hawai'i Island; most of the sites are near or along the coastlines of these islands. The CWB notifies the public of the potential health risks of recreating in waters that have enterococci levels that exceed the State of Hawai'i (2014) recreational water-quality standards. 


\section{Problem}

Management efforts to improve the water quality of surface waters that have concentrations of nutrients and enterococci bacteria exceeding State of Hawai'i (2014) waterquality standards are complicated by the fact that nutrients and enterococci bacteria can originate from several sources. Potential nutrient sources include wastewater, animal fecal matter, fertilizers applied to agricultural and urban areas, nitrogen-fixing bacteria, decomposition of organic matter, and atmospheric deposition. Enterococci bacteria, prevalent in human fecal matter and wastewater, also are prevalent in the fecal matter of animals present in Hawai 'i's watersheds, including cows, pigs, dogs, cats, chickens, quail, pigeons, rats, and mice (Luther and Fujioka, 2004). Enterococci bacteria also have been found in O'ahu's soils (Hardina and Fujioka, 1991; Goto and Yan, 2011; Byappanahalli and others, 2012) and streams (Viau and others, 2011), and they are capable of colonizing and growing in Hawai'i's soils (Byappanahalli and others, 2012).

Wastewater often is the suspected source of elevated nutrients and enterococci detected in the environment. The presence of wastewater in sampled waters, however, may not be definitively known from the CWB's routine monitoring efforts. The ability to determine the presence of wastewater and its source is needed to develop contaminant-reduction strategies and actions.

\section{Purpose and Scope}

This report - prepared in cooperation with the State of Hawai'i Department of Health Clean Water Branch - describes an approach for detecting wastewater in environmental waters. Wastewater sources include domestic wastewater entering the environment through on-site disposal systems (OSDSs) and municipal wastewater entering the environment through leaky sewer systems or injection-well disposal systems. The approach is limited to physical and chemical indicators of wastewater. The report can serve as a reference guide that can direct the efforts of investigators in future instances where elevated nutrients and fecal-indicator bacteria are detected and knowledge of the presence or absence of wastewater is needed. The report includes descriptions of data-collection and data-evaluation procedures.

\section{Source-Tracking Approach}

The source-tracking approach is meant to help investigators determine whether wastewater is present in water in the environment and where wastewater might be originating. The source-tracking approach proposes the following sequence of steps: (1) gathering background information on the study area, (2) conducting trolling-instrument surveys of physical properties of surface water and identifying groundwater-discharge locations, (3) collecting water samples at reconnaissance sites and analyzing the samples for detergent optical brighteners and specific conductance (SC), (4) collecting water samples at targeted sites and having appropriate laboratories analyze the samples for chemical tracers of wastewater, and (5) evaluating analytical results for chemical tracers of wastewater and concluding whether wastewater is present in sampled waters (fig. 1). The conclusions developed by investigators can guide management and stakeholder efforts to protect the health of recreational water users and aquatic organisms, protect the quality of Hawai'i's water resources and aquatic environments, and remediate water-quality problems.

The strategy and procedures of the source-tracking approach described in this report, which were cooperatively developed by the CWB and U.S. Geological Survey (USGS), were applied to various degrees during several studies in Hawai' 'i from 2004 to 2017 (fig. 2; table 1). Studies at Kīhei and Lahaina on Maui used the source-tracking approach to detect treated wastewater effluent in coastal groundwater and in coastal ocean water seaward of wells in which treated wastewater was injected at depth into a coastal aquifer. Similarly, the study at Kealakehe on Hawai' $i$ Island used the approach to detect treated wastewater effluent in coastal groundwater and in an ocean harbor seaward of an open pit in a lava flow where treated wastewater was discharged. Most of the remaining studies listed in table 1 used the source-tracking approach with the intent to determine whether groundwater, streams, estuaries, and coastal ocean water contained wastewater that may have leached or leaked from cesspools, septic systems, or sewer lines.

\section{Overview and Limitations}

The source-tracking approach presented here relies on physical and chemical tracers of wastewater. Highly diagnostic wastewater tracers are nitrogen and oxygen isotopes in dissolved nitrate, human-use pharmaceutical compounds, and organic-waste compounds. Currently (2020), the approach does not include the use of introduced tracers such as dyes. It also does not include the testing of samples for genetic material, which is the foundation of microbial sourcetracking methods (see, for example, Kirs and others, 2016) that could be considered to complement methods that are part of the source-tracking approach. The approach does not include techniques to distinguish between different types of nonwastewater nutrient sources such as fertilizers and animal fecal matter. Additional limitations of the source-tracking approach are described throughout this report.

\section{Gathering Background Information}

The first step of the source-tracking approach is to gather existing background information that will help to identify potential sources of nutrients and bacteria in a watershed and areas adjacent to the sites of concern. By gathering background information, investigators can identify (1) potential mechanisms that can transport nutrients and bacteria from watershed landscapes to streams, beaches, and coastal waters, and (2) source waters relevant to the study area. Background information will help to define the scope of 


\section{Detecting and identifying wastewater}

1. Gather background information on the study area

Identify potential

- sources of fecal-indicator bacteria and nutrients

- mechanisms, such as runoff and groundwater discharge, that can transport bacteria and nutrients from watershed sources to streams and coastal ocean waters

- source waters, such as ambient freshwater, community tap water, and ocean water

2. Conduct trolling-instrument surveys of physical properties of surface water and identify groundwater-discharge locations
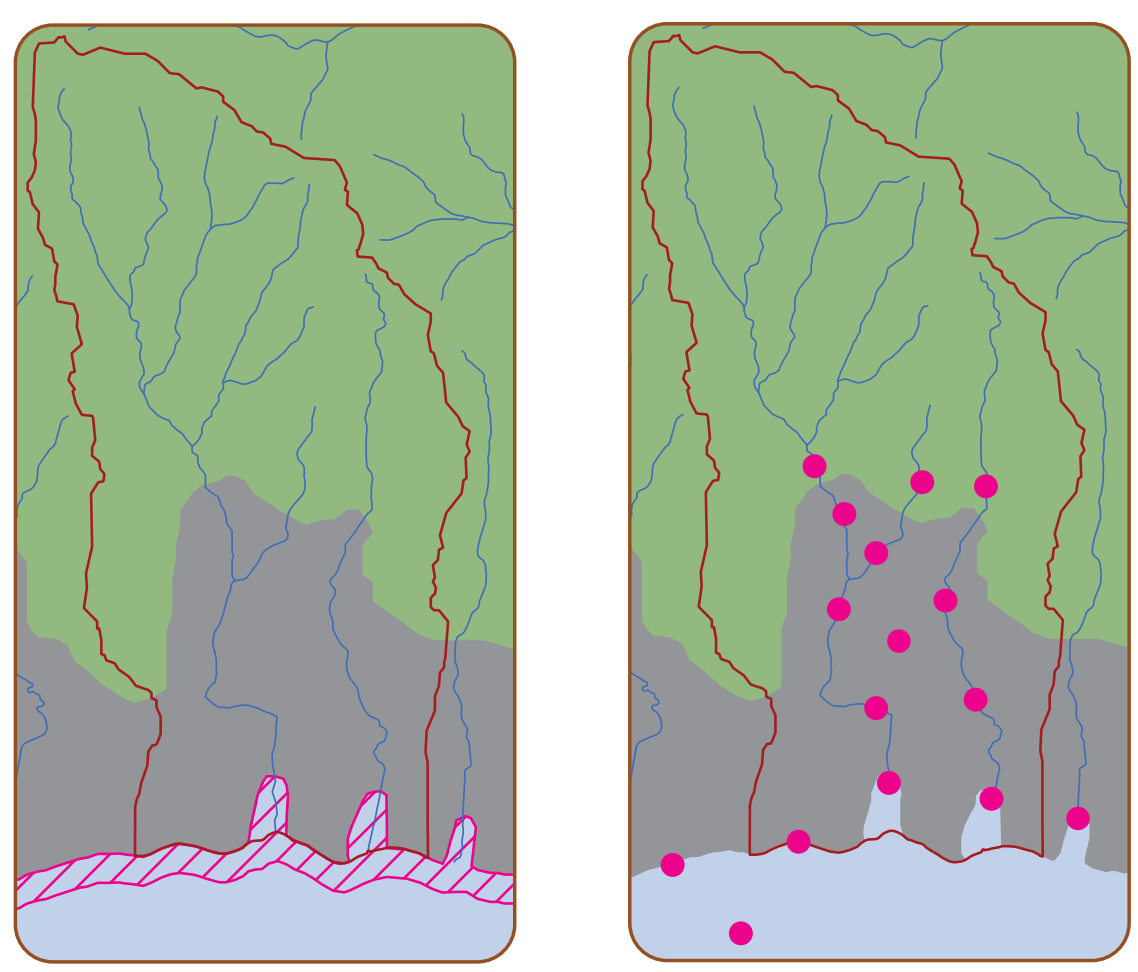

5. Evaluate analytical results for chemical tracers of wastewater and conclude whether wastewater is present in sampled waters

Chemical tracers include

- nutrients

- hydrogen and oxygen isotopes in water

- nitrogen and oxygen isotopes in nitrate

- organic-waste compounds

- pharmaceutical compounds
3. Collect water samples at reconnaissance sites and analyze samples for detergent optical brighteners and specific conductance

4. Collect water samples at targeted sites and have appropriate laboratories analyze samples for chemical tracers of wastewater

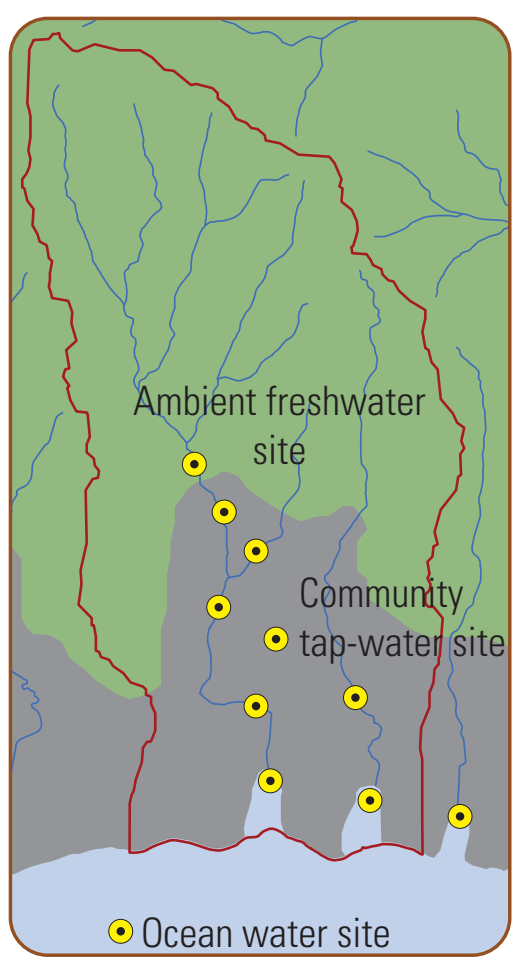

\section{EXPLANATION}

Forested and undeveloped areas Developed areas

Coastal ocean and estuaries

VIA Trolling-instrument survey area

_ General boundary of study area

$\sim$ Stream

- Reconnaissance site

- Targeted site

Maps shown are hypothetical and are meant to illustrate an example of the data-collection efforts of the source-tracking approach

Figure 1. Conceptual diagram showing source-tracking approach for detecting and identifying wastewater in waters of Hawai`i. 


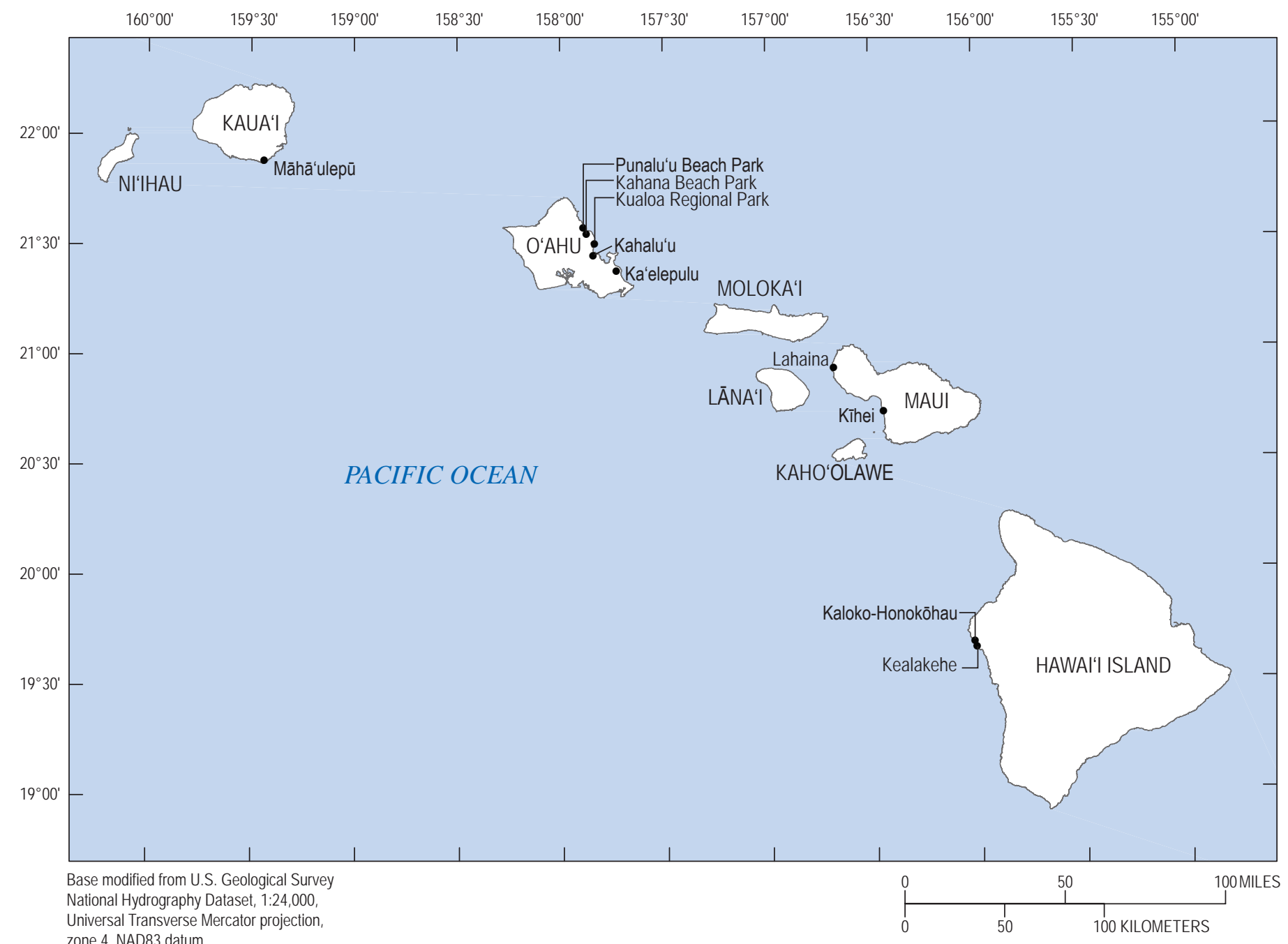

zone 4 NAD83

Figure 2. Map showing locations of source-tracking studies conducted in Hawai ‘ i by State of Hawai $i$ Department of Health Clean Water Branch and U.S. Geological Survey, 2004-17.

subsequent data-collection efforts and will provide context that investigators can refer to when they evaluate water-sample results and develop conclusions.

\section{Identifying Potential Sources of Nutrients and Bacteria}

For the source-tracking approach, investigators can compile an inventory of potential sources of enterococci bacteria and nutrients (nitrogen and phosphorus) within and near the study area. This inventory can be compiled after a watershed-contaminant sanitary survey, similar to that described by Tetra Tech, Inc. (2004), is conducted. Nutrients and bacteria in the environment may originate from a variety of active and inactive sources, such as fertilizers applied to former croplands.

Wastewater and animal fecal matter are two sources of nutrients and bacteria. Wastewater can enter the environment from (1) homes and buildings that have OSDSs such as cesspools and septic systems, (2) wastewater-injection wells, (3) leaks from sewer lines, (4) leaks and spills from wastewater collection and treatment facilities, and (5) illegal dumping. Locations of OSDSs in Hawai' $i$ and estimates of their wastewater-effluent discharge rates can be found in Whittier and El-Kadi $(2009,2014)$. Animals that may be present in a study area include (1) livestock at farms, pastures, and other operations, (2) domestic animals in residential areas, parks, and beaches, and (3) wild animals, which can reside in and move about all parts of a study area.

Synthetic fertilizers are a source of nutrients, and organic fertilizers, depending on their composition, are a source of nutrients and potentially a source of bacteria. Areas where fertilizers are applied include agricultural plots, golf courses, and residential areas. Investigators can develop a general idea of how widespread these areas are in a watershed by examining 
Table 1. General locations and descriptions of source-tracking studies conducted in Hawai'i by the State of Hawaii i Department of Health Clean Water Branch and the U.S. Geological Survey, 2004-17.

[See figure 2 for locations of studies. Abbreviation: USGS, U.S. Geological Survey]

\begin{tabular}{|c|c|c|c|}
\hline General study location & $\begin{array}{l}\text { Sample-collection } \\
\text { year(s) }\end{array}$ & One question that study aimed to answer & $\begin{array}{l}\text { USGS report(s) describing } \\
\text { study results }\end{array}$ \\
\hline Kīhei, Maui & 2004, 2008-09 & $\begin{array}{l}\text { Can treated wastewater effluent that is injected at } \\
\text { depth into the coastal aquifer be detected in coastal } \\
\text { groundwater and nearshore ocean water? }\end{array}$ & $\begin{array}{l}\text { Hunt (2007); Hunt and } \\
\text { Rosa (2009) }\end{array}$ \\
\hline Lahaina, Maui & 2006, 2008 & $\begin{array}{l}\text { Can treated wastewater effluent that is injected at } \\
\text { depth into the coastal aquifer be detected in coastal } \\
\text { groundwater and nearshore ocean water? }\end{array}$ & Hunt and Rosa (2009) \\
\hline Kualoa Regional Park, O‘ahu & 2007 & $\begin{array}{l}\text { Is wastewater a source of high enterococci counts detected } \\
\text { in nearshore ocean waters? }\end{array}$ & None \\
\hline $\begin{array}{l}\text { Kahana Beach Park and } \\
\text { Punalu'u Beach Park, O`ahu }\end{array}$ & 2007 & $\begin{array}{l}\text { Is wastewater a source of high enterococci counts detected } \\
\text { in nearshore ocean waters? }\end{array}$ & None \\
\hline $\begin{array}{l}\text { Kaloko-Honokōhau, Hawai`i } \\
\text { Island }^{1}\end{array}$ & 2009 & $\begin{array}{l}\text { What are the baseline (2009) water-quality conditions of } \\
\text { surface water and groundwater? }\end{array}$ & Hunt (2014) \\
\hline Māhā'ulepū, Kaua‘i & 2015 & $\begin{array}{l}\text { Is wastewater a source of high enterococci counts detected } \\
\text { in nearshore ocean waters? }\end{array}$ & None \\
\hline Kahalu‘u, O`ahu & 2017 & $\begin{array}{l}\text { Is wastewater a source of high enterococci counts detected } \\
\text { in nearshore ocean waters? }\end{array}$ & None \\
\hline
\end{tabular}

\footnotetext{
${ }^{1}$ Study at Kaloko-Honokōhau on Hawai'i Island was conducted by USGS in cooperation with National Park Service.
}

recent aerial imagery, for example in Google Earth (google. com/earth). Historical aerial imagery also can be viewed in Google Earth, and this imagery may reveal relevant land-use practices such as sugarcane and pineapple cultivation that are not currently active but were in the past. More quantitative land-use analyses can be completed after obtaining geospatial datasets of land use and then examining these datasets in a geographic information system (GIS). For example, a geospatial dataset of 2015 agriculture in Hawai' $i$ was developed by Melrose and others (2016). Geospatial datasets of developed areas and other types of land cover in Hawai' $i$ have been produced by the National Ocean and Atmospheric Administration's Coastal Change Analysis Program (https://coast.noaa. gov/digitalcoast/data/ccapregional.html) and by the USGS LANDFIRE Program (https://www.landfire.gov/index.php). A dataset of land cover and land use in Hawai' $i$ in 1976 is available from State of Hawaii (1976). Investigators also could ask the State of Hawai'i Department of Agriculture and agricultural managers for more specific information on fertilizer applications in specific agricultural areas.

Nitrogen is fixed naturally from the atmosphere by bacteria contained in root nodules of some plants, including legumes. Nitrogen-fixing plants found in Hawai' $i$ include (1) the nonnative tree Falcataria moluccana (peacocksplume, also known as albizia) that has invaded lowland forests (Asner and others, 2008), (2) the dryland scrub trees Prosopis pallida (kiawe or mesquite) and Leucaena leucocephala (koa haole or lead tree) found in arid areas (Kay and others, 1977), and (3) Morella faya (firetree) (Vitousek and others, 1987; Asner and others, 2008). Decomposition of vegetation litter and soil organic matter releases nitrogen and phosphorus to soils and water. For four streams on Hawai'i Island, 
Source-Tracking Approach for Detecting and Identifying Sources of Wastewater in Waters of Hawai' $i$

Wiegner and others (2013) determined that nitrate plus nitrite concentrations were substantially greater in stream reaches that were downstream from F. moluccana stands than in stream reaches above the stands.

Nitrogen and phosphorus also are added to the Hawaiian Islands by atmospheric deposition. For example, phosphorus is deposited in wind-blown dust from Asia (Chadwick and others, 1999; Kurtz and others, 2001), and nitrogen is added by rainfall and fog (Carrillo and others, 2002) and by deposition of marine aerosols (Cornell and others, 2001). Phosphorus also is added to soils during the chemical breakdown and weathering of minerals in volcanic rock in Hawai' $i$. Other potential nutrient sources in watersheds include solid-waste facilities and reclaimed water applied as irrigation.

Enterococci bacteria have been found in O'ahu's soils (Hardina and Fujioka, 1991; Goto and Yan, 2011; Byappanahalli and others, 2012), and they also are capable of colonizing and growing in soils in the Hawaiian Islands (Byappanahalli and others, 2012). Results of laboratory experiments by Desmarais and others (2002) showed regrowth of enterococci and Escherichia coli in sediments in response to the addition of more sterile sediment, indicating that enterococci are capable of multiplying in soil environments. Because soil commonly is transported to streams during periods of rainfall, the soil represents a natural source of enterococci in Hawaiian streams. Oshiro and Fujioka (1995) found high concentrations of fecal-indicator bacteria in beach sand at Hanauma Bay, $\mathrm{O}^{\prime} \mathrm{ahu}$, and suggested that the pigeon excreta, mongoose excreta, and land runoff were sources of fecal-indicator bacteria in beach sand and water.

\section{Identifying Potential Mechanisms that Transport Nutrients and Bacteria from Watersheds to Streams and Coastal Waters}

Mechanisms that transport nutrients and bacteria from watersheds to streams and coastal waters include runoff, dryweather streamflow, and coastal groundwater discharge. Runoff caused by storms is intermittent, whereas dry-weather streamflow and coastal groundwater discharge can be persistent.

\section{Runoff}

Runoff, which occurs after substantial rainfall, can transport various nutrient and bacteria source materials from different parts of the watershed (for example, (1) fecal matter of wild animals from forests and undeveloped areas, (2) fecal matter of livestock in grazing areas, (3) fertilizer nutrients from agricultural areas, and (4) enterococci bacteria present in soils from all parts of a watershed) to streams and coastal waters.

Runoff also is an important nutrient- and bacteriatransport mechanism in urban and residential areas, which usually contain impervious surfaces such as rooftops, roads, parking lots, stormwater conveyances, and other paved surfaces. Urban and residential areas also can contain nutrients from fertilizers that have been applied to landscapes and from fecal matter from pets, birds, rodents, and other animals. Fertilizers and animal fecal matter deposited on or near impervious surfaces can be rapidly conveyed by runoff to dry wells and storm-drain systems that then empty into streams and coastal waters. In contrast, nutrients and bacteria in runoff that passes through pervious surfaces can settle and sorb to soil surfaces, and the nutrients potentially can be used by vegetation. For example, Mallin and others (2000) found that bacterial contamination of creeks in several urban watersheds along the southeastern coast of North Carolina was positively correlated with the percentage of impervious area in the watershed, and they suspected that dogs and cats were a major fecal-pollution source in the watersheds. Similarly, Young and Thackston (1999) observed in several drainage basins in Tennessee that bacteria counts were lower in storm runoff from basins that have relatively sparse development than those in basins that have relatively dense development, greater impervious coverage, and a large population of dogs.

Investigators can compare rainfall and streamflow records with records of bacteria counts to determine whether the elevated bacteria counts are a wet-weather phenomenon, a dry-weather phenomenon, or a phenomenon unrelated to rainfall. Investigators also can evaluate whether elevated bacteria counts and nutrient concentrations at monitoring sites might be affected by runoff by evaluating records of rainfall and streamflow measurements from within or near their study area. Specifically, investigators ideally would examine the relation between the timing of (1) elevated bacteria counts at monitoring sites and (2) substantial rainfall and high streamflow events within or near the study area. Records of rainfall in Hawai' $i$ can be obtained from NOAA's National Centers for Environmental Information (NCEI) website (https:// www.ncdc.noaa.gov/), and records of rainfall and streamflow (stream discharge) in Hawai' $i$ can be obtained from USGS's National Water Information System (NWIS) website (U.S. Geological Survey [USGS], 2016).

\section{Groundwater Discharge and Dry-Weather Streamflow}

Nutrients and bacteria from various watershed sources can leach into groundwater, which then can discharge to streams, beaches, and coastal waters. For example, wastewater can leach into groundwater from cesspools, leaking septic systems, leaking sewer lines, and illegal dumping, and wastewater also can be injected into groundwater wells. Nutrients and bacteria from animal waste, fertilizers, and soils also can leach into groundwater.

Streamflow during dry-weather conditions typically is sustained by groundwater discharge. Dry-weather streamflow, as well as coastal groundwater discharge, can be persistent mechanisms that transport watershed nutrients and bacteria to receiving waters. For example, Viau and others (2011) found enterococci in all 22 streams that they sampled on $\mathrm{O}^{\prime} \mathrm{ahu}$; the samples were collected during relatively dry weather conditions only. 


\section{Other Mechanisms}

Wastewater can reach streams or coastal waters from spills, illegal dumping, and storm sewers that are unintentionally or intentionally (illicitly) connected to sanitary sewers. Sanitary sewers and septic systems can be affected by storm-related overflows. Beachgoers and their pets can directly deposit excreta on beaches and in coastal waters. Other potential mechanisms include resuspension of streambed sediments or coastal sediments that harbor enterococci. For example, Wilson and others (2014) determined that an important source of fecal-indictor bacteria in water at a popular swimming beach in Missouri was sediment that had been contaminated by bird fecal matter and was later resuspended in water by people wading and recreating in the water. Similarly, fecal-indicator bacteria that Oshiro and Fujioka (1995) found in beach sand at Hanauma Bay, O`ahu, a popular beach and snorkeling area, may have been transported to water by waves washing through the sand, as well as by people. Desmarias and others (2002) found elevated counts of fecal-indicator bacteria within surficial sediments along an estuarine riverbank in Florida and suggested that tidal movements and waves could flush the bacteria from the sediments into the river.

\section{Identifying Source Waters Relevant to the Study Area}

The source-tracking approach proposes that investigators identify source waters in their study area because source waters could affect the chemistry of a water sample collected from a site. A source water is defined in this report as a substantial source or reservoir of groundwater, surface water, or wastewater within a study area or watershed. In a typical coastal watershed in Hawai' $i$, two likely source waters would be ambient freshwater and ocean water: ambient freshwater could be represented by groundwater or by streamwater from the inland, mostly undeveloped part of a watershed (fig. 1), and ocean water could be represented by water in the coastal ocean near the watershed or island. The concentrations of chemicals in ambient freshwater and ocean water provide important context to investigators who evaluate chemicaltracer results for water samples collected during sourcetracking efforts.

Treated wastewater effluent that is injected into wells can represent a source water, as was identified by Hunt (2007) and Hunt and Rosa (2009) for CWB-USGS source-tracking efforts on Maui. If sewer lines, cesspools, or septic systems are suspected sources of nutrients and bacteria in the watershed, then community tap water would represent a source water because tap water is the original source of wastewater that flows through sewer lines to wastewater treatment facilities, and it drains into cesspools and septic systems. Reclaimed wastewater that is applied as irrigation is another possible source water.

The source-tracking approach proposes that investigators attempt to identify the presence or absence of wastewater in a watershed on the basis of the physical and chemical properties of water. Water sampled at a given spot in a watershed may be composed predominantly of one source water, or it could be a mixture of two or more source waters. Discernment of a sample's chemical and water origins may be possible if the physical and chemical properties of the sample and its source waters are known.

\section{Tiered Data-Collection Strategy}

After gathering background information, investigators can begin collecting data in the study area. The sourcetracking approach proposes a tiered data-collection strategy consisting of (1) trolling-instrument surveys of surface-water properties, (2) reconnaissance water sampling for optical brighteners and SC, and (3) targeted water sampling for multiple chemical tracers of wastewater (fig. 1).

The three tiers of the data-collection strategy are meant to be executed sequentially to produce an informative dataset at minimal cost. In general, efforts for tiers 1 and 2 are straightforward and can be completed entirely by investigators. Results from the first two tiers will help investigators select targeted sites for tier 3, which consists of collecting water samples at targeted sites and having laboratories analyze the samples for chemical tracers of wastewater. Although the laboratory analyses can be expensive, results from these tier 3 analyses generally offer greater potential for diagnosing wastewater presence (or absence) than results from tier 1 and 2 efforts alone.

\section{Trolling-Instrument Surveys of Surface-Water Properties}

Streams, storm drains, and other surface-drainage features that carry runoff to coastal waters typically are straightforward to identify, but locations of groundwater discharge to coastal waters are less apparent. Such locations of groundwater discharge to coastal waters in Hawai' $i$ sometimes can be identified as anomalous points or areas of fresher and commonly colder water relative to ambient ocean water. In streams and estuaries, locations that have anomalous water characteristics may be indicative of groundwater discharge. Each of these anomalies identifies sites to consider for subsequent watersampling efforts.

\section{Purpose}

The purpose of trolling-instrument surveys is to provide understanding of various physical and chemical properties (for example, temperature, $\mathrm{SC}$, dissolved oxygen, $\mathrm{pH}$ ) of surface water in the study area. Maps showing the spatial distributions of physical properties will highlight water anomalies such as groundwater-discharge locations where investigators likely will want to collect water samples. The maps are prepared from a dataset of physical properties that can be obtained by trolling an instrument that both measures and records water properties near the water surface at set time intervals. 
The water-property maps alone cannot be used to infer wastewater presence or nutrient sources, but they can provide clear, visible patterns that can help investigators select sites for subsequent water-sampling efforts. The surveys also provide investigators with the opportunity to identify other potentially relevant features such as obscured stormdrain outlets, animal-waste deposits, sediment deposits from recent runoff events, and exposed soil from erosion or disturbances from humans or animals. The simple trolling surveys described here also could be complemented with relatively complex aerial surveys that measure surface-water temperature (see, for example, Johnson and others, 2008; Kelly and others, 2013; Lee and others, 2016).

\section{Presurvey Tasks}

First, a water-quality sonde is selected that is capable of measuring and recording desired water properties. Temperature and $\mathrm{SC}$ are relevant properties to measure in coastal waters. Dissolved-oxygen measurements also might be useful because they can indicate the state of reductionoxidation conditions, which can help investigators interpret selected results (for example, nitrogen and oxygen isotopes in nitrate) for water samples collected for later efforts of the source-tracking approach. Other properties such as $\mathrm{pH}$, chlorophyll $a$, and turbidity also may be useful, depending on the study area. A sonde that can measure nutrients in the water of the survey area also can be considered. Next, a laboratory check of each water-quality sensor is performed to ensure that its measurements are accurate (see, for example, Gibs and others, 2012; USGS, 2019).

Two global positioning system (GPS) receivers (one primary and one backup) are used to record latitude and

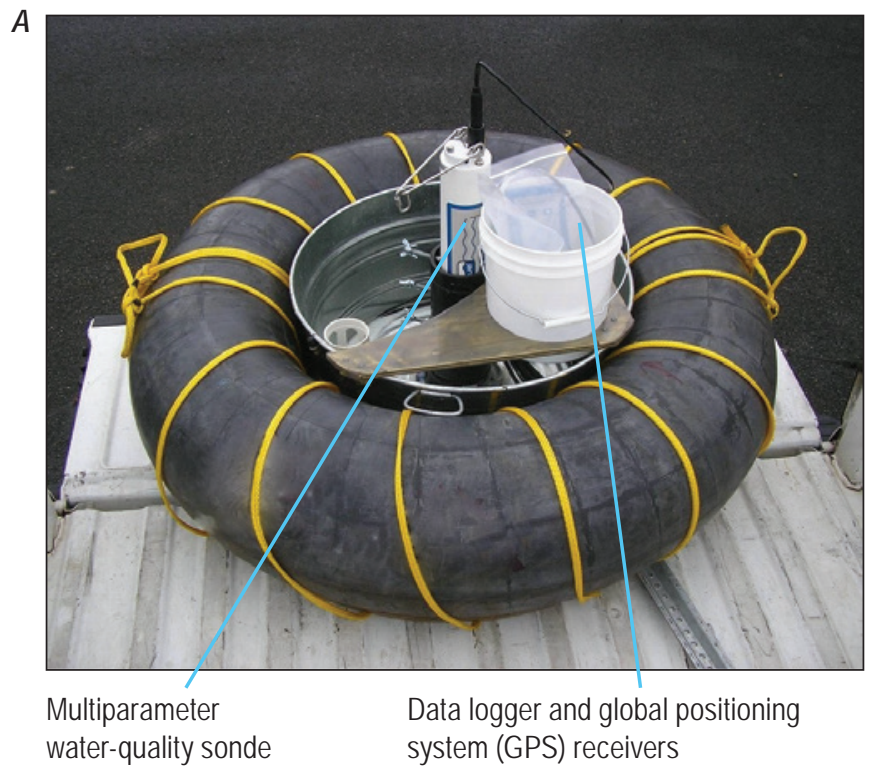

longitude values measured at the same time intervals as the water-quality sonde measurements. The accuracy of the GPS receivers ideally is a few meters or better. The measurements of the sonde and GPS receivers can be exported and then merged and formatted for input to a GIS.

The extent of the survey area is chosen with the intent of mapping water properties within a few hours, and a mapping method such as wading or kayaking platforms (fig. 3) is selected. During their source-tracking studies on Maui, Hunt and Rosa (2009) used both wading and kayaking methods to conduct trolling surveys in coastal waters near Kîhei and Lahaina. Although Hunt and Rosa (2009) noted that kayak surveys were quicker and allowed multiple transects to be completed farther offshore, they considered wading surveys to be better for sensing visual and temperature contrasts in the water. They also noted that the prominent submarine springs at Kîhei might have garnered less attention had they omitted the wading survey.

The survey paths can be planned to ensure that measurements will be collected at a desired density, given the extent of the survey area. The general direction of water flow and currents are considerations when planning the survey paths because physical properties generally are measured in water that has not been disturbed by field personnel. For example, if the survey area includes a flowing stream, then field personnel would record measurements only as they wade upstream into water they have not yet disturbed.

A time period to complete the survey is chosen after the tidal, surf, and weather conditions that are likely to affect water properties are considered. For example, groundwater discharge to coastal ocean waters likely is most apparent when the tide is ebbing to low tide (Urish and McKenna, 2004; Peterson and others, 2009), during calm-surf conditions, and in the early

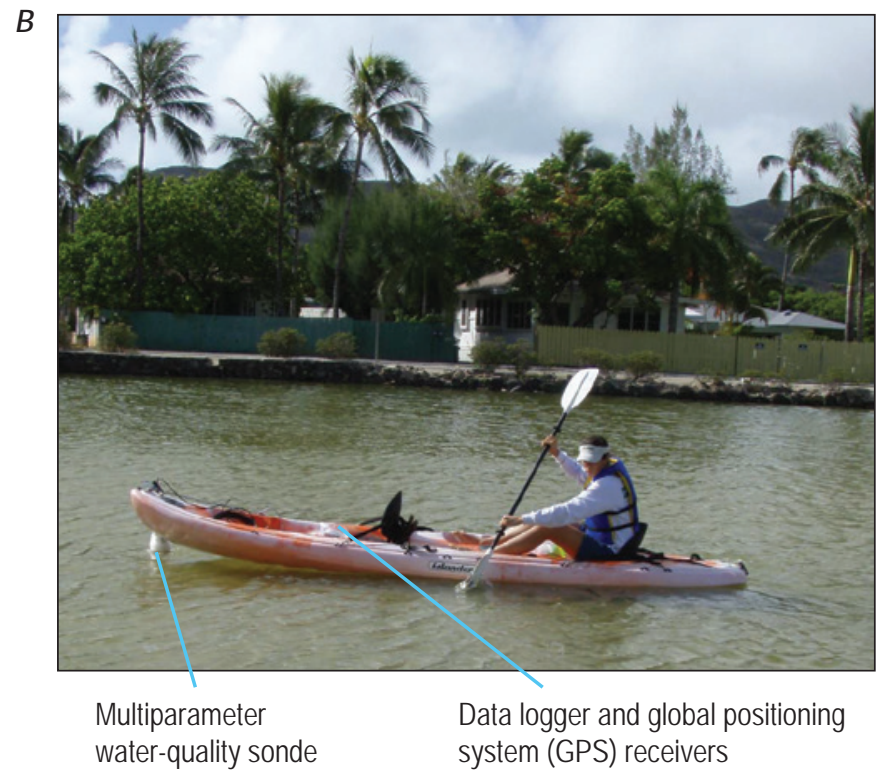

Figure 3. Photographs showing $(A)$ wading platform and $(B)$ kayaking platform used for trolling-instrument surveys in estuaries and coastal ocean waters, O‘ahu, Hawai'i, 2007-08. Photographs by Charles (Chip) Hunt, Jr., 2007 and 2008. 
morning before surface waters are warmed by the sun. Investigators ideally would aim to complete the survey in a few hours to minimize the effects of changing environmental conditions.

\section{Trolling Survey}

The sensors of the water-quality sonde should be calibrated before mounting the sonde to the kayak or wading platform. If the survey is to be done with a kayak, the waterquality sonde is then mounted to the bow of the kayak so that the sonde measures water properties from just below to within a foot $(\sim 0.3 \mathrm{~m})$ of the surface, as relatively fresh groundwater discharging into coastal ocean water will buoyantly rise to near the water surface. If the survey is to be done by wading, a floating platform is prepared and the sonde is attached to it.

Next, the clocks of the sonde and the GPS receivers are synchronized, and the sonde and GPS receivers are programmed to record data at the same time interval, such as every 20 seconds. Once the sonde and GPS receivers start recording data, the survey can begin. The sonde is trolled at a steady pace, and noticeable changes in wind, surf, sunlight, and other conditions that may affect the survey results are recorded by field personnel.

\section{Evaluating Trolling-Instrument Survey Data}

The survey data can be compiled into maps for evaluation. First, the data files from the water-quality sonde and GPS receivers are merged, using their common time stamps. Next, $\mathrm{SC}$ measurements and the following simplified equation (eq. 1) are used to compute the freshwater percentage of each data point:

Freshwater percentage $=\left[1-\left(\mathrm{SC}_{\mathrm{m}} / \mathrm{SC}_{\mathrm{ow}}\right)\right] \times 100$ percent $(1)$

where

$$
\begin{array}{cc}
\mathrm{SC}_{\mathrm{m}}= & \text { measured specific conductance; and } \\
\mathrm{SC}_{\mathrm{ow}}= & \begin{array}{c}
\text { specific conductance of ocean } \\
\text { water. }
\end{array}
\end{array}
$$

For equation 1, the $\mathrm{SC}$ of ocean water $\left(\mathrm{SC}_{\mathrm{ow}}\right)$ can be set at 53,087 microsiemens per centimeter (Wagner and others, 2006), unless a local value is available; alternatively, if salinity is measured instead of SC, then 35 practical salinity units can represent the salinity of ocean water in equation 1 . Lastly, the survey results and computed freshwater percentage values are imported into a GIS, and a map of each water-quality property is created.

The usefulness of each property can vary by study area. Freshwater percentage is the most straightforward property to interpret: values near 100 percent (low SC) are indicative of freshwater, and values near 0 (high SC) are indicative of ambient ocean water. Freshwater signatures, however, may dissipate quickly during rough surf conditions.

Although the remaining properties may vary with the daylight cycle and, thus, their interpretation is less straightforward, they still may be useful. Water temperature can be used to identify groundwater seeps at beaches if the temperatures of ambient groundwater and ocean water are substantially different. For example, relatively cold plumes of groundwater that have discharged to relatively warm coastal waters in Hawai' $i$ have been identified with aerial surveys of surface-water temperature (Johnson and others, 2008; Kelly and others, 2013, 2019). Water-temperature measurements from a trolling survey, however, likely will reflect daytime heating if the survey is not completed within the early-morning hours.

Evaluations of dissolved-oxygen measurements require an understanding of oxygen sources and sinks, as well as of processes that can affect dissolved-oxygen concentrations. Dissolved oxygen in water comes from the atmosphere and is produced by aquatic plants and algae during photosynthesis. Dissolved oxygen is consumed by aquatic organisms that respire and by bacteria that decompose organic matter. Oxygen also is consumed in the nitrification process, during which bacteria first convert ammonia or ammonium to nitrite and then convert nitrite to nitrate (Knowles, 1982).

Both dissolved-oxygen concentrations and $\mathrm{pH}$ in coastal ocean waters have been shown to vary with the daylight cycle (Halley and Yates, 2008). Both increase during the daytime when photosynthesis consumes carbon dioxide and produces oxygen. Both decrease during the night when respiration by organisms consumes oxygen and produces carbon dioxide. In 22 streams on $\mathrm{O}^{\prime} \mathrm{ahu}$, dissolved-oxygen concentrations measured near noon were observed to be higher than those measured in the morning, before sunrise (Viau and others, 2011).

Rapidly moving water in streams typically is well aerated and contains considerable dissolved oxygen from the atmosphere. Stagnant surface-water bodies may contain low dissolved-oxygen concentrations at depth, owing to consumption of oxygen by respiring organisms and by bacteria decomposing organic carbon near the bottom of the water column. Groundwater that contains high amounts of organic carbon, such as that affected by wastewater, also may have low dissolved-oxygen concentrations, owing to oxygen consumption during aerobic degradation of organic carbon. Hunt and Rosa (2009) observed relatively low dissolvedoxygen concentrations (1) in groundwater within a wastewater plume from an injection well at Kīhei, Maui, and (2) near submarine springs in coastal waters near Kīhei and Lahaina, Maui. Locations determined to have relatively low dissolvedoxygen concentrations might be appropriate places to collect reconnaissance samples.

\section{Reconnaissance Sampling for Optical Brighteners and Specific Conductance}

The next step of the source-tracking approach is to collect water samples at reconnaissance-sampling sites and then analyze the samples for optical brighteners and SC. Also called fluorescent whitening agents or fabric brighteners, optical brighteners are added to many laundry detergents, and 
they typically are found in household wastewater. Thus, the presence of optical brighteners in water samples from a site can be used to infer the presence of household wastewater in the environment (Cao and others, 2009).

Investigators can determine the presence or absence of optical brighteners in water samples on the basis of fluorescence measurements from a handheld fluorometer. SC measurements also can be done quickly and can reveal freshwater anomalies in coastal environments. Results of the optical-brightener testing and SC measurements can help investigators select targeted sites where additional water samples for chemical analyses can be collected.

\section{Selecting and Inspecting Reconnaissance-Sampling Sites}

Background information and maps of water properties can help investigators select reconnaissance-sampling sites. If investigators are attempting to identify the source(s) of elevated bacteria counts at a beach-monitoring site, they typically would consider including reconnaissance-sampling sites that are distributed in the watershed area inland of that beach-monitoring site. The reconnaissance-sampling sites also could include nearby locations of groundwater discharge to the ocean. Investigators could strategically distribute the sampling sites according to certain land uses (current or former) in the watershed area. For example, one set of sites could be within mostly forested areas; a second set could be within agricultural areas; a third set could be within developed areas; and a fourth set could be downstream from, or seaward of, each type of selected land use. In watershed areas that contain streams, several reconnaissance-sampling sites could be distributed along each stream's flow path, beginning at a site inland from most potential sources of nutrients and ending at a site at the coastline. Investigators also can distribute their sampling sites between areas that have OSDSs and those that do not. Investigators might also consider a paired-watershed approach, in which samples are collected from two watersheds. For example, the two watersheds could be adjacent to each other and have similar land-cover types, but buildings in the first watershed might be connected to cesspools and septic systems predominantly, whereas buildings in the second watershed might be connected to a municipal sewer system. In general, if a site of interest can be safely accessed and sampled without great difficulty, then the site should be included on a list of reconnaissance-sampling sites. Also, a sample of each of the study area's source waters (for example, ambient freshwater, ocean water, and tap water) should be collected; this is a critical step in the reconnaissance-sampling approach.

Field personnel ideally would inspect each selected site prior to the sample-collection day. Site inspections allow field personnel to determine how to safely collect a sample and then decide on the sampling equipment needed. When inspecting each stream, ditch, or canal site, field personnel can decide whether or not samples can be safely collected by wading or whether sampling equipment will need to be lowered from a structure such as a bridge, cableway, or boat.

Field personnel must exercise appropriate caution when deciding whether or not it is safe to wade at each flowingwater site. At a minimum, a flowing channel is considered unsafe to wade in if its depth (in feet), multiplied by its velocity (in feet per second), equals 10 or greater $^{1}$ (Wilde and others, 2014). During the site inspections, field personnel also can record preliminary SC measurements, which will help them select appropriate SC-calibration standards for the site.

\section{Selecting Reconnaissance-Sampling Periods and Conditions}

Investigators should plan when they want to collect samples and then decide which environmental conditions are appropriate for sampling. Investigators can use records of rainfall, streamflow, and bacteria counts for the study area to decide whether sampling should be done during a particular season (wet, dry, or both) or during particular weather conditions (storm, fair weather, or both). For example, if elevated bacteria counts typically occur immediately after heavy rainfall during the wet and dry seasons, investigators might decide to collect one round of reconnaissance samples during or immediately after a storm. Investigators may also want to collect one round of reconnaissance samples during fair-weather conditions and then compare results for fairweather conditions with those for heavy-rainfall conditions.

Investigators commonly will consider how tide, surf, and sunlight conditions may affect the waters being sampled. In general, low-tide and calm-surf conditions are best for sampling sites where groundwater may be discharging to coastal ocean waters. Also, because optical brighteners degrade when exposed to ultraviolet (UV) light, reconnaissance samples at surface-water sites generally are collected during earlymorning hours, preferably before sunrise; at unsheltered groundwater sites, therefore, field personnel might consider using a canopy and opaque, physical barriers to ensure that groundwater samples are not exposed to direct sunlight.

\section{Selecting Reconnaissance-Sample-Collection Methods and Equipment}

Various sampling methods and equipment are available for use at different types of surface-water and groundwater sites (see, for example, Wilde and others, 2014). At coastalocean and estuary sites, grab samples can be collected using either dip- or discrete-sampling methods: the dip-sampling method involves dipping an open-mouth bottle into the water; the discrete-sampling method involves lowering a closed bottle to a specific depth and then opening, filling, and closing the bottle at that depth. The dip-sampling method

\footnotetext{
${ }^{1}$ If depth is measured in meters and velocity is measured in meters per second, then a flowing channel is considered unsafe to wade in if its depth multiplied by its velocity equals 0.9 or greater.
} 
might be useful at coastal-ocean and estuary sites where investigators are targeting groundwater discharge and where $\mathrm{SC}$ measurements at these sites indicate that fresher water is near the ocean surface. The discrete-sampling method might be useful at coastal-ocean and estuary sites where freshwater seems to be seeping up from the ocean floor. Because organic contaminants may be concentrated in a surface microlayer (that is, in the uppermost about 0.04 in (1 millimeter [mm]) of the water column; Hardy, 1982; Hardy and others, 1990; Cincinelli and others, 2001), the presence of this microlayer may affect the selection of an appropriate sampling method. Sampling at a specific depth is straightforward when wading because field personnel can lower, open, and then close the bottle at the specific depth. If wading is not feasible, however, a pump-sampling device could be used to collect a sample at a specific depth (Wilde and others, 2014).

At sites of flowing surface water such as streams, canals, or ditches, either the dip- or the discrete-sampling method can be used to collect samples. If field personnel can collect samples while wading, they can dip and fill the sample by hand while standing downstream from the bottle as it fills with water. If field personnel are collecting a sample from a bridge or other structure, the bottle can be placed in a weighted bottle holder (for example, the stainless steel US WBH-96 model [Wilde and others, 2014] or other simple, handmade types [see fig. 4]), which is then lowered into the water by rope or line.

When sampling a stream, ditch, or canal, one option would be to fill a single sample bottle near the center of the flowing channel. Another option would be to divide the width of the flowing channel into several sections of equal width and then collect a grab sample at the center of each section; the sampled water from each section could be retained for analysis of optical brighteners and measurement of SC. The center-only sampling option requires less field time than the multisection sampling option, but the multisection sampling option may capture optical brighteners that are missed by the center-only sampling option. With either option, field personnel might choose to fill a bottle either (1) by lowering and then raising the open bottle vertically through most of the water column or (2) at specific depth, such as near the water's surface.

The collection of storm-condition samples at stream sites can be difficult in Hawai' $i$, owing to uncertainties in weather forecasts and flashy streamflow conditions in many watersheds. The use of unattended samplers, therefore, can aid investigators with the collection of storm-condition samples. Two types of unattended samplers are (1) complex, powered autosamplers (figs. 5A, B) that the USGS currently (2020) operates at several sites on $\mathrm{O}^{\prime}$ ahu and (2) relatively simple and inexpensive stage-level samplers that can be secured to a stationary feature at a site (fig. 5C). A powered autosampler is programmed to pump water from the stream during storm conditions; the pumped water is stored in bottles held in a refrigerated container near the sampling site. A stage-level sampler consists of a container that is set at a fixed height and holds a sample bottle that fills when a stream's stage rises above the level of the container.
The four sampling methods described above are considered as nonisokinetic sampling methods because they use sampling devices (bottles and tubes) into which water enters at a velocity that generally differs from that of the water flowing in the stream. The use of nonisokinetic sampling methods is considered acceptable for reconnaissance sampling because the main objective of these efforts is simply to determine the presence or absence of optical brighteners at a site (not the loads of optical brighteners carried by flowing surface water at that site).

To sample groundwater (beach pore water) at beaches, beach pore water can be pumped into sample bottles from tubing lowered into a cylinder driven vertically into beach sand by a vibratory hammer drill (fig. 6). The CWB and USGS used this method to collect beach pore-water samples at Kualoa Regional Park and Kahana Beach Park on O'ahu in 2007 (fig. 6A).

Groundwater samples also can be collected at watersupply wells and at monitoring wells; guidelines for purging wells and collecting samples from each type of well can be found in USGS (2006). Advantages of sampling an in-service supply well include (1) the well already has a pump installed, (2) groundwater can be collected at a wellhead faucet or tap, and (3) time spent purging the well can be minimal if the well has been running continuously. Field personnel, however, need to ensure that the groundwater being sampled has not been stored in a holding tank or treated with chemicals.

Groundwater-monitoring wells ideally are sampled using a portable pump and tubing (fig. 6), but this is not always possible. Tillman and others (2014a) used bailers (fig. 6) to collect groundwater samples at deep monitoring wells near

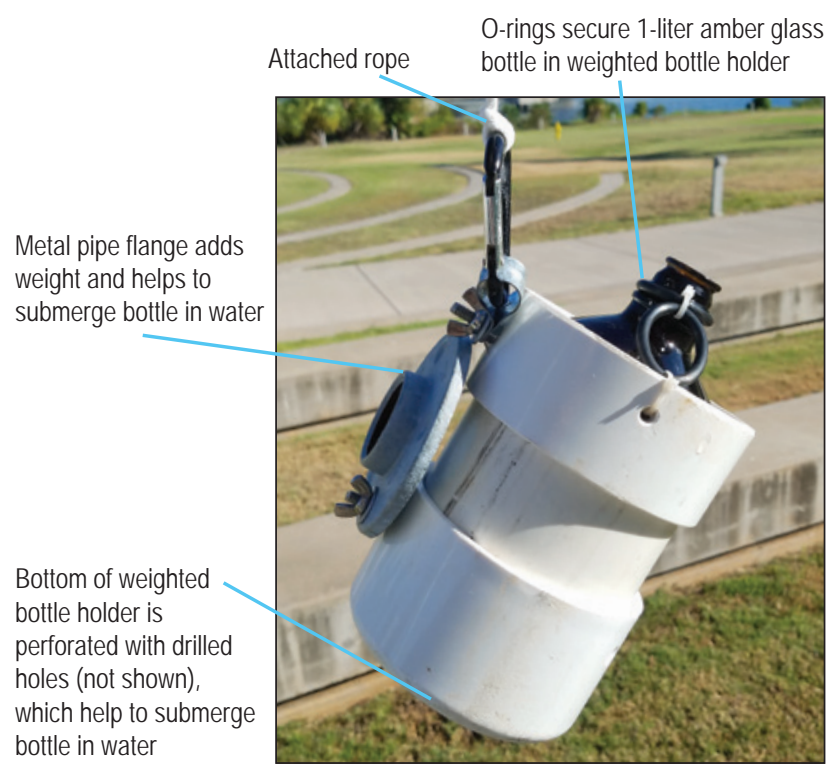

Figure 4. Photograph of handmade, weighted bottle holder that can be used to collect nonisokinetic stream samples from bridges. Photograph by Adam Johnson, May 31, 2019. 
A When stream stage rises above threshold level, equipment in gage house pumps water from stream, through tubing within pipe secured to stream bank, and into gage house

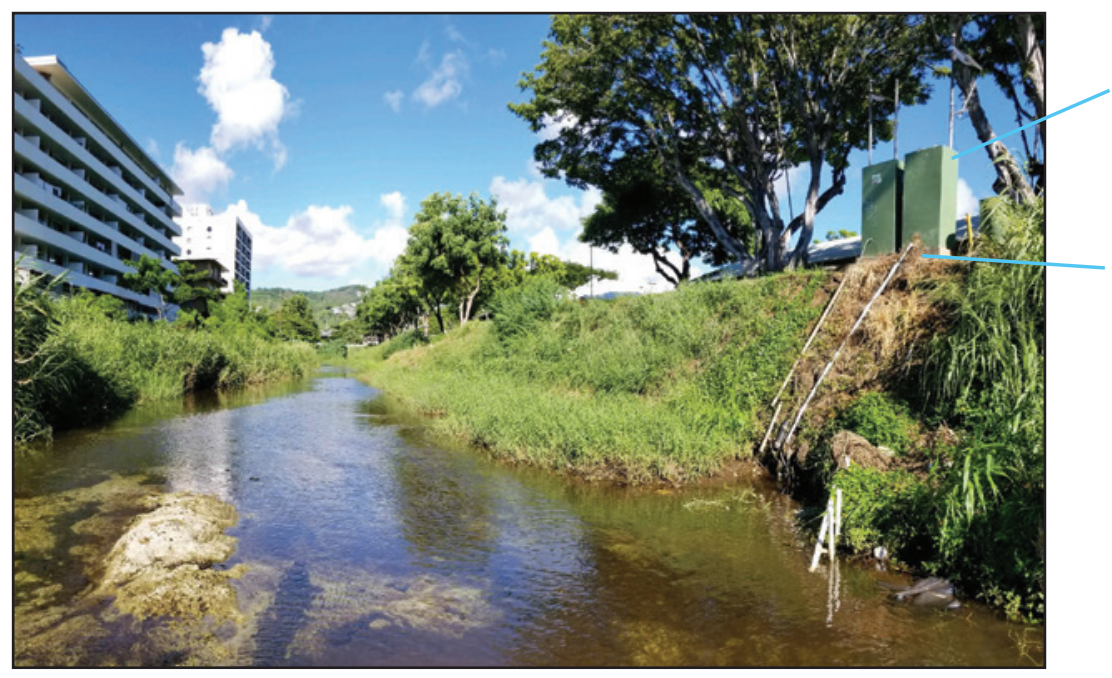

Gage houses with battery-powered autosampling equipment and stage-monitoring equipment

Some pipes contain stage-monitoring equipment and tubing used to collect suspended-sediment samples

B. Gage-house equipment used to monitor stream stage and transmit measurements to database and publicly accessible website

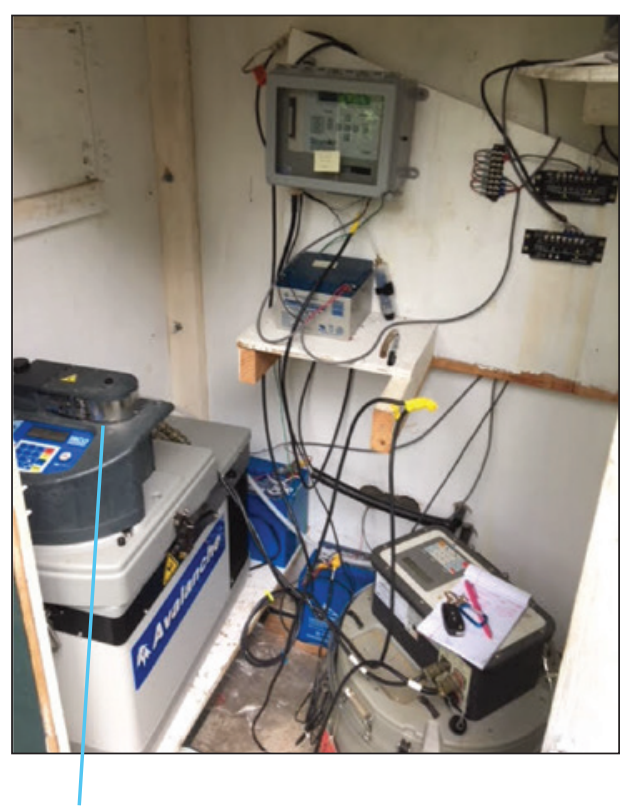

Battery-powered autosampling equipment in gage house pumps water from stream, through tubing along stream bank, and into sample bottles that are kept chilled
C. Stage-level sampler

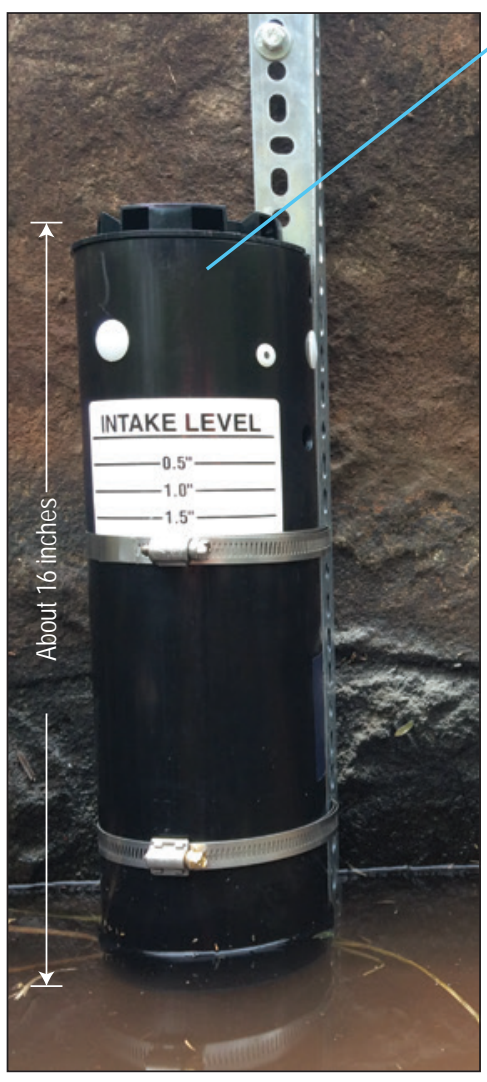

Stationary container holds sample-bottle intake above stream stage during fair-weather conditions

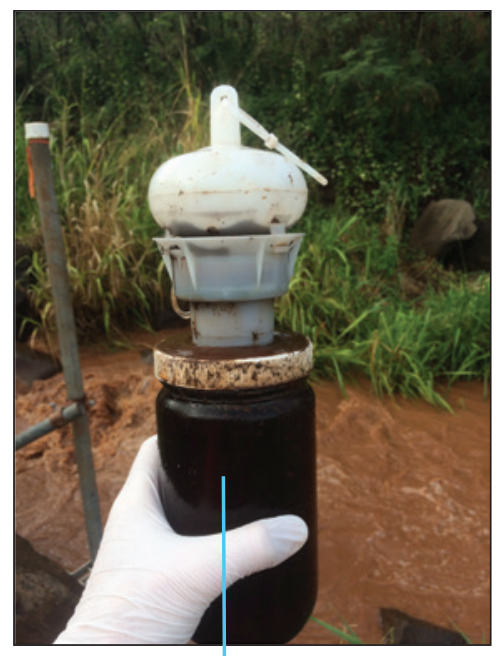

Sample bottle retrieved from container after storm conditions, during which stream stage rose and submerged container, and then stream water flowed into the sample bottle

Figure 5. Photographs showing unattended equipment used to collect samples at stream sites during storm conditions. A, Gage houses at U.S. Geological Survey site number 16247100, Mānoa Palolo Drainage Canal, O'ahu, Hawai'i, where stream stage is monitored continuously and where water samples are collected by autosampling equipment during storm conditions. Photograph by Rylen Nakama, November 1, 2019. B, Inside of gage house containing equipment used to monitor stream stage and autosampling equipment used to collect and store water samples. Photograph by Daniel Sinclair, November 12, 2019. C, Stage-level sampler used to collect water sample in 2016 during storm conditions from stream on O'ahu, Hawai'i. Photographs by Joseph Kennedy (left), January 9, 2017, and Adam Johnson (right), February 11, 2017. 
A Beach pore water pumped through sample tubing

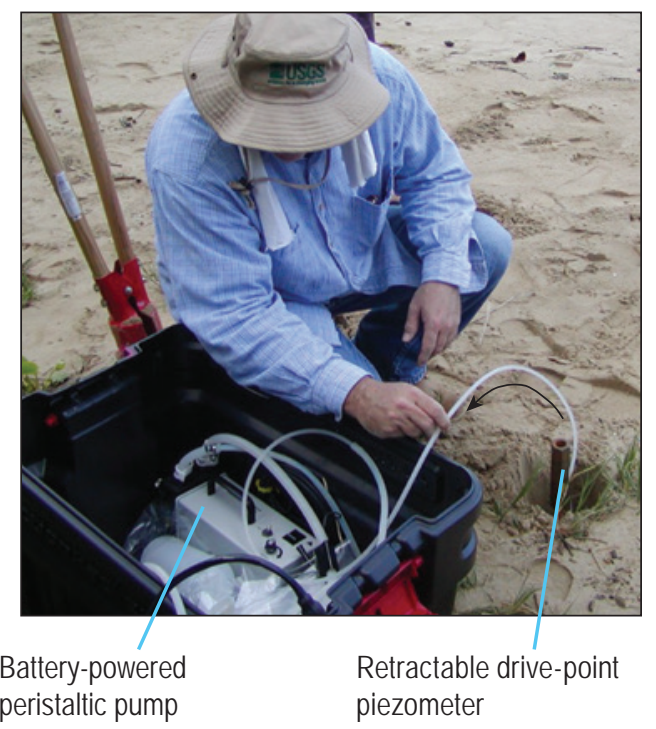

C. Hand-operated reel with braided stainless-steel wire used to lower bailer into monitoring well and retrieve groundwater sample

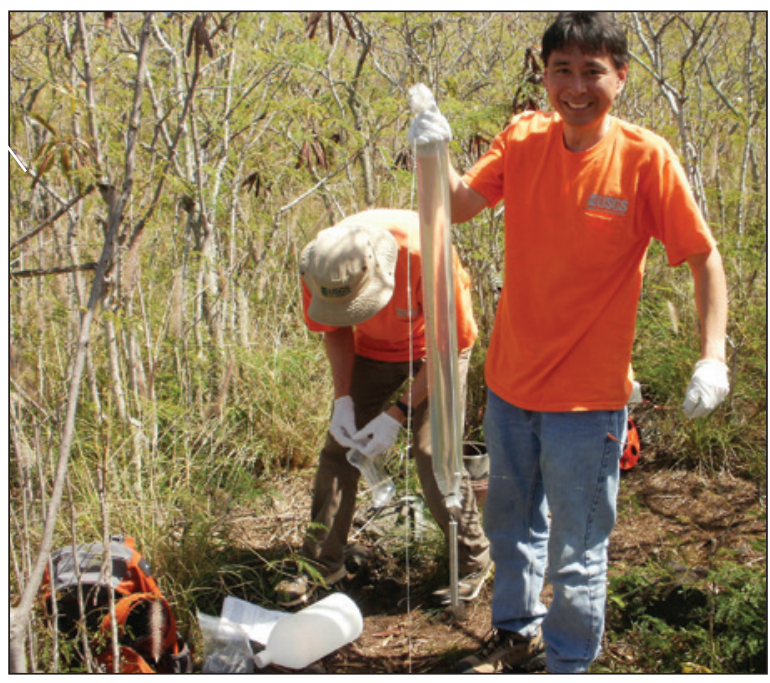

B. Groundwater pumped from well through tubing and into chamber

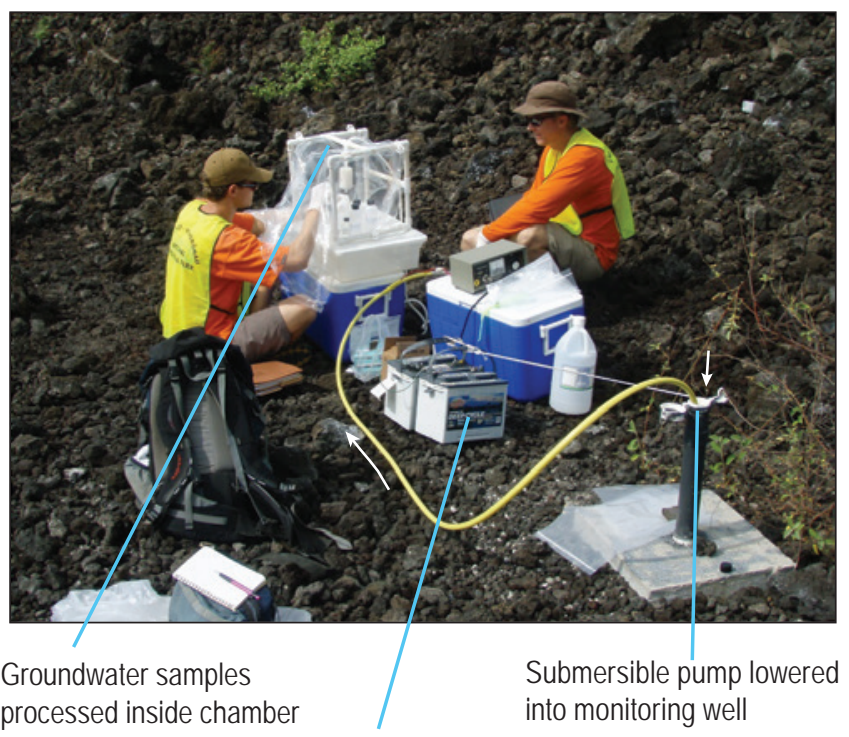

Battery-powered
Submersible pump lowered into monitoring well pump control

processed inside chamber

Figure 6. Photographs showing sampling techniques and equipment. A, Equipment used to collect beach pore-water samples at Kahana Beach Park, O'ahu, Hawai'i. Photograph by John Engott, 2007. B, Submersible pump and tubing used to collect groundwater samples from monitoring well at Kaloko-Honokōhau, Hawai'i Island, Hawai'i. Photograph by Delwyn Oki, 2012. C, Bailer used to collect groundwater sample from monitoring well near Kaloko-Honokōhau, Hawai'i Island, Hawai'i. Photograph by Fred Tillman, 2013. 
Kaloko-Honokōhau, Hawai'i Island, because a portable pump was not capable of lifting water to the land surface at the sites. Additional information on various types of groundwater-sampling equipment can be found in Wilde and others (2014).

\section{Preparing for Sample Collection for Optical-Brightener Testing and Specific Conductance Measurement}

To prepare for sample collection, the proper materials required for the collection of water samples must be gathered; figure 7 shows several example lists of sample-collection materials for various hypothetical sites. For example, water samples that will be analyzed for optical brighteners will need to be stored in opaque bottles (such as brown, 250-milliliter [mL] polyethylene bottles that have black caps) to minimize exposure to sunlight after collection. The volume of each sample bottle needs to be large enough to contain water for triplicate fluorescence measurements and one SC measurement.

All sampling equipment must be cleaned prior to use. Bottles that will store sampled water to be analyzed for optical brighteners usually are purchased new and then triple-rinsed with deionized water prior to use in the field. Sample tubing is cleaned by soaking and washing in a dilute, nonphosphatesoap solution and then rinsing with deionized water (see, for example, Wilde, 2004). Disposable, powderless nitrile gloves must be worn by personnel who clean and handle sampling equipment. Sample bottles and weighted bottle holders should be stored and transported in clean plastic bags.

Any sampling equipment that is reused at more than one sampling site must be cleaned after use at each site to minimize cross contamination. Because cleaning the equipment in the field can be time consuming, personnel ought to consider preparing a clean set of sampling equipment for each site in advance.

Next, equipment required for testing water samples for optical brighteners and for measuring SC is obtained (fig. 8). A detergent-calibration solution should consist of 50 microliters $(\mu \mathrm{L})$ of laundry detergent mixed with 1 liter (L) of deionized water. Cao and others (2009) used Tide laundry detergent (Tide Original Scent $2 \mathrm{x}$ ) to prepare their detergent-calibration solution; the detergent-calibration solution should be stored in a refrigerator. Solutions for SC-calibration should bracket the anticipated range of SC values at the sampling sites.

Next, solution and equipment blanks are collected and measured for fluorescence. Solution blanks are blank water that has not contacted any sampling equipment. Equipment blanks are quality-control samples that allow investigators to determine whether the sampling equipment and (or) the equipment-cleaning procedures may contaminate or otherwise affect the fluorescence readings of the sampled environmental water (Horowitz and others, 2004). The blank water might be deionized water that will be used to calibrate the fluorometer to zero fluorescence units (see section below entitled, "Determining the Presence or Absence of Optical Brighteners"). One equipment blank needs to be collected for each unique set of sample-collection equipment. For example, if grab samples will be collected at surface-water sites by dipping sample bottles, then the equipment blank would consist of blank water that has been poured into a sample bottle. If tubing and a submersible pump are going to be used to collect groundwater samples, then the equipment blank would consist of blank water that has been pumped through the pump and tubing and then into a sample bottle. The fluorescence of the solution blank and each equipment blank is then measured using a handheld fluorometer. If the fluorescence reading of an equipment blank is substantially different from that of the solution blank, then different sampling equipment and (or) equipment-cleaning procedures are needed.

\section{Collecting Water Samples for Optical-Brightener Testing and Specific Conductance Measurement}

Samples are collected at the designated sampling sites, using one of the methods described above, and, ideally, SC is measured at each site. Field personnel must wear powderless nitrile gloves when handling sampling equipment; however, water that enters the sample bottle must not contact gloved hands. At each sampling site, the sample bottle (and cap) is rinsed three times with the site's water, then the bottle is filled with water and the bottle's cap is secured. The sampling date and time are recorded in field notes, and the sample bottles are labeled with the date, time, and site name and then immediately placed in ice-filled coolers until analysis.

\section{Determining the Presence or Absence of Optical Brighteners}

The testing procedures of Cao and others (2009) are used in this report for determining the presence or absence of optical brighteners in water samples. The procedures involve fluorescence measurements that are combined with controlled exposure of samples to UV light. Controlled UV-light exposure enables investigators to distinguish between optical brighteners and types of organic matter that absorb and emit light at wavelengths that are similar to that of optical brighteners. The procedures take advantage of the fact that optical brighteners degrade more rapidly than organic matter does when exposed to UV light (Cao and others, 2009).

The testing procedures are conducted inside a building that has minimal exposure to sunlight. The UV lamp is placed in an enclosed space where cuvettes filled with sampled water can be exposed to the UV lamp's output. The fluorometer's settings are adjusted to measure fluorescence between 415 and 445 nanometers $(\mathrm{nm})$ in response to excitation between 300 and $400 \mathrm{~nm}$. For example, Hunt (2014) successfully tested Hawai' $i$ Island water samples for optical brighteners using a handheld fluorometer that measured fluorescence at $445 \mathrm{~nm}$ in response to excitation at $375 \mathrm{~nm}$. The meter is calibrated to 0 fluorescence units using deionized water and to 50 fluorescence units using the prepared detergent calibration solution. 
SAMPLING EQUIPMENT

(for all sites)

- Nitrile gloves

- 250-milliliter brown polyethylene bottle to store water to be tested for optical brighteners and specific conductance

- Bottle label with site name

- Computer and software to record sample date and time

- Ice-filled cooler

\section{SAMPLING EQUIPMENT} (for surface-water sites)

- Weighted bottle holder and rope if site cannot be waded and sample will be collected from a bridge or other structure

- Additional 250-milliliter brown polyethylene bottles if multiple samples will be collected at site

\section{SAMPLING EQUIPMENT}

(for beach pore-water sites)

- Shovel

- Hammer drill and battery

- Retractable drive-point piezometer

- Drill attachment to push drive-point piezometer into beach sand

- Peristaltic pump and battery

- Length of tubing compliant with peristaltic pump

\section{SAMPLING EOUIPMENT}

(for water-supply wells that have existing pump in operation)

- Timer

- Sonde to measure physical properties of pumped water during well purge

- Container to hold water pumped from well during well purge

\section{SAMPLING EOUIPMENT}

(for monitoring wells that can be sampled with submersible pump)

- Steel tape and chalk to determine water level in well

- Pump-control unit and battery

- Submersible pump and tubing of adequate length

- Rope or clamp to set pump at desired depth in monitoring well

- Timer

- Container to hold water pumped from well during well purge

- Sonde to measure physical properties of pumped water during well purge

Figure 7. Examples of lists of sampling equipment used to collect reconnaissance water samples at different types of sites. 


\section{EOUIPMENT FOR OPTICAL-BRIGHTENER TESTING}

\section{(to be done indoors)}

- Fluorometer (for example, Aquafluor handheld model [Turner Designs, Sunnyvale, Calif.])

- Multiple cuvettes for use in fluorometer

- Prepared detergent calibration solution (50 microliters of liquid laundry detergent in 1 liter of deionized water)

- Ultraviolet lamp

- Opaque container that encloses ultraviolet lamp and multiple fluorometer cuvettes

- Timer

- Nitrile gloves

- Nonscratching wipes to clean outside of cuvettes

- Prepared cuvette-cleaning solution (1 milliliter of nonphosphate laboratory soap diluted in 1 liter of tap water)

- 1-liter squirt bottle filled with cuvette-cleaning solution

- 1-liter squirt bottle filled with deionized water to rinse cuvettes

- Small tub to dispose of used calibration solution, used sample water, and used cuvette-cleaning solution

- Computer and spreadsheet software to record fluorescence measurents

\section{EOUIPMENT FOR SPECIFIC CONDUCTANCE MEASUREMENTS}

(to be done indoors or at sample site)

- Specific conductance meter (for example, YSI EC300A model [YSI Incorporated, Yellow Springs, Ohio])

- Calibration cup

- 1 liter each of selected specific conductance calibration solutions (for example, calibration solutions of 50, 100, and 500 microsiemens per centimeter for freshwater sites)

- 1-liter squirt bottle filled with deionized water

- Small tub to dispose of used sample water and used calibration solutions

- Computer and software to record specific conductance measurements

Figure 8. Examples of lists of equipment used to test water samples for optical brighteners and specific conductance. 
For each water sample, the water is gently mixed and then poured directly into the three clean cuvettes that are required by the fluorometer; the sample water is not filtered. The fluorescence of the water in each cuvette is measured, following the instructions of the fluorometer's manual. The average of the triplicate fluorescence measurements is recorded as the sample's initial fluorescence before UV-light exposure. For each sample, the triplicate fluorescence measurements are repeated after 5 minutes (min) of UV-light exposure and then again after an additional 5 min of UV-light exposure (that is, after 10 total min of UV-light exposure). If any cuvette is used for more than one sample, the cuvette is cleaned between measurements of different samples.

After all measurements have been completed, equation 2 is used to calculate the percentage reduction after both 5 and 10 min of UV-light exposure.

$$
P R_{x}=\frac{\left(F_{0}-F_{x}\right)}{F_{0}} \times 100 \text { percent }
$$

where

$$
\begin{array}{r}
P R_{X}=\begin{array}{r}
\text { the percentage reduction in fluorescence at } \\
x(5 \text { or } 10) \text { min of UV-light exposure; }
\end{array} \\
F_{0}=\begin{array}{c}
\text { the average initial fluorescence reading } \\
\text { before UV-light exposure; and }
\end{array} \\
F_{X}=\begin{array}{r}
\text { the average fluorescence reading at } x \\
(5 \text { or } 10) \text { min UV-light exposure. }
\end{array}
\end{array}
$$

Next, the following empirically based decision model from Cao and others (2009) is applied to each sample to determine whether the sample contains optical brighteners:

- Test 1.-If a sample's initial fluorescence value is less than 5 (which is equivalent to a detergent concentration of $5 \mu \mathrm{L} / \mathrm{L}$ ), then the sample is considered negative for optical brighteners. Otherwise, proceed to test 2 .

- Test 2.-If the reduction in fluorescence after $5 \mathrm{~min}$ of UV-light exposure is less than 8 percent, then the sample is considered negative for optical brighteners. If the reduction is greater than or equal to 30 percent, then the sample is considered positive for optical brighteners. Otherwise, proceed to test 3.

- Test 3.- -If the ratio of (1) the percentage reduction after 10 min of UV-light exposure to (2) the percentage reduction after $5 \mathrm{~min}$ of $\mathrm{UV}$-light exposure is greater than or equal to 1.5 , then the sample is considered negative for optical brighteners. Otherwise, the sample is considered positive for optical brighteners.

Note that the testing procedures described in this report may not detect optical brighteners at sites where the concentration of wastewater is low (Cao and others, 2009).

Table 2 shows a worksheet template that can be used to record fluorescence measurements and percent-reduction values.

\section{Measuring Specific Conductance}

After completing the fluorescence measurements, investigators can measure the SC of the remaining water in each sample bottle. Alternatively, $\mathrm{SC}$ can be measured in place at each sampling site at the time of sample collection and recorded in field notes. In either case, SC is measured with a meter device that has been calibrated using appropriate procedures, such as those described in USGS (2019). SC measurements can be converted to freshwater-percentage values using equation 1 in this report.

\section{Evaluating Results}

After testing, a table of values is prepared and a map of the sampling sites is compiled that has labels indicating freshwater-percentage values and the presence or absence of optical brighteners. Sites that contain optical brighteners are good sites to target for collection of additional water samples that can be analyzed for chemical tracers of wastewater. However, the absence of optical-brightener detections at a site may not definitively indicate the absence of wastewater because of inherent limitations of using optical brighteners for wastewater tracking. For example, optical brighteners may not be detected at sites where the wastewater concentration is low (Cao and others, 2009), as noted above. In addition, optical brighteners may be absent from the wastewater of households using laundry detergents that do not contain optical brighteners. Optical brighteners also photodecay (that is, degrade) when exposed to sunlight (Kramer and others, 1996) and, therefore, may not be present in effluents that have been exposed to sunlight or have undergone UV disinfection. Similarly, optical brighteners in groundwater that has discharged to surface waters will begin to degrade when exposed to sunlight.

\section{Sampling at Targeted Sites for Multiple Chemical Tracers of Wastewater}

For the final data-collection step, water samples are collected at targeted sites and then are analyzed at appropriate laboratories for chemical tracers of wastewater. Preparation efforts for the final data-collection step are substantial and include (1) selecting chemical tracers and laboratories, (2) selecting targeted sampling sites, (3) selecting sampling periods and conditions, (4) selecting sample-collection methods and equipment, (5) preparing a quality-assurance plan, and (6) obtaining and cleaning equipment.

\section{Selecting Chemical Tracers, Targeted-Sampling Sites, and Sampling Period}

The source-tracking approach proposes the use of the following chemical tracers of wastewater: nutrients, hydrogen 
Table 2. Worksheet template for recording fluorescence measurements and determining the presence or absence of optical brighteners in water samples.

[Tests 1, 2, and 3 modified from Cao and others (2009). Abbreviations: $\mu \mathrm{L}$, microliter(s); FL, measured fluorescence at 445-nanometer (nm) wavelength following excitation at 375-nm wavelength; L, liter(s); min, minute(s); UV, ultraviolet. Fluorescence measurements: initial FL, first, before exposure to UV light; FL-5, second, after 5 min exposure to UV light; FL-10, third, after additional 5 min (that is, after 10 min) exposure to UV light. Percent-reduction values: percent-5, percent reduction after $5 \mathrm{~min}$; percent-10, percent reduction after $10 \mathrm{~min}$ ]

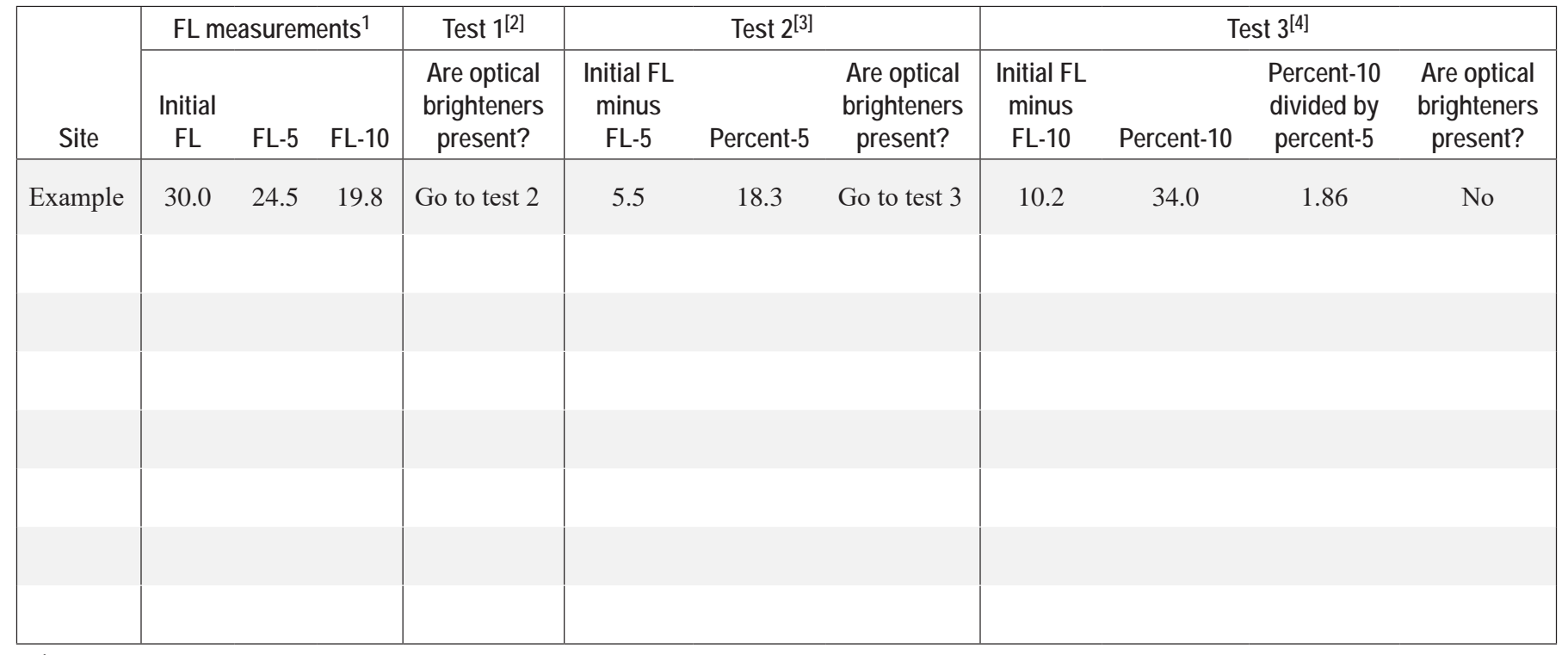

${ }^{1}$ If fluorescence was measured with fluorometer calibrated to 0 fluorescence units using deionized water and to 50 fluorescence units using prepared detergent solution $(50 \mu \mathrm{L}$ laundry detergent mixed in $1 \mathrm{~L}$ deionized water), then start with test 1 . Otherwise, start with test 2.

${ }^{2}$ If initial fluorescence is less than 5 (equivalent to detergent concentration of $5 \mu \mathrm{L} / \mathrm{L}$ ), then conclude that sample is negative for optical brighteners. Otherwise, proceed to test 2 .

${ }^{3}$ If reduction in fluorescence at 5-min UV-light exposure is less than 8 percent, then conclude that sample is negative for optical brighteners. If reduction is greater than or equal to 30 percent, then conclude that sample is positive for optical brighteners. Otherwise, proceed to test 3.

${ }^{4}$ If ratio of (1) percent reduction at 10-min UV-light exposure to (2) percent reduction at 5-min UV-light exposure is greater than or equal to 1.5, then conclude that sample is negative for optical brighteners. Otherwise, conclude that sample is positive for optical brighteners.

$(\mathrm{H})$ and oxygen $(\mathrm{O})$ isotopes in water, nitrogen $(\mathrm{N})$ and $\mathrm{O}$ isotopes in nitrate, organic-waste compounds, and pharmaceutical compounds. The manner in which these chemicals can be applied as wastewater tracers is explained in the section below entitled, "Evaluating Laboratory Results of Chemical Tracers of Wastewater." Most of these chemical tracers were used in each of the previous CWB-USGS source-tracking efforts in Hawai'i (fig. 2; table 1).

Reliable laboratories that are capable of analyzing for the chemical tracers in water samples are those that analyze samples according to published procedures, adhere to qualityassurance protocols, and meet the policies required by the investigators (see, for example, USGS, 2014). The USGS Reston Stable Isotope Laboratory (RSIL) in Virginia is capable of analyzing water samples for $\mathrm{H}$ and $\mathrm{O}$ isotopes in water and $\mathrm{N}$ and $\mathrm{O}$ isotopes in nitrate (table 3). The USGS National Water Quality Laboratory (NWQL) in Colorado is capable of analyzing water samples for nutrients, organic-waste compounds, and pharmaceutical compounds (table 3 ). Other, non-USGS laboratories also may be reliable and capable of analyzing for chemical tracers in water samples.
The NWQL currently (2020) analyzes whole-water samples for 69 organic waste compounds (table 4) using laboratory schedule 4433 and also filtered-water samples for 113 pharmaceutical compounds (table 5) using laboratory schedule 2440; NWQL currently (2020) does not allow samples to be analyzed for a subset of the chemical compounds in these two schedules. The organic-waste compounds analyzed at NWQL are ingredients and by-products of common agricultural, industrial, and household substances (Baldwin and others, 2015). The pharmaceutical compounds analyzed at NWQL are ingredients in pharmaceutical products and drugs used by humans.

To select targeted-sampling sites, investigators can use the same strategy used to select reconnaissance-sampling sites (see section above entitled, "Selecting and Inspecting Reconnaissance-Sampling Sites"), taking into account background information, the results of the trolling-instrument surveys, and results of the optical-brightener testing. To reduce the cost of source-tracking efforts, investigators can select fewer targeted-sampling sites than reconnaissance-sampling sites. Sampling a study area's source waters is critical because understanding source-water chemical signatures will help 
Table 3. Examples of laboratory methods capable of analyzing water for selected chemical tracers of wastewater.

[Abbreviations: USGS, U.S. Geological Survey; N, nitrogen; P, phosphorus; H, hydrogen; O, oxygen. Laboratories: NWQL, USGS National Water Quality Laboratory, Denver, Colo.; RSIL, USGS Reston Stable Isotope Laboratory, Reston, Va.]

\begin{tabular}{lllll}
\hline \multicolumn{1}{c}{ Type of analysis } & \multicolumn{1}{c}{ Medium analyzed } & USGS method & Laboratory & Reference \\
\hline Nitrogen, ammonia, as N & Filtered water & Lab code 3116 & NWQL & Fishman (1993) \\
Nitrogen, nitrite, as N & Filtered water & Lab code 3117 & NWQL & Fishman (1993) \\
Nitrogen, nitrite + nitrate, as N & Filtered water & Lab code 3156 & NWQL & Patton and Kryskalla (2011) \\
Total dissolved nitrogen, as N & Filtered water & Lab code 2754 & NWQL & Patton and Kryskalla (2003) \\
Orthophosphate, as P & Filtered water & Lab code 3118 & NWQL & Fishman (1993) \\
Phosphorus, as P & Filtered water & Lab code 2331 & NWQL & Fishman (1993) \\
Pharmaceutical compounds & Filtered water & Schedule 2440 & NWQL & Furlong and others (2014) \\
Organic-waste compounds & Whole water & Schedule 4433 & NWQL & Zaugg and others (2007a) \\
Stable isotopes of H, O in water & Filtered or whole water & Lab code 1142 & RSIL & Révész and Coplen (2008a, b) \\
Stable isotopes of N, O in dissolved nitrate & Filtered water & Lab code 2900 & RSIL & Coplen and others (2012)
\end{tabular}

investigators interpret the chemical signatures of samples that are mixtures of source waters.

Cost constraints often limit the number of sites sampled. To manage costs, investigators can consider being selective in the types of chemicals that are analyzed in water samples from each sampling site. During USGS source-tracking efforts on Maui, Hunt and Rosa (2009) had samples from all targeted sites analyzed using inexpensive analytical procedures (those for nutrients, stable isotopes in water, and stable isotopes in nitrate), and they also had samples from a subset of the targeted sites analyzed using more costly analytical procedures (those for organic-waste and pharmaceutical compounds). Note, however, that chemical-tracer results from the relatively expensive analytical procedures are likely to be more reliably diagnostic of wastewater presence or absence.

Next, the conditions and frequency for collecting samples are determined. For example, samples could be collected during storm conditions (after heavy rainfall), dry-weather conditions, or both. Hunt (2014) collected two rounds of samples (one wet-season round and one dry-season round) at targeted sites near Kaloko-Honokōhau, Hawai' $i$ Island. For most of the previous source-tracking efforts conducted by CWB and USGS in Hawai' ${ }^{\circ}$ (fig. 2), only one round of samples was collected at one set of targeted sites; the sets of sites ranged from less than a dozen to a few dozen sites.

\section{Selecting Sample-Collection Methods and Equipment}

The parts of sampling equipment through which water flows must be constructed of materials that are least likely to alter the chemistry of the sampled water. For the proposed source-tracking efforts in which water samples will be analyzed for inorganic chemicals (nutrients, stable isotopes in water, and stable isotopes in nitrate) and organic chemicals (pharmaceutical and organic-waste compounds), the sampling equipment should be constructed of either glass or fluorocarbon polymers such as Teflon (Wilde and others, 2014). Stainless steel submersible pumps also can be used to collect groundwater samples. Pumps that contain corroded steel, however, should not be used because organic compounds tend to sorb to corroded metal surfaces (Wilde and others, 2014).

Examples of sampling methods used previously by USGS personnel to collect samples at different types of sites in Hawai ${ }^{\circ} \mathrm{i}$ are shown in figures 4 and 5 (see also, section above entitled "Selecting Reconnaissance-Sample-Collection Methods and Equipment"). In general, the sampling methods for reconnaissance sampling also can be used for targeted sampling.

For surface-water sites that have flowing water, however, investigators likely will consider using isokinetic sampling methods (that is, water approaching and entering the sampler intake does not change in velocity) instead of the nonisokinetic sampling methods (dip, discrete, pump, and stage level) described for reconnaissance-sampling efforts. The collection of depth-integrated, discharge-weighted samples using isokinetic samplers is considered by the USGS field manual (USGS, 2006) to be the standard sampling method for flowing-water sites. Isokinetic sampling methods use complex sampling devices that are designed to accumulate a representative water sample continuously and isokinetically from a vertical section of a wetted channel while transiting the vertical at a uniform rate (Wilde and others, 2014). In contrast, the nonisokinetic sampling methods use basic sampling devices in which water enters at a velocity that differs from the ambient velocity of the stream.

Isokinetic sampling methods (described in USGS, 2006) require trained field personnel. For example, one sampling 
Table 4. Organic-waste compounds analyzed in water samples by the U.S. Geological Survey National Water Quality Laboratory.

[Abbreviations: $\mu \mathrm{g} / \mathrm{L}$, micrograms per liter; BDE, brominated diphenyl ether; PAH, polycyclic aromatic hydrocarbon; USGS, U.S. Geological Survey. Organicwaste compounds in red are considered by Baldwin and others (2016) to be indicators of domestic wastewater from sanitary-sewer sources]

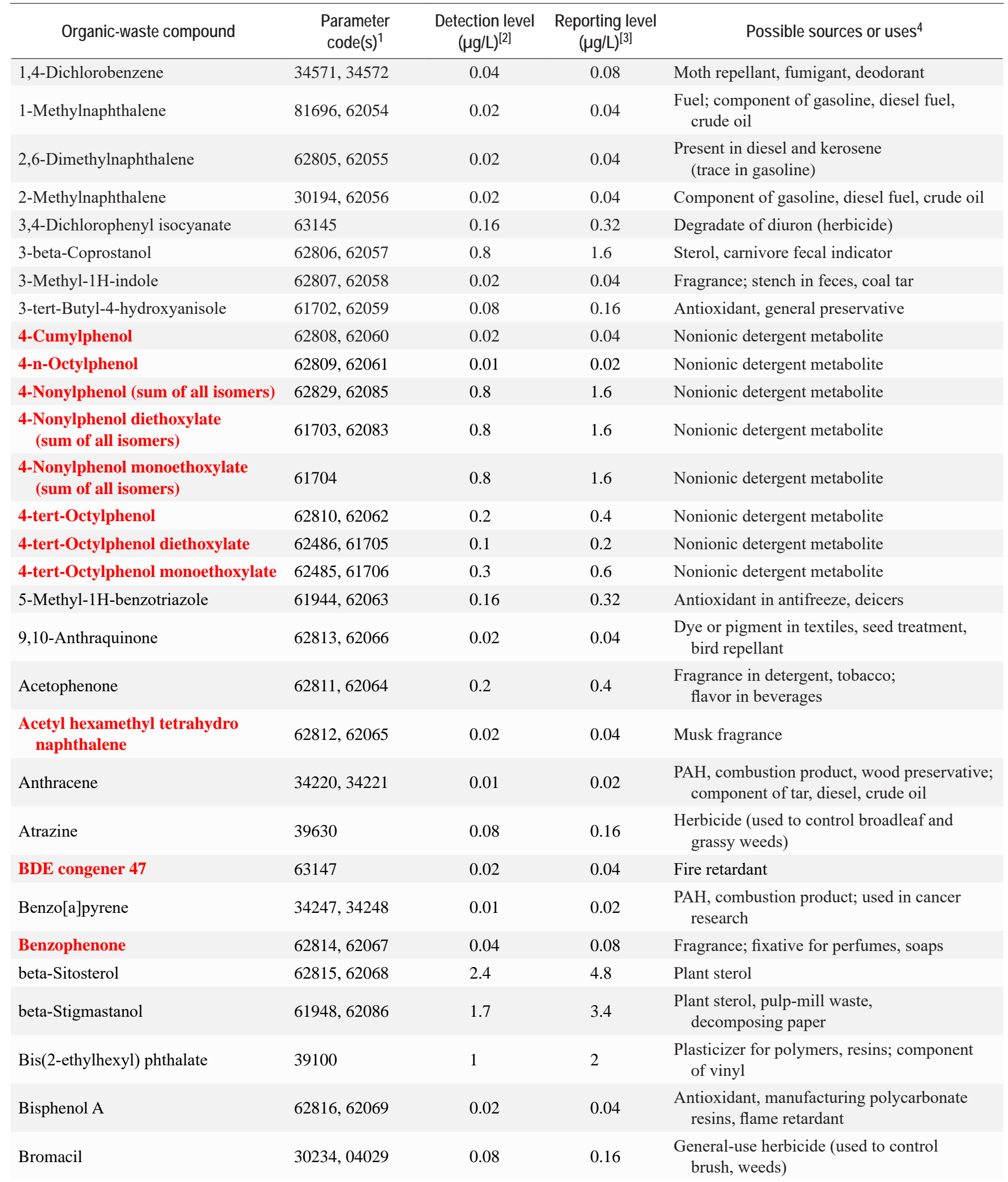


Table 4. Organic-waste compounds analyzed in water samples by the U.S. Geological Survey National Water Quality Laboratory.-Continued

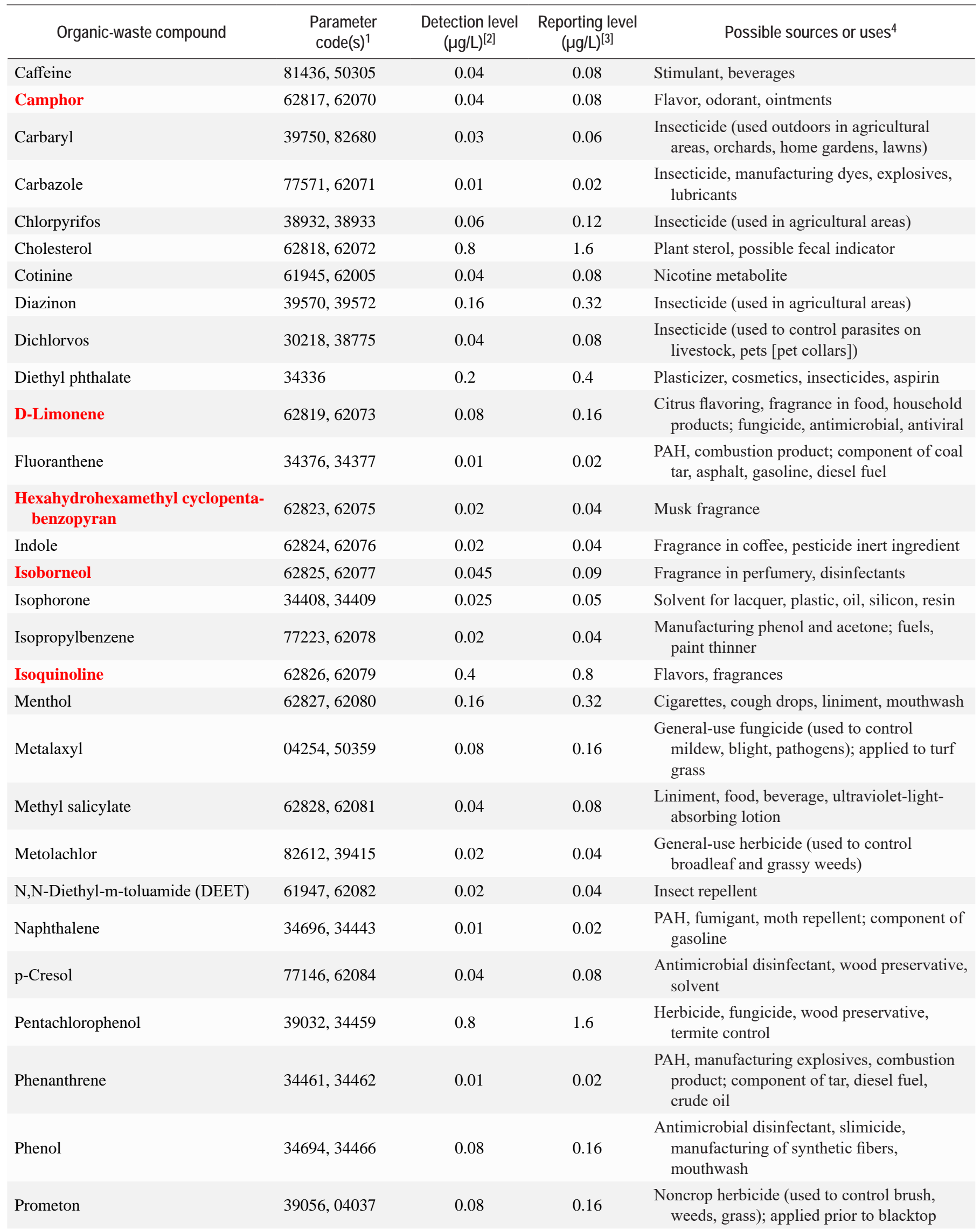


Table 4. Organic-waste compounds analyzed in water samples by the U.S. Geological Survey National Water Quality Laboratory.-Continued

\begin{tabular}{|c|c|c|c|c|}
\hline Organic-waste compound & $\begin{array}{l}\text { Parameter } \\
\text { code }(s)^{1}\end{array}$ & $\begin{array}{l}\text { Detection level } \\
\qquad(\mu \mathrm{g} / \mathrm{L})^{[2]}\end{array}$ & $\begin{array}{l}\text { Reporting level } \\
\qquad(\mu \mathrm{g} / \mathrm{L})^{[3]}\end{array}$ & Possible sources or uses 4 \\
\hline Pyrene & 34469,34470 & 0.01 & 0.02 & $\begin{array}{l}\text { PAH, combustion product; component of coal } \\
\text { tar, asphalt, gasoline, diesel fuel }\end{array}$ \\
\hline Tetrachloroethene & 34475,34476 & 0.08 & 0.16 & Solvent, degreaser, veterinary anthelmintic \\
\hline Tribromomethane & 32104, 34288 & 0.08 & 0.16 & $\begin{array}{l}\text { Wastewater disinfection byproduct, military } \\
\text { and explosives, naturally produced by } \\
\text { macroalgae }\end{array}$ \\
\hline Tributyl phosphate & 62832, 62089 & 0.032 & 0.064 & Fire retardant, antifoaming agent \\
\hline Triclosan & 61708,62090 & 0.16 & 0.32 & Antimicrobial disinfectant \\
\hline Triethyl citrate & 62833, 62091 & 0.02 & 0.04 & Plasticizer, cosmetics, pharmaceuticals \\
\hline Triphenyl phosphate & 62834, 62092 & 0.04 & 0.08 & $\begin{array}{l}\text { Plasticizer, resin, wax, finish, roofing paper, } \\
\text { flame retardant }\end{array}$ \\
\hline Tris(dichloroisopropyl) phosphate & 61707, 62088 & 0.16 & 0.32 & Fire retardant \\
\hline
\end{tabular}

${ }^{1}$ Parameter codes used by USGS National Water Information System (where analytical results are stored and can be accessed): first parameter code shown is used for results of whole-water samples collected by USGS in Hawai'i after 2004 and analyzed using methods in Zaugg and others (2007a); second parameter code shown (if any) is used for results of filtered-water samples collected by USGS in Hawai' $i$ in 2004 and analyzed using methods in Zaugg and others (2007b).

${ }^{2}$ Detection level as of June 19, 2019.

${ }^{3}$ Reporting level as of June 19, 2019.

${ }^{4}$ Modified from Zaugg and others (2007a) and Baldwin and others (2016). 
Table 5. Human-use pharmaceutical compounds analyzed in filtered-water samples by the U.S. Geological Survey National Water Quality Laboratory.

[Abbreviations: n/a, not available; ng/L, nanograms per liter; USGS, U.S. Geological Survey]

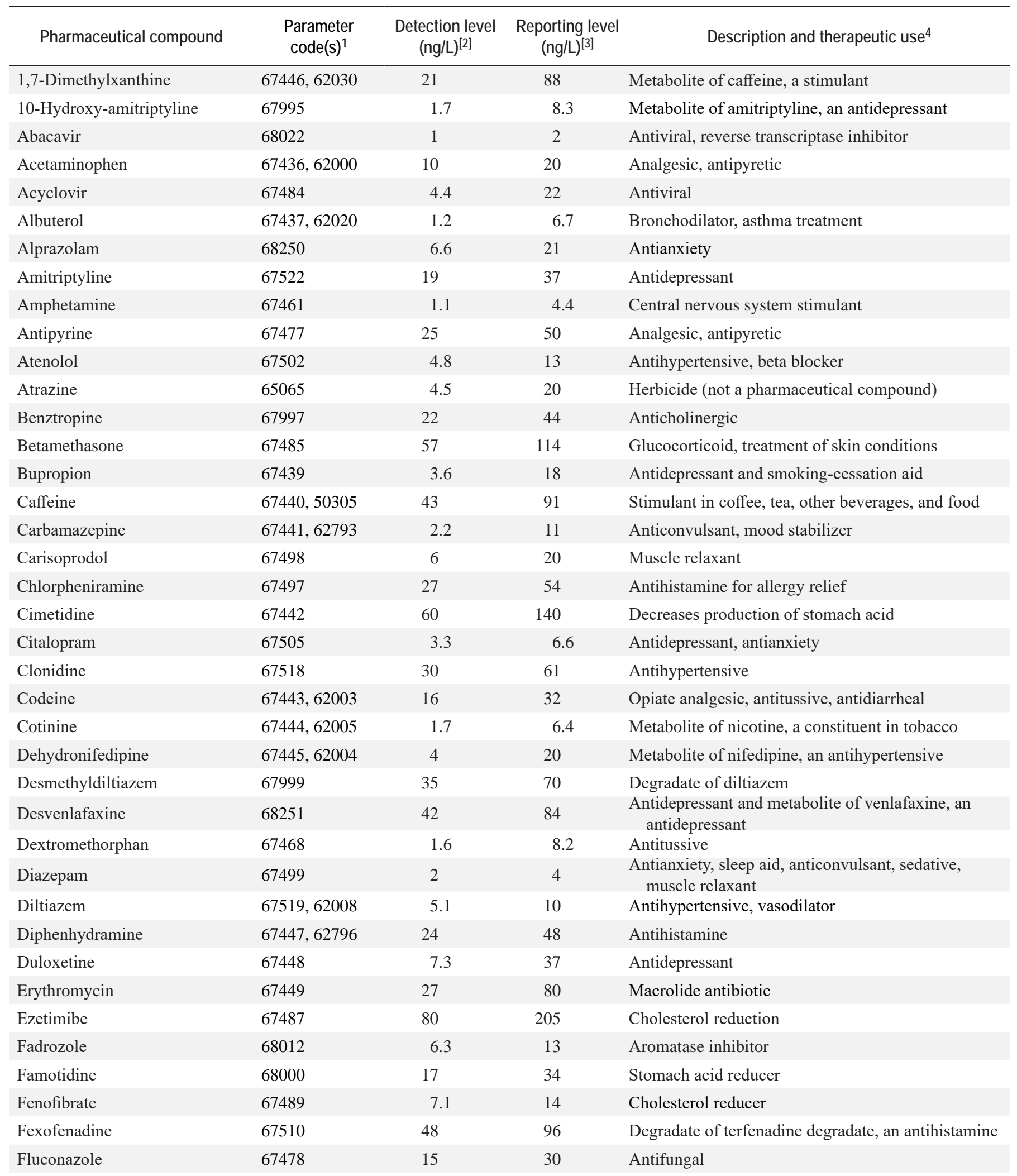


Table 5. Human-use pharmaceutical compounds analyzed in filtered-water samples by the U.S. Geological Survey National Water Quality Laboratory.-Continued

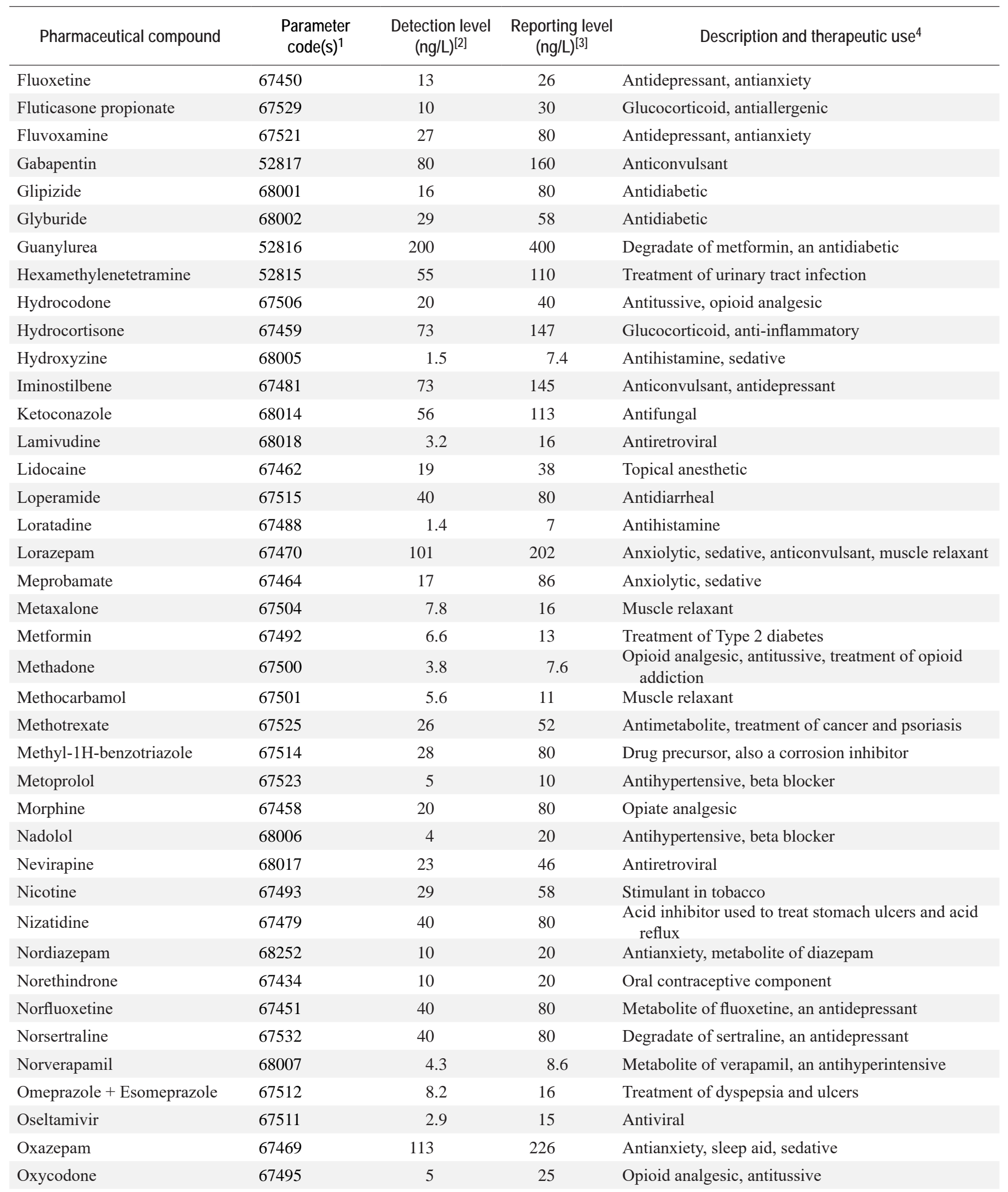


Table 5. Human-use pharmaceutical compounds analyzed in filtered-water samples by the U.S. Geological Survey National Water Quality Laboratory.-Continued

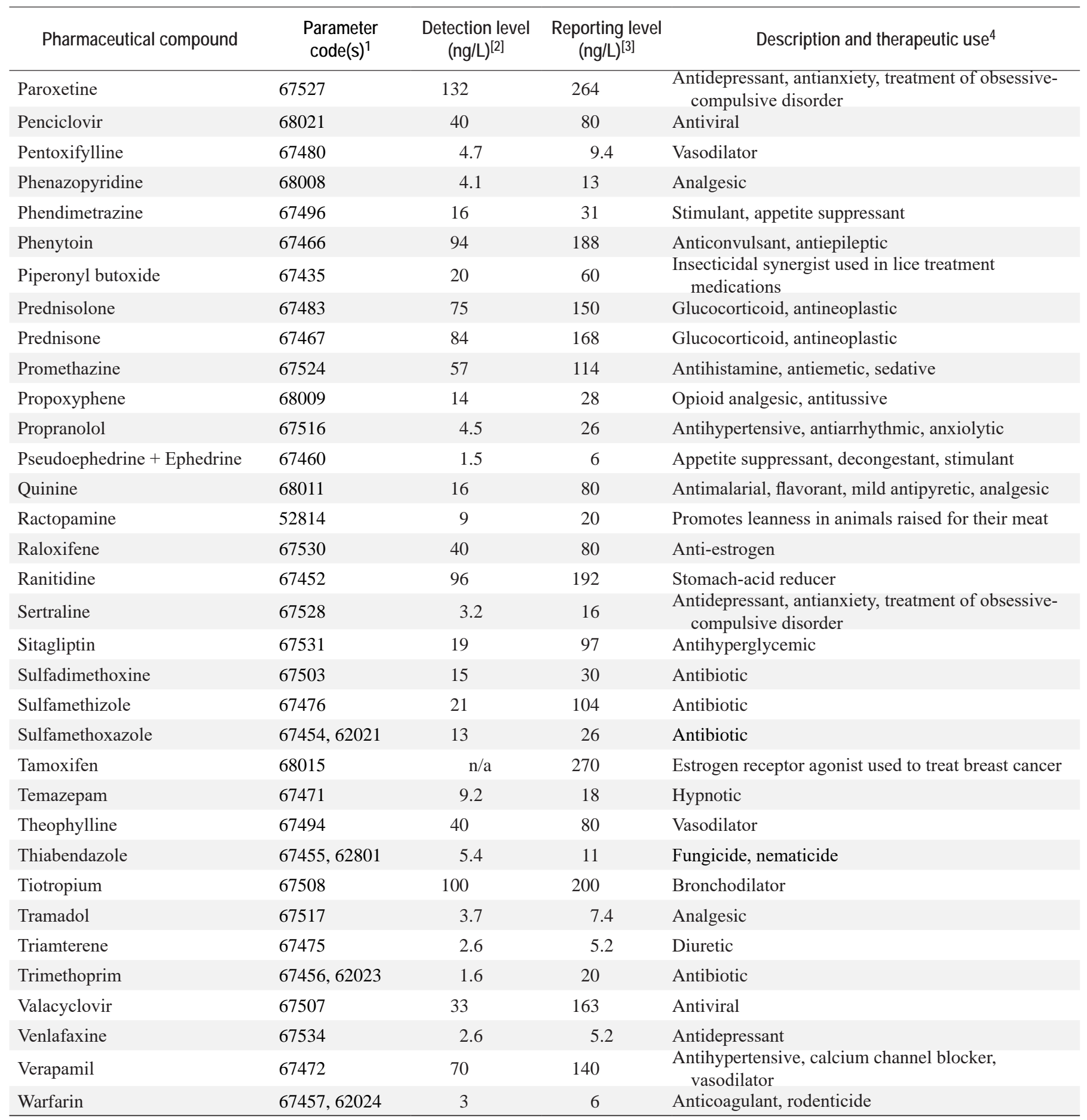

${ }^{1}$ Parameter codes are used by USGS National Water Information System, where analytical results are stored and can be accessed: first parameter code shown is used for results of samples collected by USGS in Hawai' $i$ after 2012 and analyzed using methods described in Furlong and others (2014); second parameter code shown (if any) is used for results of samples collected by USGS in Hawai'i between 2008 and 2012 and analyzed using methods described in Furlong and others (2008).

${ }^{2}$ Detection level as of June 19, 2019.

${ }^{3}$ Reporting level as of June 19, 2019.

${ }^{4}$ Modified from Furlong and others $(2014,2017)$ and Romanok and others (2018). 
method that uses isokinetic samplers is the equal-widthincrement method, for which the stream cross section is subdivided into multiple increments having a specified width. Isokinetic samplers collect water while being lowered and raised by field personnel at an appropriate rate within each increment. The collected water typically is composited by field personnel using a churn splitter, from which water is eventually extracted for processing. The collection of samples in this manner can be time consuming and often will limit the number of samples that can be collected by a field team on a given day. In contrast, nonisokinetic sampling methods such as dip and discrete sampling are straightforward and can be used by field personnel to collect samples from numerous sites relatively quickly.

Analytical results for water samples collected using isokinetic, depth- and width-integrating sampling methods might be more representative of conditions at a flowingsurface-water site than those for samples collected using nonisokinetic sampling methods, especially if target analytes (chemical tracers of wastewater) are not uniformly distributed in the site's wetted cross section. Therefore, investigators may have greater confidence in interpretations made from results of samples that were collected using isokinetic methods than in those from nonisokinetic sampling methods. If, however, the use of isokinetic sampling equipment and associated sampling methods is not feasible owing to constraints such as the need to collect samples from several locations within a short period or the limited availability of appropriate equipment and trained field personnel, then nonisokinetic sampling methods can be considered. Nonisokinetic sampling methods are considered potentially acceptable for use in the source-tracking approach because the chief objective of this approach is to assess the occurrence and distribution of wastewater in the study area on the basis of the occurrence and distribution of chemical tracers of wastewater at sampling sites. If nonisokinetic sampling methods are used, then field personnel can attempt to collect water at multiple locations along a site's cross section, rather than at the centroid of flow only. In most bodies of flowing water, a single sampling point is not adequate to describe the distribution and abundance of chemical constituents at the site (USGS, 2006).

If any sampling equipment will be reused for more than one sample, field personnel must clean the equipment between samples to minimize cross contamination. Because cleaning equipment in the field can be time consuming, field personnel ought to consider preparing a clean set of sampling equipment for each sample in advance. If field cleaning is necessary, plan to collect additional field blanks with the field-cleaned equipment.

\section{Preparing a Quality-Assurance Plan}

A quality-assurance plan prepared by investigators will document the quality of their sampling results. The qualityassurance plan can include (1) equipment-cleaning procedures, (2) quality-assurance procedures to be followed by field personnel to prevent sample contamination, and (3) a sampling plan for quality-control samples. The procedures used to collect, process, and analyze all samples for chemical tracers can be summarized in the quality-assurance plan. Adherence to the quality-assurance plan will improve investigators' confidence in their sampling results and interpretations.

Clean sample-collection and -processing equipment must be used for source-tracking efforts. Equipment-cleaning procedures to be used by field personnel are defined in the quality-assurance plan. Detailed descriptions of cleaning procedures and cleaning solutions used by USGS personnel are provided in Wilde (2004). Briefly, reusable equipment (submersible pumps, reusable sample tubing, and reusable sample-collection bottles) that will be used to collect samples to be analyzed for the suite of proposed chemical tracers is cleaned using the following steps: (1) wash and soak all equipment in a dilute nonphosphate-soap solution, (2) rinse all equipment with tap water, (3) soak metal-free equipment in a dilute hydrochloric acid solution, (4) rinse all equipment with deionized water, (5) rinse all equipment with methanol, and (6) air-dry or rinse all equipment with pesticide-grade organic blank water.

Field personnel who clean equipment, collect samples, and (or) process samples are a potential source of sample contamination. Lewis and Zaugg (2003) described how field personnel can prevent contamination of samples to be analyzed for organic-waste and pharmaceutical compounds, as these samples are especially vulnerable to contamination. Briefly, field personnel must wear nitrile gloves when handling sampling and processing equipment while they clean equipment, collect samples, and process samples. A clean set of gloves should be worn with each change in activity during each of these efforts. Field personnel handling equipment must use clean hands/dirty hands techniques (see fig. 9; see also, Skrobialowski, 2016) to reduce the chance of contaminating water samples. On days when equipment is being cleaned and (or) when samples are being collected and processed, field personnel should minimize contact with, or consumption of, products containing certain chemicals (tables 4, 5), as well as refrain from using fragrances, soaps, detergents, antibacterial cleansers, caffeine, tobacco, sunscreen, and insect repellent with N,N-Diethylm-toluamide (DEET). Field personnel also should avoid breathing directly over open samples and equipment, and they should not allow their skin, hair, or clothing to contact any sampling or processing equipment.

\section{Planning for the Collection and Analysis of Quality-Control Samples}

The quality-assurance plan ideally will include a sampling plan for collecting quality-control (QC) samples, which include blanks, replicates, and spikes. Blanks are used to estimate bias caused by contamination; replicates are used to evaluate variability in analytical results; and spikes are used to determine the performance of analytical methods and to estimate the potential bias resulting from matrix interference 


\section{CLEAN HANDS / DIRTY HANDS TECHNIOUES when collecting water-quailty samples}

- Clean hands/dirty hands techniques require two or more people working together

- At the sample-collection site, designate one person as clean hands $(\mathrm{CH})$ and a second as dirty hands (DH)

- Although specific tasks are assigned to $\mathrm{CH}$ or $\mathrm{DH}$, some tasks overlap and can be handled by either person, as long as care is taken to prevent contaminating the sample

- $\mathrm{CH}$ and DH must wear disposable, powderless, nitrile gloves during the entire sampling operation, and they should change gloves frequently, usually with each change in task. Wearing multiple layers of gloves allows rapid glove changes

\section{$\mathrm{CH}$ takes care of all operations involving equipment that contacts the sample}

- Handles the surface-water sampler bottle

- Handles the ends of all tubing used to collect samples

- Handles the bag inside churn carrier that covers the churn

- Transfers water from sampler bottle to the churn

- Handles all cleaning equipment in the field

- Cleans sampling equipment in the field

\section{DH takes care of all operations involving contact} with potential sources of contamination

- Operates support equipment, such as vehicles, drills, and tripods

- Handles power supply equipment, such as pump-control units

- Handles tools, such as drills, drill attachments, hammers, wrenches, keys, and locks

- Handles and calibrates instruments used for field measurements

- Measures and records field measurements, such as temperature and specific conductance

- Records sample information, such as date, time, and environmental conditions

- Prepares and operates sampling equipment, including pumps, weighted bottle holders, and water-flow manifold systems

- Avoids touching the ends of tubing used to collect samples

- Handles the churn carrier and bags covering outside of churn carrier

Figure 9. Lists of clean hands/dirty hands techniques to follow when collecting water-quality samples to be analyzed for chemical tracers of wastewater (note that Skrobialowski [2016] described clean hands/dirty hands techniques to follow when processing water-quality samples at groundwater and surface-water sites). Modified from USGS (2006). 
or analyte degradation (Mueller and others, 2015). The numbers and types of QC samples to collect depends on the project scope, study area, and other factors. Mueller and others (2015) provided guidance on developing a sampling plan for QC samples, on collecting various QC samples, and on analyzing and interpreting the results.

The collection of blanks is critical for the source-tracking approach. Blank samples are prepared with blank water that is intended to be free of measurable concentrations of the chemicals to be analyzed by the laboratories (Mueller and others, 2015). Each blank sample consists of blank water that has passed sequentially through each component of the samplecollection and -processing equipment. USGS personnel use specific types of blank water that have been quality assured by NWQL. Inorganic blank water can be used for blank samples that will be analyzed only for nutrients. Pesticide-grade organic blank water is used for blank samples that are tested for organic-waste or pharmaceutical compounds; it also can be used for blank samples that will be analyzed for nutrients. Blanks usually are not analyzed for stable isotopes in water or nitrate.

Equipment blanks and field blanks are two types of blank samples that investigators collect during source-tracking efforts. Equipment blanks are intended to demonstrate that sample-collection equipment, processing equipment, and equipment-cleaning efforts are not sources of contamination (Mueller and others, 2015). An equipment blank is collected and processed under controlled conditions in the workplace laboratory, after sample-collection and sample-processing equipment have been cleaned. One equipment blank is collected at least several months before sampling efforts commence so that the equipment-blank results can be reviewed and any corrective actions can be implemented early in the study. The equipment blank is analyzed for the same chemicals that will be analyzed in water samples to be collected at targeted sites. If the equipment-blank results indicate that the equipment does not introduce chemicals that will bias study results, then sampling efforts can proceed. If, however, any chemicals of interest are detected in the equipment blank at unacceptably high concentrations, then the source of the chemicals must be identified and the equipment or cleaning procedures must be changed or modified before sampling efforts can proceed. Alternatively, if only one or a few chemical tracers is detected in the equipment blank, then the investigator may consider omitting the use of those particular chemical tracers in their source-tracking efforts.

Field blanks are intended to document the frequency and magnitude of contamination in environmental-water samples (Mueller and others, 2015). A field blank is collected and processed in the field at a sampling site in the same manner as environmental samples. Past USGS-CWB source-tracking efforts in Hawai'i usually included the collection of a field blank at one site for each round of sampling; investigators used the results of the field blank to infer potential contamination for samples collected during the same day or week at other sites in a similar setting using similar equipment and sampling procedures.

For selected chemical tracers (nutrients, pharmaceutical compounds, and organic-waste compounds), the results for field blanks are examined, and the value qualifiers, comments, and remarks are added to the results by the laboratory. Ideally, none of these chemical tracers are detected in field blanks or in laboratory blanks (which are blanks prepared by the laboratory); if that is the case, chemical contamination from equipment, field personnel, laboratory personnel, and the environment can be considered negligible. If, however, a chemical is detected in a field blank or laboratory blank at a concentration that is similar to, or greater than, the chemical's concentrations in some of the environmental-water samples, then investigators will need to decide which, if any, of their sample results for that chemical can be used to make interpretations.

Investigators ideally would aim to collect at least one replicate for each sampling period. For example, if one set of samples is collected during fair-weather conditions and a second set is collected during storm conditions, then investigators would aim to collect at least one replicate for each set of samples.

\section{Preparing for Sample Collection and Processing}

The first step in preparing for sample collection and processing is to obtain the current processing (filtration) and preservation instructions from the laboratories that will analyze water samples. Current (2020) procedures used to process samples for the proposed chemical tracers at NWQL and RSIL are described in the section below entitled, "Collecting and Processing of Water Samples."

Obtain and clean all sample-collection equipment.All sample-collection equipment should be cleaned using the cleaning procedures defined in the quality-assurance plan. If feasible, a clean set of equipment is prepared for each site to be sampled on a given day to lessen the chance of cross contamination between sites and to eliminate the need for time-consuming equipment-cleaning efforts in the field. If more than one sample will be collected at a site on a given day, a clean set of equipment can be prepared for each sample. After cleaning the equipment, equipment orifices are covered with aluminum foil or fluorocarbon polymer bags, and then the equipment is placed into sealable bags for storage and transport.

Obtain all processing equipment.-The filters and syringes used to process samples, as well as the bottles that will store processed water, are purchased new, and they should meet the requirements of the analyzing laboratories. For example, polyethylene bottles that will store filtered water to be analyzed for nutrients at NWQL and isotopes in dissolved nitrate at RSIL need to be triple rinsed with deionized water. Flexible tubing, typically used during the filtration of water samples for nutrients and isotopes in nitrate, needs to be cleaned using the cleaning procedures 
defined in the quality-assurance plan. Glass bottles that will store water to be analyzed for organic-waste compounds and pharmaceutical compounds can be purchased in ready-to-use condition (cleaned, baked, and tightly capped), and so they are not cleaned or rinsed by field personnel. RSIL can provide investigators with glass bottles to store water to be analyzed for $\mathrm{H}$ and $\mathrm{O}$ isotopes in water, and these bottles should not be rinsed. Any processing equipment that will be reused will need to be cleaned using the procedures defined in the qualityassurance plan.

Plan the sequential order in which sites will be sampled.-If feasible, investigators should plan to start at relatively pristine sites (that is, the ones that are expected to have the lowest concentrations of chemical tracers). By starting at relatively pristine sites, field personnel can reduce the risk of contaminating equipment and samples. Then they can end at sites that are expected to have the highest concentrations of chemical tracers and, thus, the greatest potential for contamination. For example, they could start at the ambient freshwater site and end at a site downstream from dense residential areas that have cesspools.

Decide whether to process samples immediately at each of the field sites, or later in batches.-Samples collected at groundwater sites usually are processed at the field site. However, samples collected at several surface-water sites on a given day could be double bagged and stored in ice-filled coolers and then processed in a clean workspace at the end of each workday.

Other preparations.-Other preparations include printing bottle labels; obtaining sample-submission forms required by the laboratories; ensuring that laboratory results will be loaded into a database; gathering safety equipment such as reflective vests, chest waders, and personal flotation devices; and acquiring a field notebook, tablet, or laptop computer with which sample information and field measurements of physical properties can be recorded.

\section{Collecting and Processing Water Samples}

Once sampling preparations are complete, water samples can be collected using the selected equipment and methods at the targeted sites during the targeted periods and environmental conditions. Field personnel must use the clean hands/dirty hands techniques during sample collection (fig. 9). Water temperature, SC, and other physical properties of interest can be measured using appropriately calibrated instruments, and results are recorded at each site during sample collection. If dedicated sets of equipment for each site are not available, reusable equipment is cleaned before moving to the next sampling site.

Water samples should be processed in a mostly enclosed processing chamber to minimize contamination from the atmosphere and from field personnel. The processing chamber consists of a clean bag, the outside of which is attached to a box-shaped frame using clips (see for, example, fig. 6B).
Water samples should be processed according to current requirements of the selected analyzing laboratories, as the following examples show:

- Water to be analyzed for nutrients at NWQL using laboratory schedule 2752 is filtered through a $0.45-\mu \mathrm{m}$ capsule filter (using the procedures described in Skrobialowski, 2016) and then is stored in a 125-mL brown polyethylene bottle that has been rinsed with filtered water.

- Water to be analyzed for pharmaceutical compounds at NWQL is processed using the methods and equipment described in Sandstrom and Wilde (2014).

- Water to be analyzed for organic-waste compounds at NWQL using laboratory schedule 4433 is not filtered but is stored in new 1-L amber glass bottles, as described in Zaugg and others (2007a).

- Water to be analyzed for $\mathrm{N}$ and $\mathrm{O}$ isotopes in dissolved nitrate at RSIL is filtered through a $0.45-\mu \mathrm{m}$ capsule filter and into a $125-\mathrm{mL}$ brown polyethylene bottle that has a cone-lined cap; these samples require a second filtration step that typically can be completed at RSIL upon request.

- Water to be analyzed for $\mathrm{H}$ and $\mathrm{O}$ isotopes in water at RSIL can be either filtered or unfiltered, and it is stored in the $60-\mathrm{mL}$ glass bottles provided by RSIL.

Processed samples should be labeled and preserved according to instructions from the analyzing laboratories. For example, processed samples to be analyzed at NWQL for nutrients (laboratory schedule 2752), pharmaceuticals (laboratory schedule 2440), and organic-waste compounds (laboratory schedule 4433) must be kept chilled until analysis. Processed samples to be analyzed at RSIL for $\mathrm{N}$ and $\mathrm{O}$ isotopes in dissolved nitrate must be frozen and held until nitrate results are available; note that isotopic compositions of dissolved nitrate cannot be reliably determined for samples that have nitrate concentrations that are less than the laboratory threshold (at RSIL, currently 0.06 milligrams per liter [mg/L] as N). Water to be analyzed at RSIL for $\mathrm{H}$ and $\mathrm{O}$ isotopes does not require chilling or preservation but must be stored in a $60-\mathrm{mL}$ glass bottle that has a tightened cap, which has a conical insert to prevent evaporation.

It is important to ensure that samples are received by the laboratories with enough time to allow them to be analyzed within the time limits (holding times) set by the laboratories for each analytical method. For sets of samples that must be kept chilled and need to be shipped in ice-filled chests, it is important to choose a shipping method and shipment date that ensures that the samples arrive chilled at the laboratories. Certain chemical tracers in a water sample may degrade if the sample is not kept chilled, and this could add uncertainty to the conclusions investigators formulate as they evaluate laboratory results. 


\section{Evaluating Laboratory Results of Chemical Tracers of Wastewater}

This section contains descriptions of approaches that can be used to evaluate the results of chemical analyses. It also contains general information needed to understand results of chemical analyses. The reporting conventions of selected USGS laboratories (NWQL, RSIL) are used in this section.

\section{Nutrients}

Laboratory results for nutrients (ammonia, nitrate, nitrite, and orthophosphate) are reported by NWQL as concentrations in $\mathrm{mg} / \mathrm{L}$, approximately equal to parts per million. Concentrations are reported as either detections (at the numeric value shown) or nondetections (as "less than" $[<]$ values, usually followed by the laboratory reporting level).

Investigators attempting to determine whether wastewater is present in their study area could determine whether the water samples are enriched in nutrients relative to nutrient concentrations in ambient freshwater and ocean water because nutrient enrichment is a supporting indicator of wastewater presence. If all samples are predominantly freshwater, then the amount of nutrient enrichment in each sample can be calculated as the difference in nutrient concentrations between the sample and ambient freshwater. Positive differences indicate nutrient enrichment, and negative differences indicate nutrient depletion.

If SC measurements indicate that some samples contain ocean water, then investigators can attempt to determine nutrient enrichment from a binary $(x-y)$ mixing plot for each nutrient, the nutrient concentrations being plotted on the vertical $(y)$ axis and the SC measurements being plotted on the horizontal $(x)$ axis (see, for example, fig. 10). In each plot, a hypothetical mixing line is drawn between the point for ambient freshwater and the point for ocean water. If ambient freshwater and ocean water were not sampled or analyzed for nutrients and SC, investigators could use published results for appropriate samples collected by others. Samples that plot along or near the mixing line are consistent with mixing between ambient freshwater and ocean water. Samples that plot above the line are interpreted as being enriched in the nutrient above background concentrations; that is, the nutrient has been added from some source in comparison to simple mixing of the source waters at the end points of the mixing line. Samples that plot below the line are interpreted as being depleted in the nutrient; that is, the nutrient has been removed by some mechanism. The amount of enrichment or depletion in a sample can be expressed in concentration units above or below the nutrient concentration predicted by the mixing line at the sample's SC value (fig. 10). Enrichment and depletion values

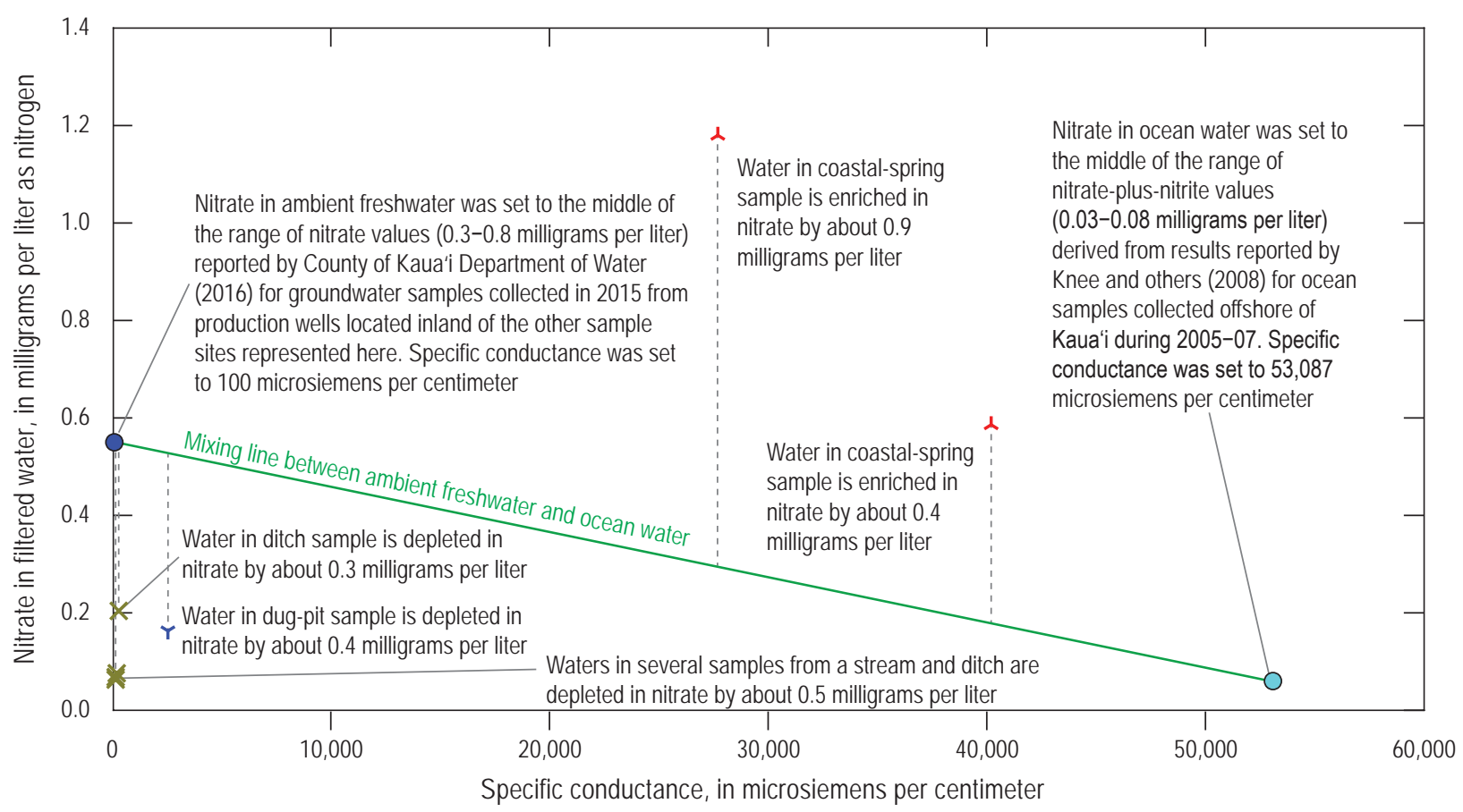

Figure 10. Mixing plot used to determine whether water samples collected near Māhā'ulepū, Kaua'i, are enriched or depleted in nitrate, relative to mixing line between ambient freshwater and ocean water. Unless otherwise noted, results are for samples collected near Māhā'ulepū, Kaua'i, during fair-weather conditions in 2015 (data for these samples are available from U.S. Geological Survey National Water Information System [USGS, 2016]). 
calculated for nitrate will help investigators evaluate results of $\mathrm{N}$ and $\mathrm{O}$ isotopes in dissolved nitrate (see section below entitled, "Nitrogen and Oxygen Isotopes in Dissolved Nitrate").

Figure 10 shows how a mixing plot can be used to determine whether water samples collected by CWB-USGS at several sites near Māhā'ulepū, Kaua'i, in 2015 are enriched or depleted in nitrate, relative to nitrate concentrations predicted by a mixing line drawn between the values assumed for ambient freshwater and ocean water. Nitrate values for the mixing line were derived from a drinking-water-quality report (County of Kaua'i Department of Water, 2016) for the area and from Knee and others (2008). The two coastal springs are interpreted as being enriched in nitrate, whereas the dug-pit, stream, and ditch samples are interpreted as being depleted in nitrate.

For context, nutrient concentrations in coastal ocean water samples collected in Hawai' ${ }^{\circ}$ (available in NWIS [USGS, 2016] as of May 2019) that were at least 95 percent ocean water (that is, measured SC exceeded 50,433 microsiemens per centimeter) ranged from 0.017 to 0.061 $\mathrm{mg} / \mathrm{L}$ as $\mathrm{N}$ for nitrate plus nitrite and from 0.005 to 0.014 $\mathrm{mg} / \mathrm{L}$ as $\mathrm{P}$ for orthophosphate. These ranges describe results for seven coastal ocean water samples collected in Maui in 2008: one of the samples was collected near Kîhei, and six were collected near Lahaina. These ranges could potentially be used to guide characterization of ocean water in mixing plots to evaluate nutrient results for samples collected during future source-tracking efforts. Concentrations of nitrate exclusive of nitrite were not measured in the seven samples. For the mixing plots, however, investigators potentially could assume that concentrations of nitrate plus nitrite in ocean water are similar to concentrations of nitrate in ocean water because most fixed nitrogen in the ocean is nitrate (Zakem and others, 2018), as was assumed for the mixing plot shown in figure 10.

Although samples enriched in one or more nutrients can serve as supporting indicators of wastewater, nutrient enrichment alone is not diagnostic of wastewater presence. Waters affected by fertilizers and animal fecal matter also may be enriched in nutrients. Lack of nutrient enrichment in sampled waters may not be indicative of wastewater absence. Processes that reduce nutrient concentrations in water include denitrification of nitrate to nitrogen gas and uptake (assimilation) of nitrate and orthophosphate by aquatic organisms. Also, phosphate tends to sorb to goethite and other iron and aluminum oxides and hydroxides (Parfitt and others, 1975; Fox and Searle, 1978; McLaughlin and others, 1981; Barron and others, 1988) that are common in Hawaiian soils.

This approach for determining whether samples are enriched in nutrients has some limitations. First, it is assumed that investigators selected the appropriate source waters to define the nutrient mixing line or lines between source waters (for example, fig. 10). Second, it is assumed that each selected source water has temporally constant nutrient concentrations. The validity of the second assumption can be investigated by examining records of nutrient concentrations in the source waters. For example, if groundwater from public drinkingwater-supply wells is used to represent ambient freshwater, then long-term records of nitrate concentrations in groundwater may be available at water-provider agencies such as county water departments.

\section{Stable Isotopes}

Isotopes are atoms of the same element that have different numbers of neutrons: hydrogen has two stable isotopes $\left({ }^{1} \mathrm{H}\right.$, $\left.{ }^{2} \mathrm{H}\right)$; nitrogen has two $\left({ }^{14} \mathrm{~N},{ }^{15} \mathrm{~N}\right)$; and oxygen has three $\left({ }^{16} \mathrm{O}\right.$, $\left.{ }^{17} \mathrm{O},{ }^{18} \mathrm{O}\right)$.

\section{Stable Isotope Notation and Units}

Stable-isotope results from RSIL are reported as isotopic compositions: $\delta^{2} \mathrm{H}$ and $\delta^{18} \mathrm{O}$ of water, and $\delta^{15} \mathrm{~N}$ and $\delta^{18} \mathrm{O}$ of dissolved nitrate $\left(\mathrm{NO}_{3}\right)$. Because ${ }^{2} \mathrm{H}$ is also called deuterium, $\delta^{2} \mathrm{H}$ also is referred to as $\delta \mathrm{D}$. The $\delta$ symbol signifies "delta notation," and isotopic compositions are pronounced "delta-H-2," "delta-N-15," and "delta-O-18." A sample's isotopic composition indicates the ratio of a heavier isotope to a lighter isotope in the sample relative to the same ratio in a reference standard (Kendall and Caldwell, 1998). The isotopic composition is represented by equation 3 .

$$
\delta_{\text {sample }}=\left[\left(\mathrm{R}_{\text {sample }} / \mathrm{R}_{\text {standard }}\right)-1\right] \times 1,000
$$

where

$$
\begin{gathered}
\delta_{\text {sample }}=\begin{array}{c}
\text { the sample isotopic composition }\left(\delta^{2} \mathrm{H},\right. \\
\\
\left.\delta^{15} \mathrm{~N}, \delta^{18} \mathrm{O}\right), \text { in parts per thousand } \\
(\text { or per mil [\%] }] \text {; }
\end{array} \\
\mathrm{R}_{\text {sample }=}{ }^{2} \mathrm{H} /{ }^{1} \mathrm{H},{ }^{15} \mathrm{~N} /{ }^{14} \mathrm{~N} \text {, or }{ }^{18} \mathrm{O} /{ }^{16} \mathrm{O} \text { in the } \\
\text { sample; and } \\
\mathrm{R}_{\text {standard }}=\begin{array}{c}
{ }^{2} \mathrm{H} /{ }^{1} \mathrm{H},{ }^{15} \mathrm{~N} /{ }^{14} \mathrm{~N} \text {, or }{ }^{18} \mathrm{O} /{ }^{16} \mathrm{O} \text { in the } \\
\text { reference standard. }
\end{array}
\end{gathered}
$$

Reference standards are Vienna Standard Mean Ocean Water (VSMOW) for $\mathrm{H}$ and $\mathrm{O}$ and atmospheric nitrogen gas for N. Isotopic compositions can be positive or negative: larger or more positive values are referred to as "heavier," and smaller or more negative values as "lighter." Positive and negative values arise from a sample being isotopically heavier or lighter (respectively) than the reference standard to which it is being compared.

Despite their complicated notation $(\delta)$, units (\%o), and values (negative and positive), isotopic compositions are straightforward to evaluate in source-tracking investigations. Isotopic compositions can mix conservatively (Kendall and Caldwell, 1998), such that the isotopic composition of water that is a mixture of two source waters will be between the isotopic compositions of the two sources waters, in the absence of isotopic-fractionation processes. 


\section{Hydrogen and Oxygen Isotopes in Water}

Isotopes of $\mathrm{H}$ and $\mathrm{O}$ that form water molecules are ideal tracers of water sources and water movement (Kendall and Caldwell, 1998). A given source water can have distinctive $\delta^{2} \mathrm{H}$ and $\delta^{18} \mathrm{O}$ values that investigators can use to identify the presence of that source water at different locations in a watershed. For example, $\delta^{2} \mathrm{H}$ and $\delta^{18} \mathrm{O}$ values in precipitation have been found to generally decrease with increasing elevation on Maui (Scholl and others, 2002) and on Hawai'i Island (Scholl and others, 1996; Tillman and others, 2014b; Fackrell, 2016). At Kīhei, Maui, $\delta^{2} \mathrm{H}$ and $\delta^{18} \mathrm{O}$ values of ambient groundwater were determined to be substantially different from those of tap water, which is transported from another part of the island (Hunt, 2007). Also, the $\delta^{2} \mathrm{H}$ and $\delta^{18} \mathrm{O}$ values of storm rainfall might be lower than those of trade-winds-generated rainfall, as explained in Scholl and others (1996).

For context, figure 11 shows the $\delta^{2} \mathrm{H}$ and $\delta^{18} \mathrm{O}$ compositions of water samples collected at different groups of sites in Hawai' $i$ between 2000 and 2017. The results shown in figure 11, which are limited to those stored in NWIS (USGS, 2016) as of June 2019, include results for samples collected for projects and efforts that are not shown in table 1. Each result was assigned to one of the following ten site groups, which were defined on the basis of site-type designations and sample medium-code designations that were obtained with the results from NWIS (USGS, 2016):

- the precipitation site group consists of all results that have an atmospheric-site-type designation
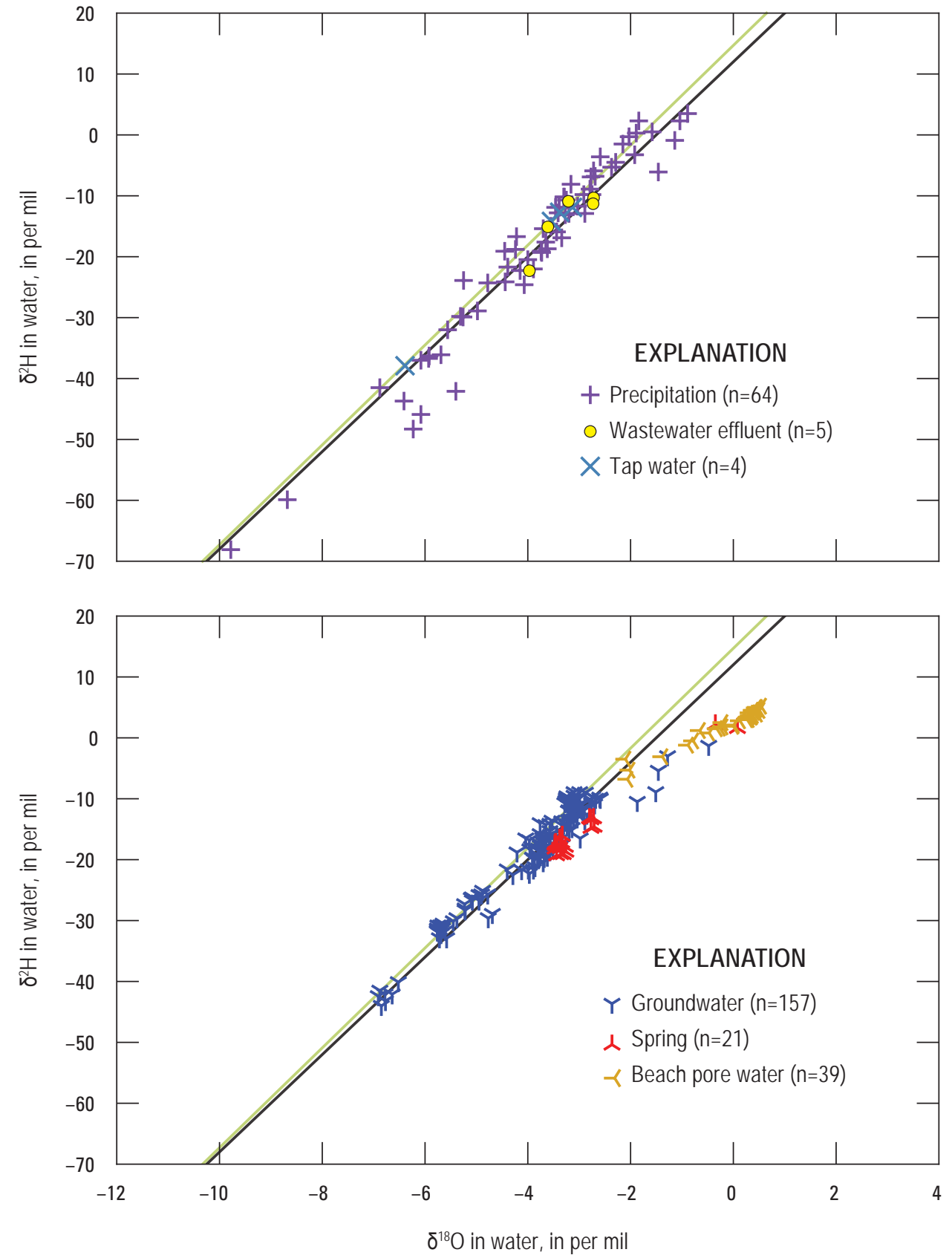

EXPLANATION

— Maui MWL

— Hawai'i Island MWL

Figure 11 (pages 32-33). Plots of $\delta^{2} \mathrm{H}$ versus $\delta^{18} \mathrm{O}$ compositions of water samples collected at different groups of sites on Kaua'i, O'ahu, Maui, and Hawai'i Island during 2000-17, relative to meteoric-water lines determined for Hawai'i Island and Maui (from Scholl and others, 1996, 2002). Number of samples (n) shown in parentheses (all data available from U.S. Geological Survey National Water Information System [USGS, 2016]). Isotopes: $H$, hydrogen; O, oxygen. 
- the wastewater-effluent site group consists of all results for those whose medium designation is effluent

- the tap-water site group consists of all results for those whose medium designation is treated water supply

- the beach-pore-water site group consists of all results for those whose medium designation is groundwater and were collected at sites that have a coastal-oceansite-type designation

- the remaining results were distributed into six site groups (coastal ocean; estuary; groundwater; lake; spring; or stream, ditch, or canal) on the basis of their site-type designations, which corresponded straightforwardly with the names of the six site groups.
As figure 11 shows, many samples have negative $\delta^{2} \mathrm{H}$ and negative $\delta^{18} \mathrm{O}$ values. The negative $\delta^{2} \mathrm{H}$ and $\delta^{18} \mathrm{O}$ values mean that the samples contain a smaller proportion of the heavier isotopes $\left({ }^{2} \mathrm{H},{ }^{18} \mathrm{O}\right)$ than VSMOW. Also included in figure 11 for additional context are two local meteoric-water lines (MWLs), each of which represents the relation between $\delta^{2} \mathrm{H}$ and $\delta^{18} \mathrm{O}$ in precipitation in a region. The Hawai' $\mathrm{i}$ Island MWL $\left(\delta^{2} \mathrm{H}=8 \times \delta^{18} \mathrm{O}+12\right)$ was determined for the southeastern part of Hawai'i Island by Scholl and others (1996); the Maui MWL $\left(\delta^{2} \mathrm{H}=8.2 \times \delta^{18} \mathrm{O}+14.7\right)$ was determined for the eastern part of Maui by Scholl and others (2002). The isotopic compositions of samples that plot on or near the appropriate MWL likely reflect those of precipitation that formed from condensation of cloud vapor. This appears to be the case for most of the groundwater, stream, ditch, and canal samples
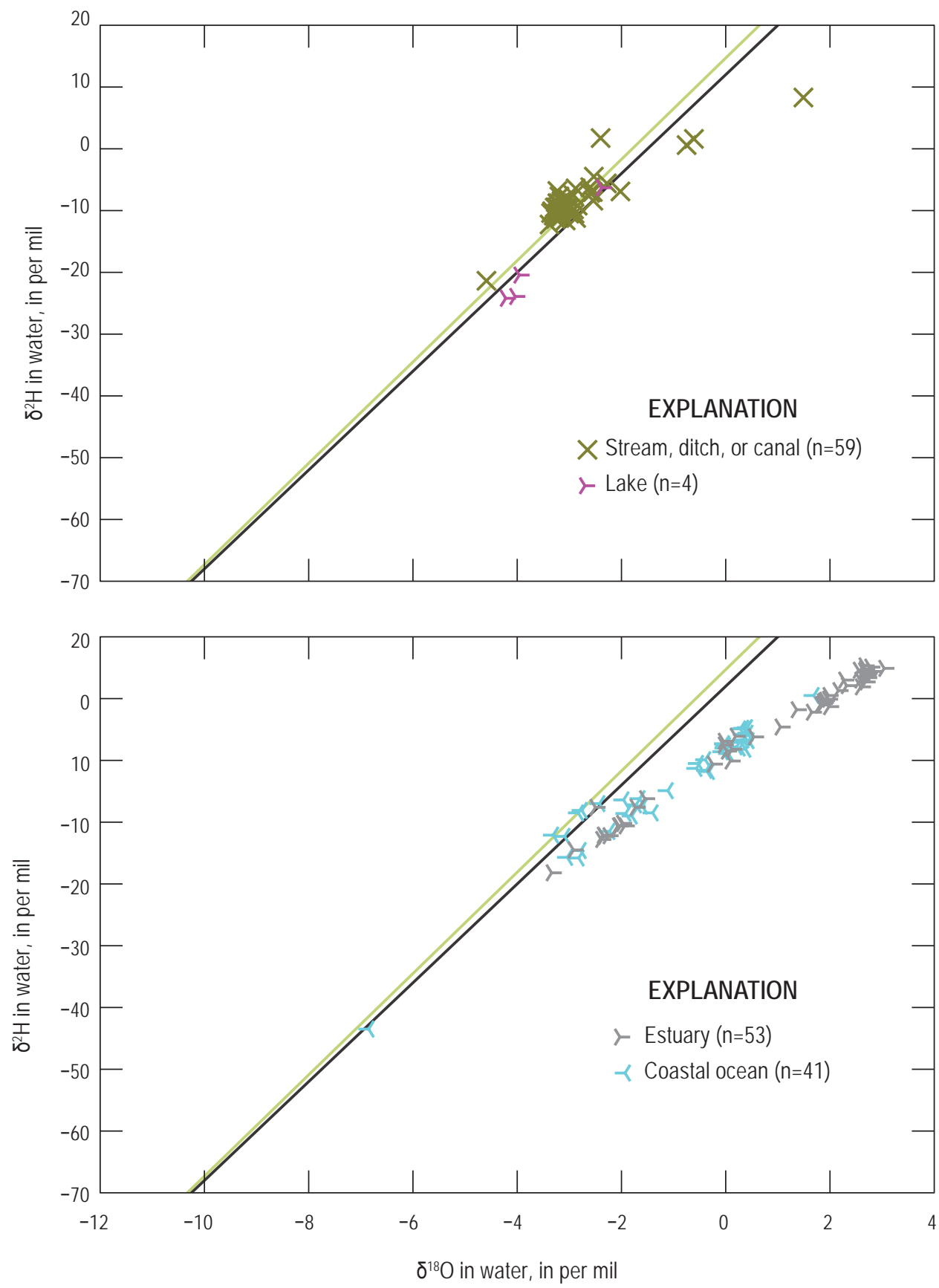

\section{EXPLANATION}

Maui MWL

Hawai'i Island MWL

\section{4}




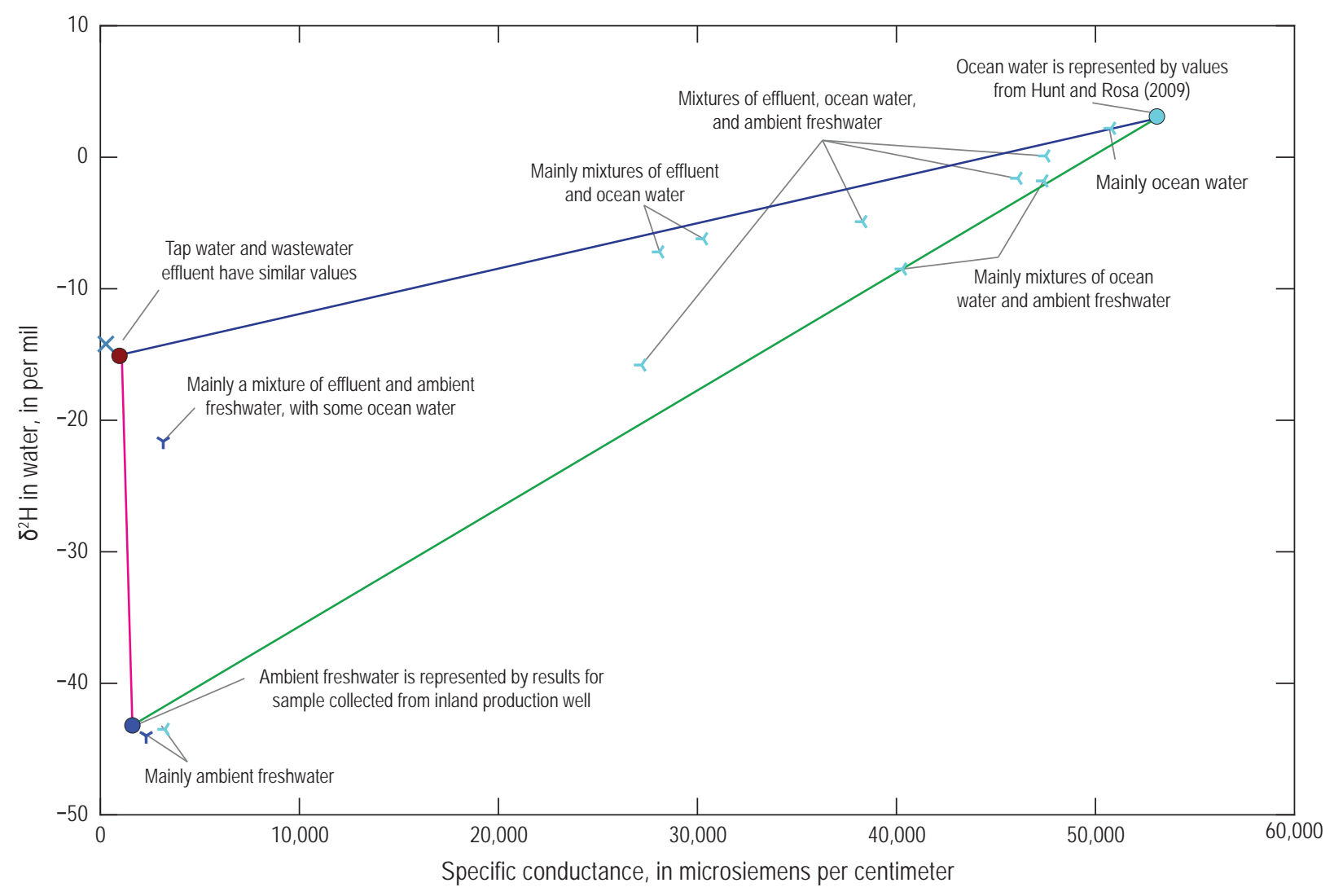

\begin{tabular}{lll}
\multicolumn{1}{c}{ Other water samples } & \multicolumn{2}{c}{ EXPLANATION } \\
$\times$ Tap water & Selected source waters & Mixing lines \\
Y Groundwater & - Ambient freshwater & Between wastewater effluent and ocean water \\
$\succ$ Coastal ocean & $\bigcirc$ Ocean water & Between ambient freshwater and ocean water
\end{tabular}

Figure 12. Plot of $\delta^{2} \mathrm{H}$ in water versus specific conductance for water samples collected near Kīhei, Maui, in 2004 and 2008. Unless otherwise noted, data are from U.S. Geological Survey National Water Information System (USGS, 2016). Annotations indicate how relations between positions of mixing lines and sample results can be used to interpret origins of water in samples. Isotope: $\mathrm{H}$, hydrogen.

that generally plot along or near the MWLs in figure 11. In contrast, most of the beach-pore-water, estuary, and coastalocean samples plot below and to the right of the MWLs. The deviation from the MWLs for each these samples is likely due to factors that include mixing with ocean water, evaporation, or both. For the 10 coastal-ocean samples shown in figure 11 that were determined to be at least 95 percent ocean water (that is, measured SC exceeded 50,433 microsiemens per centimeter), the median $\delta^{2} \mathrm{H}$ and $\delta^{18} \mathrm{O}$ values were 3.10 and 0.32 per mil, respectively. These median values could potentially be used to guide characterization of ocean water in mixing plots created by investigators who evaluate $\delta^{2} \mathrm{H}$ and $\delta^{18} \mathrm{O}$ results for samples collected during future source-tracking efforts.

The $\delta^{2} \mathrm{H}$ and $\delta^{18} \mathrm{O}$ isotopic compositions of water are changed only by mixing and by fractionation processes that occur during phase changes, such as evaporation, condensation, sublimation, and melt (McGuire and McDonnell, 2007). In other words, once precipitation infiltrates the subsurface and is away from evaporation, $\delta^{2} \mathrm{H}$ and $\delta^{18} \mathrm{O}$ compositions tend to remain fixed and behave conservatively (that is, not changing, other than by mixing with other water sources) during groundwater transport to destinations farther along the flow system. Therefore, in the absence of evaporation and other phase changes, the isotopic composition of a water sample that is a mixture of two source waters will fall on a straight line drawn between the isotopic compositions of the two source waters on a mixing plot (McGuire and McDonnell, 2007).

If the source waters in a watershed have contrasting $\delta^{2} \mathrm{H}$ and $\delta^{18} \mathrm{O}$ isotopic compositions, then investigators can attempt to use mixing plots to infer the presence of those source waters 
in the water samples. Figure 12 shows one mixing plot with water $\delta^{2} \mathrm{H}$ and SC results for samples collected in Kinhei, Maui, in 2004 and 2008, as part of the source-tracking efforts described in Hunt (2007) and Hunt and Rosa (2009). In the mixing plot, straight lines are drawn between the results for each pair of the three source waters, which at Kinhei consisted of wastewater effluent, groundwater pumped from an upland well (ambient freshwater), and ocean water. Each straight line represents a hypothetical mixing line between a pair of source waters. Samples that plot on or near a mixing line can be interpreted as likely being a mixture of those two source waters. Samples that plot in the area between all mixing lines can be interpreted as being a mixture of all three source waters, assuming no other source waters are present.

The same mixing-interpretation process can be repeated by creating a binary plot of $\delta^{18} \mathrm{O}$ relative to SC (not shown in fig. 12), although interpretations made from a binary plot of $\delta^{18} \mathrm{O}$ relative to $\mathrm{SC}$ are likely to be similar to those made from a $\delta^{2} \mathrm{H}-\mathrm{SC}$ plot, given the covariance of $\delta^{2} \mathrm{H}$ and $\delta^{18} \mathrm{O}$ in water (fig. 11). If the samples contain little to no ocean water, then a binary plot of $\delta^{2} \mathrm{H}$ relative to $\delta^{18} \mathrm{O}$ (not shown in fig. 12) might be more useful than plots of $\delta^{2} \mathrm{H}$ versus $\mathrm{SC}$ and $\delta^{18} \mathrm{O}$ versus SC. Investigators could place tentative mixing interpretations on a map showing the sampling sites to ensure their final mixing interpretations make sense geographically and are consistent with the general directions of groundwater flow and surface-water flow in the study area.

If septic systems, cesspools, or leaky sewer lines are suspected sources of wastewater in the environment, then tap water provided to the community can represent wastewater in mixing plots of $\delta^{2} \mathrm{H}$ and $\delta^{18} \mathrm{O}$ values. Investigators may not need to sample household wastewater because they can assume that the isotopic composition of community tap water remains unchanged as it (1) flows into households, (2) is used, (3) exits the household as wastewater, and (4) eventually seeps into groundwater. At Kīhei, tap water and treated effluent have nearly identical water $\delta^{2} \mathrm{H}$ (fig. 12) and $\delta^{18} \mathrm{O}$ values, which indicates that the isotopic signature of tap water is little modified through use and treatment processes and persists in wastewater.

If the water $\delta^{2} \mathrm{H}$ and $\delta^{18} \mathrm{O}$ values of wastewater or tap water are not considerably different from those of ambient freshwater in a study area, then $\delta^{2} \mathrm{H}$ and $\delta^{18} \mathrm{O}$ values of water may not help investigators infer the presence or absence of wastewater in the water samples. Hunt and Rosa (2009) determined that this was the case in Lahaina, Maui, where the isotopic compositions of wastewater effluent $\left(\delta^{2} \mathrm{H}=-10.90\right.$ per mil and $\delta^{18} \mathrm{O}=-3.21$ per mil) and ambient freshwater $\left(\delta^{2} \mathrm{H}=-14.00\right.$ per mil and $\delta^{18} \mathrm{O}=-3.76$ per mil) were similar.

As investigators develop conclusions from their waterisotope results, they generally would consider whether water in the study area might be substantially affected by any water phase changes, which can alter water-isotopic compositions. For example, evaporation could alter the isotopic composition of stagnant water in a shallow ditch that has minimal flow. Because evaporation preferentially removes water molecules that have lighter $\mathrm{H}$ and $\mathrm{O}$ isotopes, the $\delta^{2} \mathrm{H}$ and $\delta^{18} \mathrm{O}$ values of the remaining water in the ditch would increase after evaporation, assuming that the rate of water input to the ditch is small compared with the evaporation rate.

The mixing-interpretation approach described in this section has limitations. First, in order for the approach to be useful for source-tracking efforts, wastewater in a study area must have $\delta^{2} \mathrm{H}$ and $\delta^{18} \mathrm{O}$ values that contrast with those of other source waters. Second, the isotopic compositions of the source waters are assumed to be temporally constant. Third, the assumption of only 2 to 3 source waters in a study area might be an oversimplification. For example, the description of the Kinhei example in this section did not mention other possible source waters, including recharge from precipitation over the wastewater-plume area between the upgradient well (ambient freshwater) sampling location and the coastline. Hunt and Rosa (2009), however, sampled a cross-gradient well located outside but near the edge of the wastewater plume, and water $\delta^{2} \mathrm{H}$ and $\delta^{18} \mathrm{O}$ compositions from the cross-gradient well were nearly identical to those in the upgradient well, indicating a minimal change to $\delta^{2} \mathrm{H}$ and $\delta^{18} \mathrm{O}$ compositions of ambient freshwater in the area between the upgradient well and cross-gradient well.

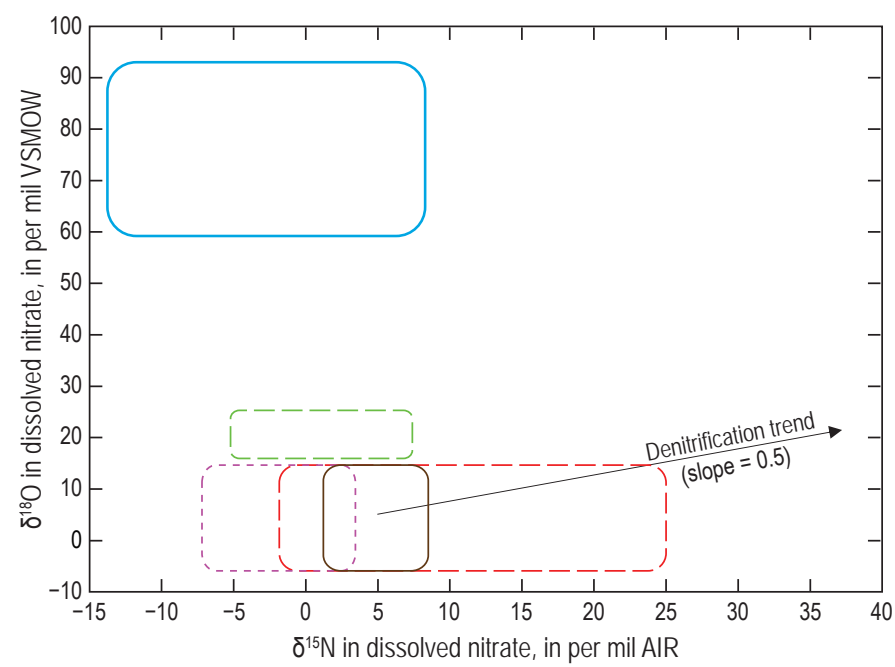

EXPLANATION

$\begin{array}{ll}\square \text { Nitrate in precipitation } & \square \text { Manure and septic waste } \\ \square \text { Nitrate fertilizer } & \end{array}$

Figure 13. Graph showing nitrate source classification that is based on nitrogen and oxygen stable-isotope compositions of dissolved nitrate. Modified from graph provided by Carol Kendall (U.S. Geological Survey, written commun., 2006), which was modified from Kendall (1998). Although useful as general guide, isotopic compositions can be shifted by fractionation processes, such as denitrification. Isotopes: $\mathrm{N}$, nitrogen; $\mathrm{O}$, oxygen. Other abbreviations: AIR, atmospheric air; $\mathrm{NH}_{4}$, ammonium ion; VSMOW, Vienna Standard Mean Ocean Water. 


\section{Nitrogen and Oxygen Isotopes in Dissolved Nitrate}

Under favorable circumstances, isotopic compositions of nitrate $\delta^{15} \mathrm{~N}$ and $\delta^{18} \mathrm{O}$, in combination with nitrate concentrations, can provide insight into the dominant source of nitrate in waters. Various sources of nitrate have been found to have distinctive ranges of $\delta^{15} \mathrm{~N}$ and $\delta^{18} \mathrm{O}$ values (fig. 13). For example, $\delta^{18} \mathrm{O}$ typically is greater in nitrate fertilizers and in nitrate from precipitation than in nitrate derived from manure and septic waste (fig. 13). A $\delta^{15} \mathrm{~N}$ value can be greater in nitrate derived from animal manure and wastewater than in nitrate derived from ammonium fertilizers and nitrate from soil organic matter, although the general ranges of $\delta^{15} \mathrm{~N}$ values for these three nitrate sources partially overlap.

To begin an evaluation of nitrate-isotope results, investigators can create a plot of a sample's nitrate $\delta^{18} \mathrm{O}$ and $\delta^{15} \mathrm{~N}$ results and then compare the sample results to the typical isotopic-composition ranges for the different nitrate sources shown on figure 13. For example, a sample that has nitrate $\delta^{15} \mathrm{~N}$ values on the order of about +10 per mil or greater would imply that the nitrate is originating from manure, septic waste, or both. Inferences of nitrate sources made by such comparisons, however, may be accurate only if (1) the sample's nitrate predominantly originates from one nitrate source and not two or more sources, and (2) the nitrate of the implied source has not been substantially affected by any isotope-fractionation processes that consume nitrate, such as denitrification or biological uptake (assimilation).

Denitrification is a process that converts nitrate to a succession of nitrogen oxides and ultimately to nitrogen gas. It is facilitated by anaerobic bacteria and occurs when oxygen is limited and organic carbon is available (Knowles, 1982). For example, denitrification, can occur in coastal sediments and estuaries that have large amounts of organic matter (Libes, 1992).

Denitrification causes $\delta^{15} \mathrm{~N}$ and $\delta^{18} \mathrm{O}$ values of the residual nitrate to increase and residual nitrate concentrations to decrease (Kendall and others, 2007). In other words, denitrification of nitrate from soils could result in nitrate $\delta^{15} \mathrm{~N}$ values that plot outside and to the right of the general range of soil nitrate $\delta^{15} \mathrm{~N}$ values shown in figure 13. Because denitrification alters (increases) $\delta^{15} \mathrm{~N}$ and $\delta^{18} \mathrm{O}$ compositions of the residual nitrate, investigators likely will want to assess whether denitrification is occurring in the study area.

Several methods can be used to infer denitrification in the environment. One method involves examining sample results on a plot of nitrate $\delta^{18} \mathrm{O}$ versus nitrate $\delta^{15} \mathrm{~N}$. Denitrification can be inferred if samples plot along a line that has a slope (nitrate $\delta^{18} \mathrm{O} /$ nitrate $\delta^{15} \mathrm{~N}$ ) of 0.5 (according to Kendall, 1998) or between about 0.48 and 0.77 (according to Xue and others, 2009).

Denitrification might also be inferred and distinguished from the mixing of two nitrate sources on the basis of spatial differences in sample results for nitrate $\delta^{15} \mathrm{~N}$ and nitrate concentrations. Specifically, investigators could examine how nitrate $\delta^{15} \mathrm{~N}$ and nitrate concentration values change with respect to the general direction of groundwater and surfacewater flow in the study area. In a typical Hawaiian watershed, the general direction of water flow typically is from inland mountains toward streams and the coastline. If all samples are predominantly freshwater, then increases in $\delta^{15} \mathrm{~N}$ values, combined with decreases in nitrate concentrations, in the general direction of water flow would be consistent with denitrification. In contrast, increases in both $\delta^{15} \mathrm{~N}$ values and nitrate concentrations in the general direction of water flow would be consistent with additions of nitrate from animal and septic waste to ambient freshwater. For example, a site that has $\delta^{15} \mathrm{~N}$ values and nitrate concentrations exceeding those of ambient freshwater might contain a mixture of nitrate from ambient freshwater and nitrate derived from animal or septic waste; this inference may be true even if the $\delta^{15} \mathrm{~N}$ value is less than +10 per mil. If $\mathrm{SC}$ measurements indicate that some samples are a mixture of freshwater and ocean water, then the same assessment approach can be used with nitrate enrichment values instead of nitrate concentrations (see section above entitled, "Nutrients," for a description as to how to compute nitrate enrichment values). For example, increases in $\delta^{15} \mathrm{~N}$ values, combined with decreases in nitrate enrichment values, in the general direction of water flow would be consistent with denitrification. In contrast, increases in both $\delta^{15} \mathrm{~N}$ values and nitrate enrichment values in the general direction of water flow would be consistent with additions of nitrate from animal and (or) septic waste to ambient freshwater.

If sampled waters are predominantly fresh, then the distinction between denitrification and mixing might be inferred from two additional binary plots, (1) nitrate $\delta^{15} \mathrm{~N}$ values relative to the inverse of nitrate concentrations, and (2) $\delta^{15} \mathrm{~N}$ relative to the natural logarithm of nitrate concentration (see, for example, Burns and others, 2009). Plot 1 will yield a straight line for mixtures of two nitrate sources (for example, ambient freshwater and septic waste), whereas plot 2 will yield a straight line for denitrification and other process that can be expressed using the Rayleigh equation (Kendall, 1998). If both plots yield straight lines, then both mixing and denitrification may have occurred (see, for example, Burns and others, 2009).

Field observations also may provide evidence of denitrification. For example, dissolved-oxygen values that are much lower than values for ocean water or a well-mixed stream would indicate the possibility of anaerobic conditions, which usually are needed for denitrification. Hunt (2014) inferred the occurrence of denitrifying conditions in an aquifer at Kaloko-Honokōhau on the basis of the detected scent of hydrogen sulfide gas at one of the groundwater-sampling sites. Hydrogen sulfide is produced during sulfate reduction, which is an intermediate step in a sequence of microbially mediated redox reactions, and it typically is preceded by denitrification (Libes, 1992).

A different type of field observation was used to infer the presence of denitrification in groundwater near Kahalu' $u$, O'ahu, where the lower reaches of two streams ('Āhuimanu Stream, Kahalu 'u Stream) had concrete channel beds and 
walls. During the Kahalu'u Stream sampling efforts, which were conducted in 2017 during fair-weather conditions, field personnel observed rust-colored particulates at points where groundwater appeared to be flowing into the stream channel through seams in the concrete floor and through drainage holes constructed in the concrete walls. The presence of the rust-colored particulates at these points was considered evidence of oxygen-poor groundwater, which is favorable for denitrification and also allows iron from rocks and soils to dissolve more readily into water. When oxygen-poor groundwater is exposed to the atmosphere, its dissolved reduced iron reacts with oxygen in the atmosphere and can form rust-colored iron-oxide precipitates.

Assimilation is the conversion of inorganic nitrogenbearing compounds into organic compounds during biosynthesis by living organisms (Kendall and others, 2007). Nitrate assimilation, like denitrification, results in increases in $\delta^{15} \mathrm{~N}$ values combined with decreases in nitrate-enrichment values in the general direction of water movement. On a binary plot of nitrate $\delta^{18} \mathrm{O}$ relative to nitrate $\delta^{15} \mathrm{~N}$, sample results that plot along a line that has a slope of 1 would be consistent with nitrate assimilation by marine phytoplankton (Granger and others, 2004). Hence, the assimilation slope value of 1 is greater than the range of denitrification slope values $(0.48-0.77)$ described previously in this report.

The use of nitrate $\delta^{18} \mathrm{O}$ and nitrate $\delta^{15} \mathrm{~N}$ for sourcetracking efforts has limitations. Nitrate $\delta^{18} \mathrm{O}$ and nitrate $\delta^{15} \mathrm{~N}$ usually cannot be used to distinguish between nitrate derived from manure and nitrate from septic waste because these two nitrate sources have overlapping isotopic compositions (Kendall and others, 2007) (fig. 13). If background information indicates that animal manure and septic waste might be two substantial nitrate sources in a study area, then results of the pharmaceutical compounds and organic-waste compounds might be a more definitive indicator of wastewater presence or absence than nitrate isotopes.

\section{Organic-Waste Compounds and Human-Use Pharmaceutical Compounds}

The organic-waste compounds currently analyzed by NWQL (schedule 4433) include disinfectants, antioxidants, detergent metabolites, fire retardants, flavors (food additives), fragrances, fuel components, pesticides, nonprescription drugs, plasticizers, polycyclic aromatic hydrocarbons, solvents, and sterols (table 4). NWQL refers to the organicwaste compounds as "wastewater compounds" because they are commonly found in domestic and industrial wastewater

\footnotetext{
${ }^{2}$ Remarks and value qualifiers are separate attributes included with results obtained from NWIS: remarks are symbols or letters that represent explanations that qualify a result (see https:/help.waterdata.usgs.gov/code/ remark_cd_query? $\mathrm{fmt}=\mathrm{html}$ ); value qualifiers are symbols or letters that represent additional information about a result and aid in its interpretation (see https://help.waterdata.usgs.gov/code/val_qual_cd_query?fmt=html).
}

(Zaugg and others, 2007a). Some of the organic-waste compounds, however, may originate from agricultural, industrial, or natural sources within a watershed (table 4). Table 5 lists the human-use pharmaceutical compounds that are currently analyzed in filtered water at NWQL using schedule 2440.

Detections of several pharmaceutical compounds and several selected organic-waste compounds at a site indicate the likelihood of wastewater presence. Therefore, for the source-tracking approach, investigators would evaluate results for each of the organic-waste compounds and pharmaceutical compounds in terms of being a detection or nondetection in each sample. Scientists who assess the potential hazards of these compounds to the health of humans and aquatic life often compare the concentrations of compounds in water to various water-quality criteria, but this effort is not required for the source-tracking approach.

Users of the source-tracking approach may consider establishing their own definitions of "detection" and "nondetection" for their study. Prior to establishing these definitions, investigators will typically evaluate how results are reported by their laboratory and then execute several data-preparation steps. The manner in which NWQL reports results for the water samples it analyzes for organic-waste and pharmaceutical compounds is described below; however, reporting conventions for samples analyzed prior to 2015 may be different (see Williams and others, 2015).

Result values for organic-waste compounds and pharmaceutical compounds are reported by the NWQL as concentrations: organic-waste compounds are reported in units of micrograms per liter $(\mu \mathrm{g} / \mathrm{L})$, approximately equal to parts per billion; pharmaceutical compounds are reported in units of nanograms per liter (ng/L), approximately equal to parts per trillion. Each result value can have an associated remark and several value qualifiers, ${ }^{2}$ all of which can be obtained by those who retrieve sample results from NWIS (USGS, 2016).

For each compound and analytical method, NWQL establishes two concentration markers, a reporting level and a detection level, which are determined using statistical methods (Williams and others, 2015) and are established to minimize false-positive and false-negative errors (Childress and others, 1999). A false-positive error occurs when a compound is identified as being present but is actually absent, whereas a false-negative error occurs when a compound is present but is not identified as being present. Tables 4 and 5 show NWQL's reporting and detection levels as of June 2019 for each organic-waste and pharmaceutical compound. Each compound's reporting level is greater than its detection level, by a factor of 2 for the organic-waste compounds and by factor of about 2 to 12 for the pharmaceutical compounds. A compound's reporting and detection levels may change over time, as they are computed values and not instrument thresholds, meaning that NWQL can identify compounds that are present at concentrations that are below their reporting and detection levels. 
Each compound that is identified by NWQL as being absent from a water sample has a "less than" sign $(<)$ as a remark and the compound's reporting level as the result value. For example, if the pharmaceutical acetaminophen is determined to be absent from a water sample, its result will be reported as $<20 \mathrm{ng} / \mathrm{L}$, and investigators can conclude that the chance of a false negative (that is, acetaminophen is actually present at $20 \mathrm{ng} / \mathrm{L}$ but was not identified) is no greater than 1 percent.

Each compound that is identified by NWQL as being present in a water sample does not have the "less than" sign $(<)$ as a remark and has the concentration of the compound as the result value. Compounds identified as being present in a water sample can fall within three concentration ranges, (1) at or above a compound's reporting level, (2) below the compound's reporting level but at or above a compound's detection level, or (3) below a compound's detection level. The uncertainties of results within each of these three ranges are not the same. In terms of a compound being present or absent, results that are reported at or above a compound's reporting level have the least uncertainty. Results that are reported below a compound's detection level have the greatest uncertainty and generally are viewed with caution because the risk of a false positive is greater than 1 percent. Results that are reported below a compound's reporting level but at or above the detection level have intermediate uncertainty. At the detection level, the risk of a false positive is no more than 1 percent.

Investigators typically would conduct several datapreparation steps to define which of their results are detections and which of their results are nondetections. The sourcetracking approach proposes five data-preparation steps (A through E) that are similar to those used by Bexfield and others (2019), who evaluated the occurrence of hormones and pharmaceuticals in drinking-water aquifers throughout the United States but not in Hawai' $i$. Bexfield and others (2019) indicated that their data-preparation steps maximized confidence that all results defined as detections in their analysis resulted from the occurrence of hormones or pharmaceuticals in groundwater and not from field or laboratory contamination. The following five data-preparation steps for source-tracking efforts involve defining and selecting detections by evaluating the remarks and value qualifiers included with each sample result:

Step A.-All results that are reported by NWQL as being absent from water samples are considered nondetections and have a "<" remark. All remaining results reported by NWQL as being present in water samples can be considered as potential detections for step B.

Step B.-Investigators decide which concentration ranges will be treated as detections. For example, to establish a risk of false-positive detections as being no greater than 1 percent, Bexfield and others (2019) treated all results below detection levels as nondetections and then considered all results at concentrations at or above detection levels as potential detections to consider for subsequent data-preparation steps. Results that are obtained from NWIS (USGS, 2016) and that are reported below a compound's detection level will include a " $\mathrm{t}$ " value qualifier; results that are reported below a compound's reporting level but at or above the detection level will include an " $n$ " value qualifier. If detection levels (or reporting levels) changed during sample-collection efforts, then investigators may want to select one consistent set of detection levels (or reporting levels) to use for this step. Results that include an "E" remark, which means that the concentration of a compound was estimated by NWQL for a variety of possible reasons (Childress and others, 1999), might be considered as inconclusive detections if their concentration values are near the detection thresholds established in this step.

Step C.--Investigators use steps A and B to identify which compounds, if any, were detected in environmental samples and associated field blanks. In general, if the concentration of a compound detected in a field blank is similar to, or greater than, concentrations in associated environmental samples, then the compound's results in the environmental samples are not considered detections. In these instances, results obtained from NWIS (USGS, 2016) will include an uppercase "V" remark to indicate that the sample concentration values have been affected by contamination.

Step D.-Investigators identify which compounds, if any, were detected in environmental samples and associated laboratory blanks. Results obtained from NWIS (USGS, 2016) will include a lowercase " $v$ " value qualifier for each compound that is detected in any laboratory blanks associated with an environmental sample. In other words, a lowercase "v" value qualifier indicates that a compound was detected in a laboratory blank, whereas an uppercase "V" remark indicates that a compound was detected in a field blank. To reduce the risk of mistakenly concluding that wastewater is present at sampling sites, investigators could choose to consider all results that have a "v" value qualifier as nondetections. Alternatively, for this step, investigators can consider using the relatively comprehensive approach of censoring their results on the basis of laboratory blanks (this approach is described in Bexfield and others, 2019).

Step E.--Investigators attempt to identify any erroneous results and then consider the erroneous results as nondetections. For example, Bexfield and others (2019) treated all nicotine and cotinine results as nondetections because of evidence of widespread field contamination for these compounds.

After identifying which of their results are detections, investigators identify which compounds were detected at each site. Detection of several pharmaceutical compounds at a site indicates the likelihood of wastewater presence. It is worth noting that NWQL's analytical schedule of pharmaceutical compounds also includes the herbicide atrazine, for comparison with results determined by its other analytical schedules that test water for atrazine. Atrazine, however, is not an indicator of wastewater presence because atrazine may originate from herbicide applications in past or present agricultural areas.

Several organic-waste compounds may originate from natural sources or from sources other than wastewater (see table 4, "Possible sources or uses" column). For example, 13 


\section{EXPLANATION}

Compound was not analyzed in any groundwater or surface-water samples collected at general location during period shown

Compound was analyzed in at least one groundwater or surface-water sample collected at general location during period shown, but was not detected

Compound was analyzed and detected in at least one groundwater or surface-water sample collected at general location during period shown

\section{Organic-waste compound}

1,4-Dichlorobenzene

1-Methylnaphthalene

2,6-Dimethylnaphthalene

2-Methylnaphthalene

3,4-Dichlorophenyl isocyanate

3-beta-Coprostanol

3-Methyl-1H-indole

3-tert-Butyl-4-hydroxyanisole

4-Cumylphenol

4-n-Octylphenol

4-Nonylphenol (sum of all isomers)

4-Nonylphenol diethoxylate (sum of all isomers)

4-Nonylphenol monoethoxylate (sum of all isomers)

4-tert-Octylphenol

4-tert-Octylphenol diethoxylate

4-tert-Octylphenol monoethoxylate

5-Methyl-1H-benzotriazole

9,10-Anthraquinone

Acetophenone

Acetyl hexamethyl tetrahydro naphthalene

Anthracene

Atrazine

BDE congener 47

Benzo[a]pyrene

Benzophenone

beta-Sitosterol

beta-Stigmastanol

Bis(2-ethylhexyl) phthalate

Bisphenol A

Bromacil

Caffeine

Camphor

Carbaryl

Carbazole

Chlorpyrifos

Cholesterol

\section{Class}

Miscellaneous

Fuel

Fuel

Fuel

Herbicide

Sterols

Flavors and fragrance

Antioxidant

Detergent metabolite

Detergent metabolite

Detergent metabolite

Detergent metabolite

Detergent metabolite

Detergent metabolite

Detergent metabolite

Detergent metabolite

Antioxidant

Dye/pigment

Flavors and fragrance

Flavors and fragrance

$\mathrm{PAH}$

Herbicide

Fire retardant

$\mathrm{PAH}$

Flavors and fragrance

Sterols

Sterols

Plasticizer

Antioxidant

Herbicide

Nonprescription drug

Flavors and fragrance

Insecticide

Insecticide

Insecticide

Sterols

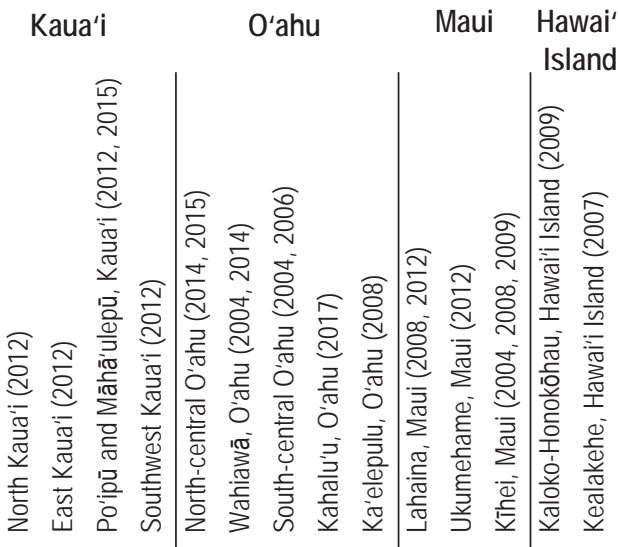

00000000000000 00000000000000 00000000000000 00000000000000 00000000000000 00000000000000 00000000000000 00000000000000 00000000000000 00000000000000 00000000000000 - o o o o o o o o o o o 00000000000000 00000000000000 00000000000000 00000000000000 00000000000000 00000000000000 00000000000000 00000000000000 00000000000000 00000000000000 00000000000000 00000000000000 00000000000000 00000000000000 00000000000000 00000000000000 00000000000000 00000000000000

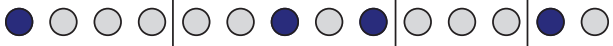
00000000000000 00000000000000 00000000000000 00000000000000 00000000000000

Figure 14 (pages 39-40). Occurrence of organic-waste compounds in groundwater and surface-water samples collected at 14 general locations in Hawai'i during 2004-17 (study year[s] shown in parentheses; see figures 16-18 for general locations of sites that had sampling results). Results considered were limited to those for samples that were analyzed for organic-waste compounds according to Zaugg and others (2007a, b) and that were available in U.S. Geological Survey National Water Information System (USGS, 2016) as of June 2019. Contents of "Class" column are modified from Baldwin and others (2016). Abbreviation: PAH, polycyclic aromatic hydrocarbon. 


\section{EXPLANATION}

Compound was not analyzed in any groundwater or surface-water samples collected at general location during period shown

Compound was analyzed in at least one groundwater or surface-water sample collected at general location during period shown, but was not detected

- Compound was analyzed and detected in at least one groundwater or surface-water sample collected at general location during period shown

\section{Organic-waste compound}

Cotinine

D-Limonene

Diazinon

Dichlorvos

Diethyl phthalate

Fluoranthene

Hexahydrohexamethyl cyclopentabenzopyran

Indole

Isoborneol

Isophorone

Isopropylbenzene

Isoquinoline

Menthol

Metalaxyl

Methyl salicylate

Metolachlor

$\mathrm{N}, \mathrm{N}$-Diethyl-m-toluamide (DEET)

Naphthalene

p-Cresol

Pentachlorophenol

Phenanthrene

Phenol

Prometon

Pyrene

Tetrachloroethene

Tribromomethane

Tributyl phosphate

Triclosan

Triethyl citrate

Triphenyl phosphate

Tris(2-butoxyethyl) phosphate

Tris(2-chloroethyl) phosphate

Tris(dichloroisopropyl) phosphate

\section{Class}

Nonprescription drug

Flavors and fragrance

Insecticide

Insecticide

Plasticizer

$\mathrm{PAH}$

Flavors and fragrance

Flavors and fragrance

Flavors and fragrance

Solvent

Fuel

Flavors and fragrance

Nonprescription drug

Fungicide

Miscellaneous

Herbicide

Insecticide

PAH

Antimicrobial disinfectant

Herbicide

$\mathrm{PAH}$

Antimicrobial disinfectant

Herbicide

$\mathrm{PAH}$

Solvent

Miscellaneous

Fire retardant

Antimicrobial disinfectant

Plasticizer

Plasticizer

Fire retardant

Plasticizer

Fire retardant

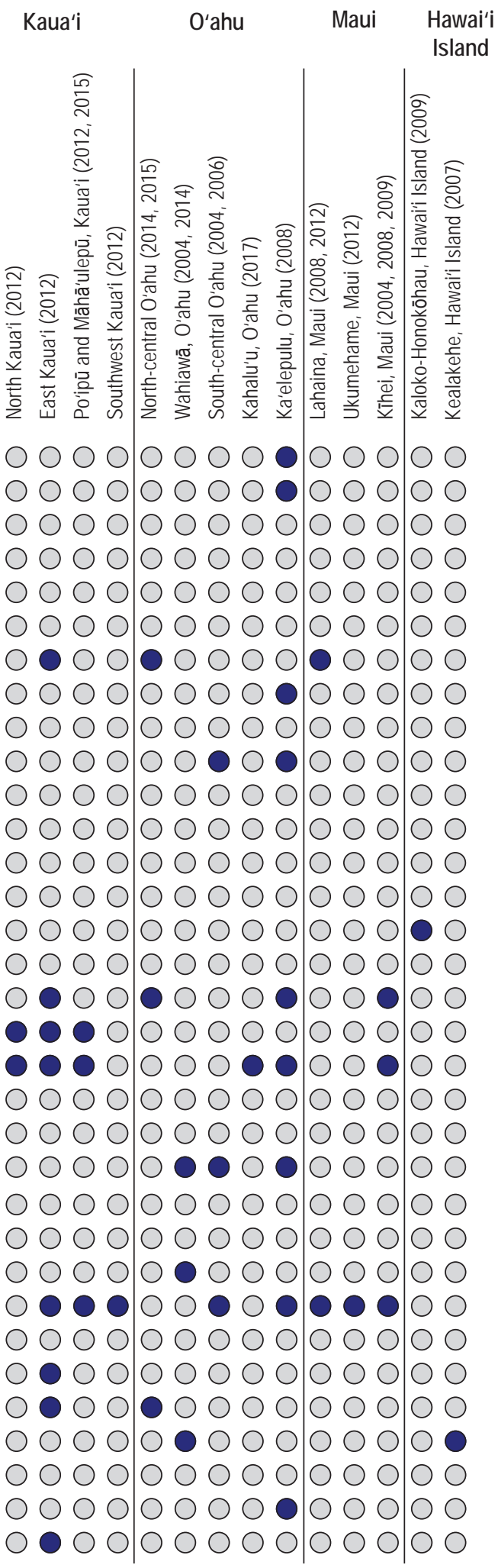

Figure 14 (pages 39-40). -Continued 


\section{EXPLANATION}

Compound was not analyzed in any groundwater or surface-water samples collected at general location during period shown

Compound was analyzed in at least one groundwater or surface-water sample collected at general location during period shown, but was not detected

Compound was analyzed and detected in at least one groundwater or surface-water sample collected at general location during period shown

\begin{tabular}{|c|c|}
\hline Pharmaceutical compound & Description and theraputic use \\
\hline 1,7-Dimethylxanthine & Metabolite of caffeine, a stimulant \\
\hline 10-Hydroxy-amitriptyline & Metabolite of amitriptyline, an antidepressant \\
\hline Abacavir & Antiviral, reverse transcriptase inhibitor \\
\hline Acetaminophen & Analgesic, antipyretic \\
\hline Acyclovir & Antiviral \\
\hline Albuterol & Bronchodilator, asthma treatment \\
\hline Alprazolam & Antianxiety \\
\hline Amitriptyline & Antidepressant \\
\hline Amphetamine & Central nervous system stimulant \\
\hline Antipyrine & Analgesic, antipyretic \\
\hline Atenolol & Antihypertensive, beta blocker \\
\hline Atrazine & Herbicide (not a pharmaceutical compound) \\
\hline Benztropine & Anticholinergic \\
\hline Betamethasone & Glucocorticoid, treatment of skin conditions \\
\hline Bupropion & Antidepressant and smoking-cessation aid \\
\hline Caffeine & Stimulant in coffee, tea, other beverages, and food \\
\hline Carbamazepine & Anticonvulsant, mood stabilizer \\
\hline Carisoprodol & Muscle relaxant \\
\hline Chlorpheniramine & Antihistamine for allergy relief \\
\hline Cimetidine & Decreases production of stomach acid \\
\hline Citalopram & Antidepressant, antianxiety \\
\hline Clonidine & Antihypertensive \\
\hline Codeine & Opiate analgesic, antitussive, antidiarrheal \\
\hline Cotinine & Metabolite of nicotine, a consituent in tobacco \\
\hline Dehydronifedipine & Metabolite of nifedipine, an antihypertensive \\
\hline Desmethyldiltiazem & Degradate of diltiazem \\
\hline Desvenlafaxine & Antidepressant and metabolite of venlafaxine \\
\hline Dextromethorphan & Antitussive \\
\hline Diazepam & Antianxiety, sleep aid, anticonvulsant, sedative \\
\hline Diltiazem & Antihypertensive, vasodilator \\
\hline Diphenhydramine & Antihistamine \\
\hline Duloxetine & Antidepressant \\
\hline Erythromycin & Macrolide antibiotic \\
\hline Ezetimibe & Cholesterol reduction \\
\hline Fadrozole & Aromatase inhibitor \\
\hline Famotidine & Stomach acid reducer \\
\hline
\end{tabular}

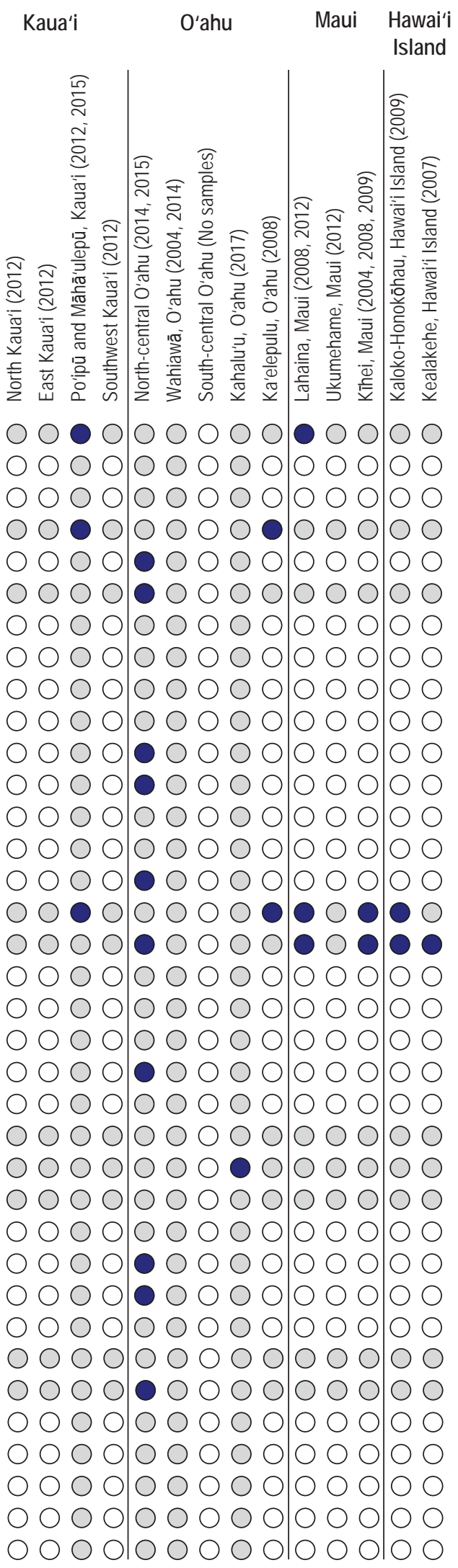

Figure 15 (pages 41-43). Occurrence of pharmaceutical compounds in groundwater and surface-water samples collected at 14 general locations in Hawai'i during 2007-17 (study year[s], if applicable, shown in parentheses; see figures 16-18 for general locations of sites that had sampling results). Results considered were limited to those for samples that were analyzed for pharmaceutical compounds according to Furlong and others $(2008,2014)$ and that were available in U.S. Geological Survey National Water Information System (USGS, 2016) as of June 2019. Contents of "Description and therapeutic use" column are modified from Furlong and others $(2014,2017)$ and Romanok and others $(2018)$. 


\section{EXPLANATION}

Compound was not analyzed in any groundwater or surface-water samples collected at general location during period shown

Compound was analyzed in at least one groundwater or surface-water sample collected at general location during period shown, but was not detected

Compound was analyzed and detected in at least one groundwater or surface-water sample collected at general location during period shown

Kaua'i O'ahu Maui $\begin{gathered}\text { Hawai'i } \mathrm{i} \\ \text { Island }\end{gathered}$

Pharmaceutical compound

Fenofibrate

Fexofenadine

Fluconazole

Fluoxetine

Fluticasone propionate

Fluvoxamine

Gabapentin

Glipizide

Glyburide

Guanylurea

Hexamethylenetetramine

Hydrocodone

Hydrocortisone

Hydroxyzine

Iminostilbene

Ketoconazole

Lamivudine

Lidocaine

Loperamide

Loratadine

Lorazepam

Meprobamate

Metaxalone

Metformin

Methadone

Methocarbamol

Methotrexate

Methyl-1H-benzotriazole

Metoprolol

Morphine

Nadolol

Nevirapine

Nicotine

Nizatidine

Nordiazepam

Norethindrone

Norfluoxetine

Norsertraline

\section{Description and theraputic use}

Cholesterol reducer

Degradate of terfenadine degradate

Antifungal

Antidepressant, antianxiety

Glucocorticoid, antiallergenic

Antidepressant, antianxiety

Anticonvulsant

Antidiabetic

Antidiabetic

Degradate of metformin, an antidiabetic

Treatment of urinary tract infection

Antitussive, opioid analgesic

Glucocorticoid, anti-inflammatory

Antihistamine, sedative

Anticonvulsant, antidepressant

Antifungal

Antiretroviral

Topical anesthetic

Antidiarrheal

Antihistamine

Anxiolytic, sedative, anticonvulsant

Anxiolytic, sedative

Muscle relaxant

Treatment of Type 2 diabetes

Opioid analgesic, antitussive

Muscle relaxant

Antimetabolite, treatment of cancer and psoriasis

Drug precursor, also a corrosion inhibitor

Antihypertensive, beta blocker

Opiate analgesic

Antihypertensive, beta blocker

Antiretroviral

Stimulant in tobacco

Acid inhibitor

Antianxiety, metabolite of diazepam

Oral contraceptive component

Metabolite of fluoxetine, an antidepressant

Degradate of sertraline, an antidepressant

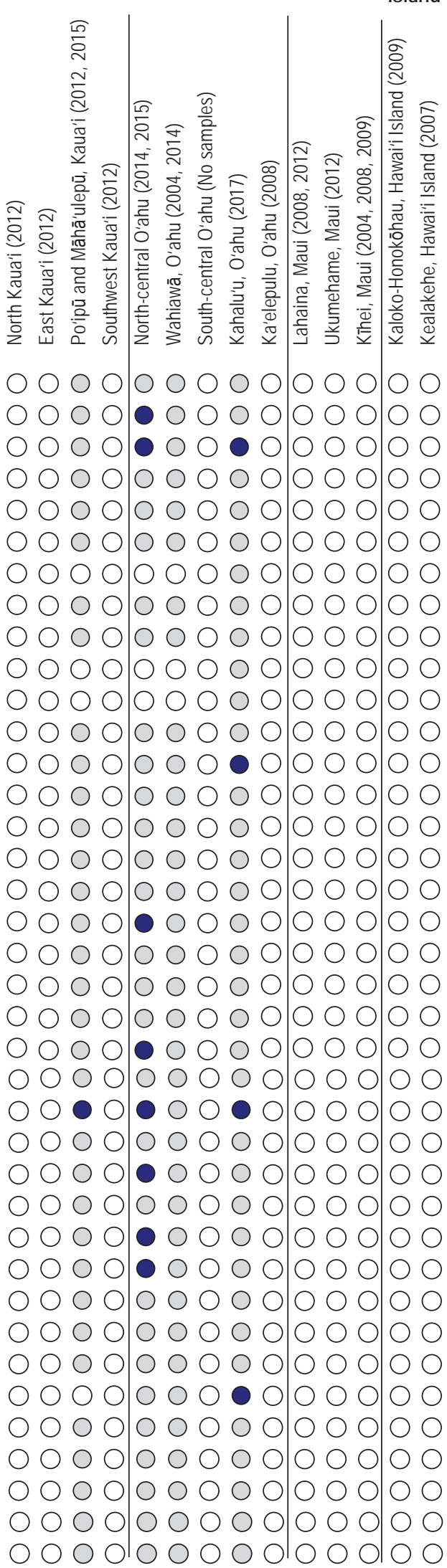

Figure 15 (pages 41-43). - Continued 


\section{EXPLANATION}

Compound was not analyzed in any groundwater or surface-water samples collected at general location during period shown

Compound was analyzed in at least one groundwater or surface-water sample collected at general location during period shown, but was not detected

Compound was analyzed and detected in at least one groundwater or surface-water sample collected at general location during period shown

\begin{tabular}{|c|c|}
\hline Pharmaceutical compound & Description and theraputic use \\
\hline Norverapamil & Metabolite of verapamil, an antihyperintensive \\
\hline Omeprazole + Esomeprazole & Treatment of dyspepsia and ulcers \\
\hline Oseltamivir & Antiviral \\
\hline Oxazepam & Antianxiety, sleep aid, sedative \\
\hline Oxycodone & Opioid analgesic, antitussive \\
\hline Paroxetine & Antidepressant, antianxiety \\
\hline Penciclovir & Antiviral \\
\hline Pentoxifylline & Vasodilator \\
\hline Phenazopyridine & Analgesic \\
\hline Phendimetrazine & Stimulant, appetite suppressant \\
\hline Phenytoin & Anticonvulsant, antiepileptic \\
\hline Piperonyl butoxide & Insecticidal synergist used in lice treatment \\
\hline Prednisolone & Glucocorticoid, antineoplastic \\
\hline Prednisone & Glucocorticoid, antineoplastic \\
\hline Promethazine & Antihistamine, antiemetic, sedative \\
\hline Propoxyphene & Opioid analgesic, antitussive \\
\hline Propranolol & Antihypertensive, antiarrhythmic, anxiolytic \\
\hline Pseudoephedrine + Ephedrine & Appetite suppressant, decongestant, stimulant \\
\hline Quinine & Antimalarial, flavorant, mild antipyretic, analgesic \\
\hline Ractopamine & Promotes leanness in animals raised for their meat \\
\hline Raloxifene & Anti-estrogen \\
\hline Ranitidine & Stomach-acid reducer \\
\hline Sertraline & Antidepressant, antianxiety \\
\hline Sitagliptin & Antihyperglycemic \\
\hline Sulfadimethoxine & Antibiotic \\
\hline Sulfamethizole & Antibiotic \\
\hline Sulfamethoxazole & Antibiotic \\
\hline Tamoxifen & Estrogen receptor agonist, breast cancer treatment \\
\hline Temazepam & Hypnotic \\
\hline Theophylline & Vasodilator \\
\hline Thiabendazole & Fungicide, nematicide \\
\hline Tiotropium & Bronchodilator \\
\hline Tramadol & Analgesic \\
\hline Triamterene & Diuretic \\
\hline Trimethoprim & Antibiotic \\
\hline Valacyclovir & Antiviral \\
\hline Venlafaxine & Antidepressant \\
\hline Verapamil & Antihypertensive, calcium channel blocker \\
\hline Warfarin & Anticoagulant, rodenticide \\
\hline
\end{tabular}

Kaua'i O'ahu Maui $\begin{gathered}\text { Hawai'i } i \\ \text { Island }\end{gathered}$

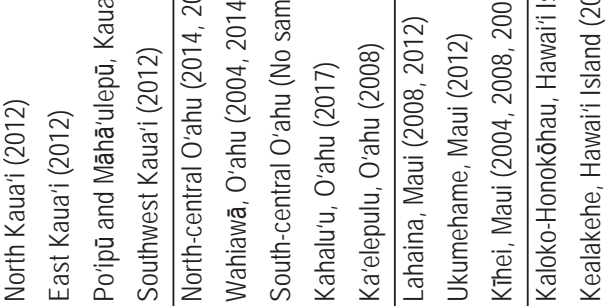

00000000000000

$0 \bigcirc \bigcirc \bigcirc 0000000000$

$\circ \bigcirc \bigcirc \bigcirc \bigcirc \bigcirc \bigcirc \bigcirc \bigcirc \bigcirc \bigcirc \bigcirc \bigcirc 0$

$0 \bigcirc 000000000000$

$0 \bigcirc 0 \bigcirc \bigcirc \bigcirc \circ 0000000$

00000000000000

00000000000000

00000000000000

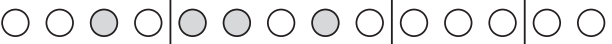

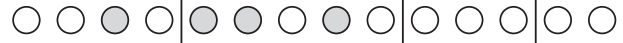

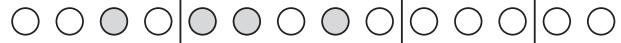

00000000000000

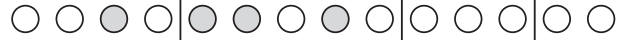

00000000000000

00000000000000

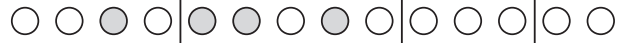

○ ○ 00000000000

00000000000000

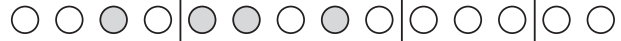

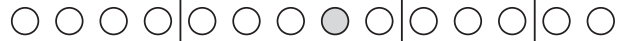

00000000000000

00000000000000

$0 \bigcirc 000000000000$

00000000000000

00000000010000

00000000000000

000000000100000

00000000000000

00000000000000

0 ○ ○ ○ 0000000000

00000000000000

00000000000000

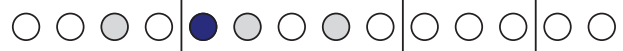

000000000100000

○ ○ ○ ○

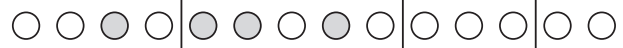

○ ○ ○ ○ ० 0000000

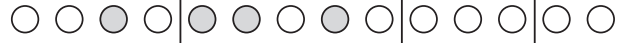

$000000000^{\prime} 0000$

Figure 15 (pages 41-43). - Continued 


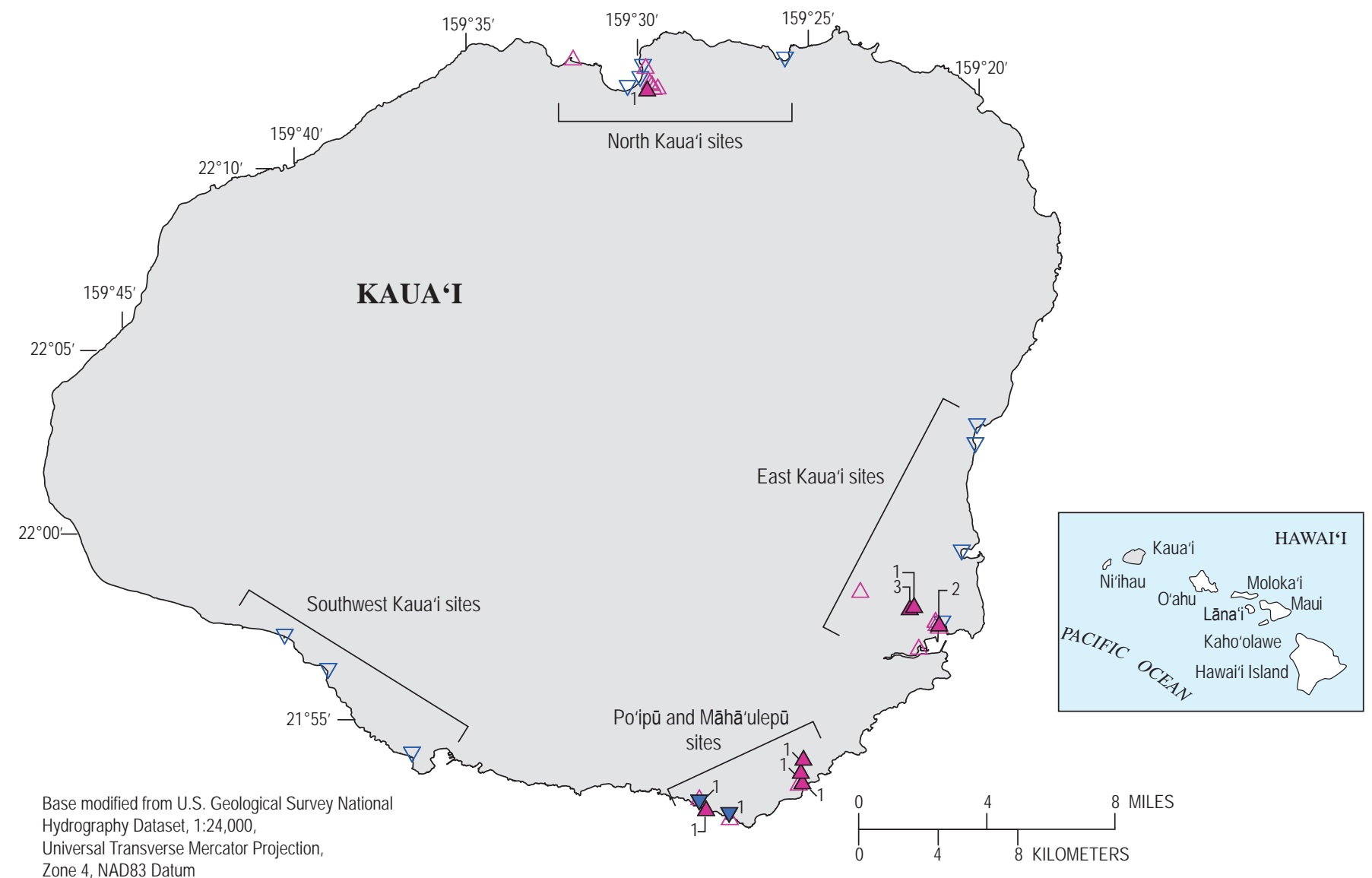

\section{EXPLANATION}

Sites where at least one pharmaceutical compound or organic-waste compound indicative of domestic wastewater was detected

${ }^{1} \triangle$ Surface-water sampling site and number of detections

Groundwater sampling site and number of detections
Sites where no pharmaceutical compounds or organic-waste compounds indicative of domestic wastewater were detected

$\triangle$ Surface-water sampling site

$\nabla$ Groundwater sampling site

Figure 16. Map showing general locations of sites on Kaua'i, Hawai'i, where groundwater and surface-water samples were collected during 2012-15 and then analyzed for organic-waste compounds and pharmaceutical compounds (see figs. 14, 15). Detections shown are limited to pharmaceutical and organic-waste compounds considered by Baldwin and others (2016) to be indicative of domestic wastewater. 


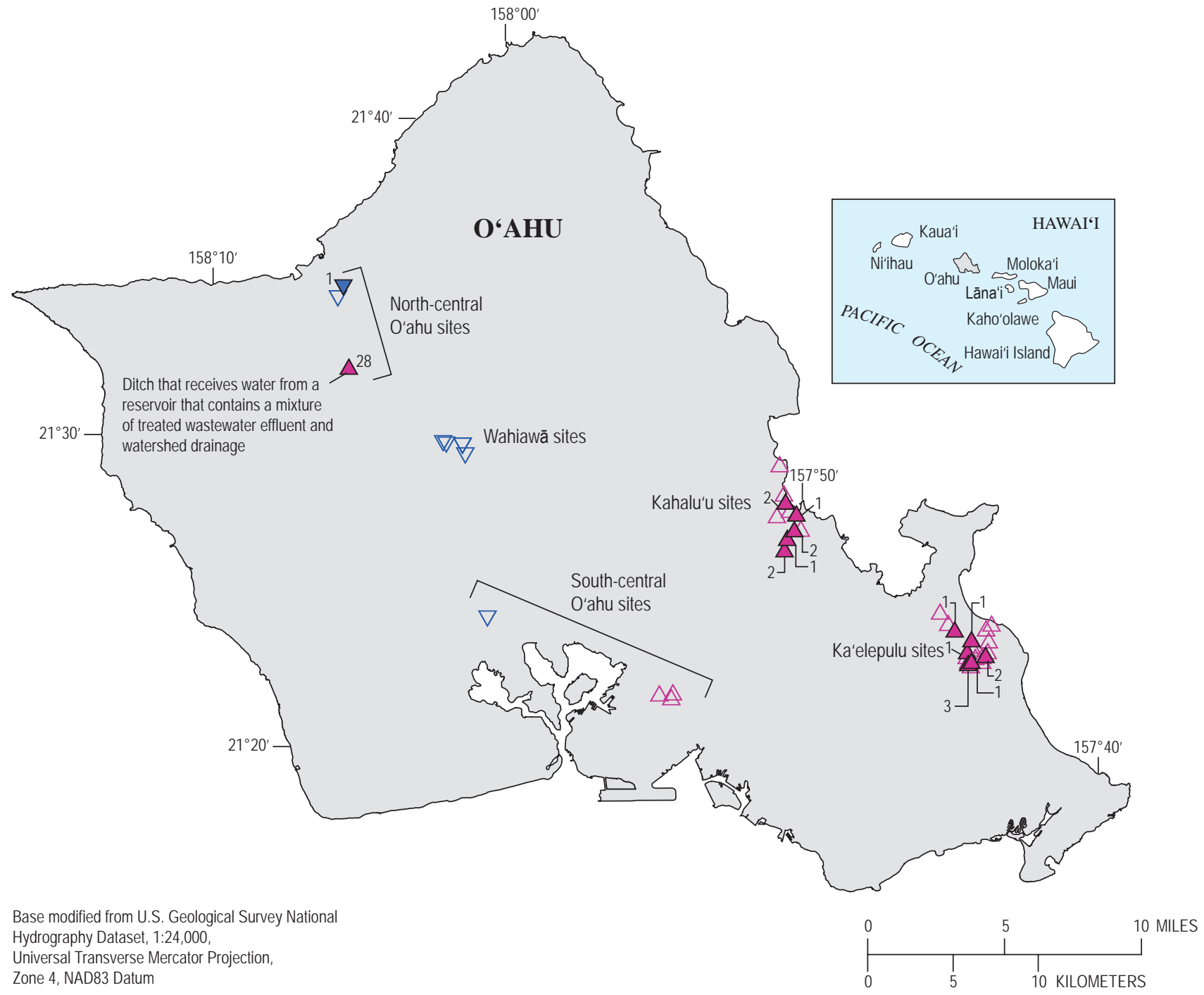

\section{EXPLANATION}

Sites where at least one pharmaceutical compound or organic-waste compound indicative of domestic wastewater was detected

${ }^{1} \triangle$ Surface-water sampling site and number of detections

$\nabla$ Groundwater sampling site and number of detections
Sites where no pharmaceutical compounds or organic-waste compounds indicative of domestic wastewater were detected

$\triangle$ Surface-water sampling site

$\nabla$ Groundwater sampling site

Figure 17. Map showing general locations of sites on O'ahu, Hawai'i, where groundwater and surface-water samples were collected during 2004-17 and then analyzed for organic-waste compounds, pharmaceutical compounds, or both (see figs. 14, 15). Detections shown are limited to pharmaceutical and organic-waste compounds considered by Baldwin and others (2016) to be indicative of domestic wastewater. 

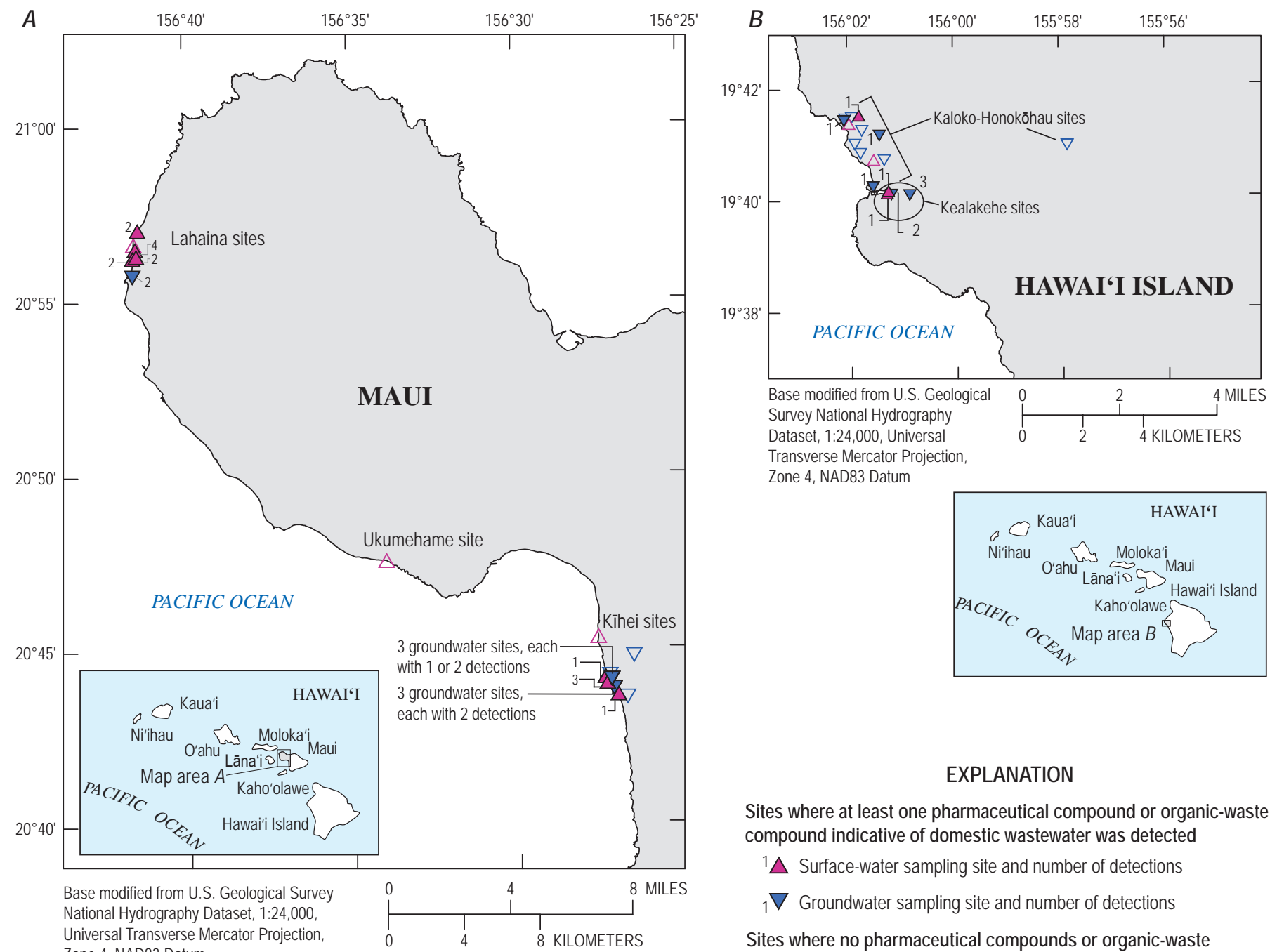

Transverse Mercator Projection, Zone 4, NAD83 Datum

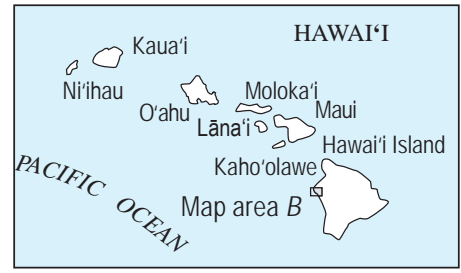

\section{EXPLANATION}

Sites where at least one pharmaceutical compound or organic-waste compound indicative of domestic wastewater was detected

${ }^{1} \triangle$ Surface-water sampling site and number of detections

${ }_{1} \nabla$ Groundwater sampling site and number of detections

Sites where no pharmaceutical compounds or organic-waste compounds indicative of domestic wastewater were detected

$\triangle$ Surface-water sampling site

$\nabla$ Groundwater sampling site

Figure 18. Maps showing general locations of sites where groundwater and surface-water samples were collected on Maui and on Hawai'i Island, Hawai'i, during 2004-12 and 2007-09, respectively, and then analyzed for organic-waste compounds and pharmaceutical compounds (see figs. 14, 15). Detections shown are limited to pharmaceutical and organic-waste compounds considered by Baldwin and others (2016) to be indicative of domestic wastewater.

organic-waste compounds are pesticides, which may originate from agricultural sources instead of wastewater. Six organicwaste compounds are polycyclic aromatic hydrocarbons, commonly called PAHs, which can originate from vehicle emissions, tire particles, motor oil, creosote-treated lumber, roofing tar, coal-tar-based pavement sealants, and other sources (Baldwin and others, 2015). Another organic-waste compound, tribromomethane, is produced naturally by macroalgae (Nightingale and others, 1995), and it also is a disinfection byproduct of water chlorination. Beach-park showers and leaky water pipes are two potential nonwastewater sources of chlorinated water in the environment. In their assessment of organic-waste compounds in tributaries of the Great Lakes of the northern United States and Canada, Baldwin and others (2016) considered 20 (shown in red in table 4) of the 69 organic-waste compounds to be indicators of domestic wastewater from sanitary-sewer sources.

The occurrence of organic-waste and pharmaceutical compounds in groundwater and surface-water samples collected at 14 general locations in Hawai'i between 2004 and 2017 are shown in figures 14 and 15. Results considered for figures 14 and 15 consist of those for all groundwater and surface-water samples that were available in NWIS (USGS, 2016) as of June 2019 and that were analyzed for either organic-waste compounds according to Zaugg and others (2007a, b) or pharmaceutical compounds according to Furlong 
and others $(2008,2014)$, or both. The results include those for samples collected for past CWB-USGS source-tracking efforts (table 1), if available, as well as results for sampling efforts not shown in table 1 . The general locations did not have the same number of sampling sites; the number of sites per general location ranged from 1 to 20 (figs. 16-18). One or two samples per site were collected at the Kaloko-Honokōhau general location, and only one sample per site was collected at the remaining general locations. Each result considered a detection did not have a "<" or "V" remark, did not have a " $v$ " value qualifier, and had a concentration that exceeded the compound's detection level (shown in table 4 or 5). Figures 16,17 , and 18 show the sampling sites where at least one pharmaceutical compound (other than atrazine), or at least one of the 20 organic waste compounds considered by Baldwin and others (2016) to be indicative of domestic wastewater, was detected. The site that had the most detections (28) is a ditch on $\mathrm{O}^{\prime}$ ahu (fig. 17) that receives water from a reservoir containing a mixture of treated wastewater effluent and watershed drainage.

The use of organic-waste and pharmaceutical compounds for source-tracking efforts has some limitations. Wastewater could be present even if no compounds are detected in water samples because the compounds can degrade in wastewatertreatment systems and in the environment. Also, the compounds may be present in the environment but at concentrations that are too low for laboratories to identify. And finally, many organic-waste compounds may originate from watershed sources other than wastewater (table 4).

\section{Developing Conclusions}

Investigators evaluating whether wastewater is present at their sampling sites, where it might be originating, and how it is moving through the environment can develop conclusions by collectively considering all the background information, measurements, and chemical-tracer results. A summary table and map of the sampling sites can help develop broader conclusions about where wastewater is found in a study area and where it might be originating. The map label for each site can indicate the conclusion of wastewater presence or absence, as well as the line of evidence that supports the conclusion. If more than one round of samples was collected at a site during different conditions, then investigators might be able to infer the conditions in which wastewater is present in the study area.

Supporting evidence of wastewater presence at sampling sites includes (1) the presence of optical brighteners; (2) enrichment of one or more nutrients, as inferred by mixing plots of each nutrient and SC; (3) the presence of tap water or wastewater effluent, as inferred from mixing plots of water $\delta^{2} \mathrm{H}, \delta^{18} \mathrm{O}$, and $\mathrm{SC}$ values; (4) the presence of nitrate that appears to originate from wastewater, as inferred by elevated nitrate $\delta^{15} \mathrm{~N}$ values combined with either elevated nitrate concentrations or elevated nitrate enrichment values, or both; (5) the detection of organic-waste compounds that are potential indicators of wastewater; and (6) the detection of pharmaceutical compounds.

Supporting evidence of wastewater absence and the possible presence of animal waste in water at sampling sites includes (1) the absence of optical brighteners; (2) enrichment of one or more nutrients, as inferred by mixing plots of each nutrient and SC; (3) elevated nitrate $\delta^{15} \mathrm{~N}$ values, combined with either elevated nitrate concentrations or elevated nitrateenrichment values, or both; (4) the absence of organic-waste compounds that are potential indicators of wastewater; and (5) the absence of pharmaceutical compounds.

In general, the more lines of evidence of wastewater presence at each site, the more confidence investigators can gain in their conclusions. Of all lines of evidence, the presence of several detected pharmaceutical compounds is arguably the most definitive indicator of wastewater because these compounds are used and excreted by humans. The observed enrichment of one or more nutrients is a less diagnostic indicator of wastewater because nutrients in water can originate from nonwastewater sources, including fertilizers, animal fecal matter, nitrogen-fixing bacteria in vegetation, and atmospheric deposition. Lastly, investigators would ensure that their conclusions are consistent with background information for their study area. They also would consider the limitations for each wastewater tracer.

\section{Suggestions for Future Studies}

Future studies might consider the use of additional chemical tracers of wastewater, such as artificial sweeteners, if these tracers can be reliably and accurately measured by laboratories. Boron isotopes can be considered as additional wastewater tracers, although they may not be useful in study areas where waters contain more than 15 to 20 percent ocean water (Hunt, 2014). Future studies may also consider the use of accumulation-type passive samplers (see, for example, Alvarez and others, 2014). An advantage of passive samplers is that they can accumulate pharmaceutical compounds and organicwaste compounds that are not continuously present in water.

Future studies also might consider the use of enzymelinked immunosorbent assays to analyze reconnaissance samples for selected tracers such as carbamazepine and sulfamethoxazole. The source-tracking approach presented here may guide the efforts of investigators that use microbial source-tracking techniques (see, for example, Dubinsky and others, 2016; Kirs and others, 2016, 2017).

\section{Summary}

Elevated concentrations of nutrients and the fecalindicator bacteria enterococci that exceed water-quality standards are occasionally detected in Hawai' i's surface waters by the State of Hawai'i Department of Health Clean Water Branch. Efforts to remediate contamination in surface waters are complicated by the fact that nutrients and enterococci 
bacteria can originate from several sources, including human fecal matter in wastewater, animal fecal matter, and fertilizers. Enterococci bacteria, prevalent in the fecal matter of humans, also are prevalent in the fecal matter of many other animals that inhabit watersheds in Hawai' $i$, and they have been found growing in Hawai'i's soils. Wastewater often is the suspected source of elevated nutrients and enterococci detected in the environment. The presence of wastewater in the environment, however, may not be definitively known from the routine monitoring employed by the State of Hawai'i Department of Health Clean Water Branch.

This report describes a source-tracking approach that can help investigators determine whether or not wastewater is present in water in the environment and, if present, where it might be originating. The source-tracking approach proposes a sequence of five steps that involve gathering background information, conducting trolling-instrument surveys of physical properties of surface water, collecting water samples at reconnaissance sites and then analyzing the samples for specific conductance and optical brighteners, collecting water samples at targeted sites and having appropriate laboratories analyze the samples for multiple chemical tracers of wastewater, and evaluating analytical results of the chemical tracers in the samples. In general, the more lines of evidence of wastewater presence at each site, the more confidence investigators can gain in their conclusions. The source-tracking approach presented in this report can guide management and stakeholder efforts to protect the health of recreational water users, protect the quality of Hawai'i's water resources, and remediate waterquality problems.

\section{References Cited}

Alvarez, D.A., Maruya, K.A., Dodder, N.G., Lao, W., Furlong, E.T., and Smalling, K.L., 2014, Occurrence of contaminants of emerging concern along the California coast (2009-10) using passive sampling devices: Marine Pollution Bulletin, v. 81 , no. 2 , p. 347-354, accessed January 22, 2020, at https://doi.org/10.1016/j.marpolbul.2013.04.022.

Asner, G.P., Hughes, R.F., Vitousek, P.M., Knapp, D.E., Kennedy-Bowdoin, T., Boardman, J., Martin, R.E., Eastwood, M., and Green, R.O., 2008, Invasive plants transform the three-dimensional structure of rain forests: Proceedings of the National Academy of Sciences, v. 105, no. 11, p. 4519-4523.

Baldwin, A.K., Corsi, S.R., De Cicco, L.A., Lenaker, P.L., Lutz, M.A., Sullivan, D.J., and Richards, K.D., 2016, Organic contaminants in Great Lakes tributariesPrevalence and potential aquatic toxicity: Science of the Total Environment, v. 554-555, p. 42-52, accessed December 20, 2018, at https://doi.org/10.1016/j. scitotenv.2016.02.137.
Baldwin, A.K., Corsi, S.R., Magruder, C., Magruder, M., and Bruce, J.L., 2015, Organic waste compounds as contaminants in Milwaukee-area streams: U.S. Geological Survey Fact Sheet 2015-3056, 4 p., accessed December 20, 2018, at https://doi.org/10.3133/fs20153056.

Barron, V., Herruzo, M., and Torrent, J., 1988, Phosphate adsorption by aluminous hematites of different shapes: Soil Science Society of America Journal, v. 52, no. 3, p. 647-651.

Bexfield, L.M., Toccalino, P.L., Belitz, K., Foreman, W.T., and Furlong, E.T., 2019, Hormones and pharmaceuticals in groundwater used as a source of drinking water across the United States: Environmental Science \& Technology, v. 53, no. 6, p. 2950-2960, accessed March 19, 2019, at https:// doi.org/10.1021/acs.est.8b05592.

Burns, D.A., Boyer, E.W., Elliott, E.M., and Kendall, C.K., 2009 , Sources and transformations of nitrate from streams draining varying land uses-Evidence from dual isotope analysis: Journal of Environmental Quality v. 38, no. 3, p. 1149-1159, accessed September 21, 2018, at https://doi. org/10.2134/jeq2008.0371.

Byappanahalli, M.N., Roll, B.M., and Fujioka, R.S., 2012, Evidence for occurrence, persistence, and growth potential of Escherichia coli and enterococci in Hawaii's soil environments: Microbes and Environments, v. 27, no. 2, p. 164-170, accessed May 17, 2018, at https://doi.org/10.1264/ jsme2.ME11305.

Cao, Y., Griffith, J.F., and Weisberg, S.B., 2009, Evaluation of optical brighteners photodecay characteristics for the detection of human fecal contamination: Water Research, v. 43, no. 8, p. 2273-2279, accessed January 23, 2020, at https://doi.org/10.1016/j.watres.2009.02.020.

Carrillo, J.H., Hastings, M.G., Sigman, D.M., and Huebert, B.J., 2002, Atmospheric deposition of inorganic and organic nitrogen and base cations in Hawaii: Global Biochemical Cycles, v. 16, no. 4, p. 24-1-24-16, accessed April 26, 2019, at https://doi.org/10.1029/2002GB001892.

Chadwick, O.A., Derry, L.A., Vitousek, P.M., Huebert, B.J., and Hedin, L.O., 1999, Changing sources of nutrients during four million years of ecosystem development: Nature, v. 397, p. 491-497, accessed April 26, 2019, at https://www.nature.com/articles/17276.

Childress, C.J.O., Foreman, W.T., Connor, B.F., and Maloney, T.J., 1999, New reporting procedures based on long-term method detection levels and some considerations for interpretations of water-quality data provided by the U.S. Geological Survey National Water Quality Laboratory: U.S. Geological Survey Open-File Report 99-193, 19 p., accessed June 9, 2016, at https://doi.org/10.3133/ofr99193. 
Cincinelli, A., Stortini, A.M., Perugini, M., Checchini, L., and Lepri, L., 2001, Organic pollutants in sea-surface microlayer and aerosol in the coastal environment of Leghorn (Tyrrhenian Sea): Marine Chemistry, v. 76, no. 1-2, p. 77-98, accessed October 25, 2019, at https://doi. org/10.1016/S0304-4203(01)00049-4.

Coplen, T.B., Qi, H., Révész, K., Casciotti, K., and Hannon, J.E., 2012, Determination of the $\delta^{15} \mathrm{~N}$ and $\delta^{18} \mathrm{O}$ of nitrate in water; RSIL lab code 2900, in Révész, K., and Coplen, T.B., eds., Methods of the Reston Stable Isotope Laboratory (slightly revised from version 1.0 [2007]): U.S. Geological Survey Techniques and Methods, book 10, chap. C17, 35 p., accessed June 13, 2019, at https://pubs.usgs.gov/tm/2006/ $\operatorname{tm} 10 \mathrm{c} 17 /$.

Cornell, S., Mace, K., Coeppicus, S., Duce, R., Huebert, B., Jickells, T., and Zhuang, L.-Z., 2001, Organic nitrogen in Hawaiian rain and aerosol: Journal of Geophysical Research, v. 106, no. D8, p. 7973-7983, accessed April 26, 2019, at https://doi.org/10.1029/2000JD900655.

County of Kaua'i Department of Water, 2016, Water quality report covering the period of January 1, 2015 to December 31, 2015, Kalaheo-Koloa Water System: County of Kaua' $i$ Department of Water Quality Report, 15 p.

Desmarais, T.R., Solo-Gabriele, H.M., and Palmer, C., 2002, Influence of soil on fecal indicator organisms in a tidally influenced subtropical environment: Applied and Environmental Microbiology, v. 68, no. 3, p. 1165-1172, accessed May 11, 2018, at https://doi.org/10.1128\%2F AEM.68.3.1165-1172.2002.

Dubinsky, E.A., Butkus, S.R., and Andersen, G.L., 2016, Microbial source tracking in impaired watersheds using PhyloChip and machine-learning classification: Water Research, v. 105, p. 56-64, accessed May 14, 2018, at https://doi.org/10.1016/j.watres.2016.08.035.

Fackrell, J.K., 2016, Geochemical evolution of Hawaiian groundwater: Honolulu, University of Hawai'i at Mānoa, Ph.D. dissertation, 160 p., accessed July 16, 2020, at https:// hdl.handle.net/10125/51484.

Fishman, M.J., ed., 1993, Methods of analysis by the U.S. Geological Survey National Water Quality LaboratoryDetermination of inorganic and organic constituents in water and fluvial sediments: U.S. Geological Survey OpenFile Report 93-125, 217 p., accessed April 30, 2019, at https://pubs.er.usgs.gov/publication/ofr93125.

Fox, R.L., and Searle, P.G.E., 1978, Phosphate adsorption by soils of the tropics, chap. 7 in Drosdoff, M., Daniels, R.B., and Nicholaides, J.J., III, eds., Diversity of soils in the tropics: Madison, Wis., Soil Science Society of America, American Society of Agronomy Special Publication 34, p. 97-119.
Furlong, E.T., Batt, A.L., Glassmeyer, S.T., Noriega, M.C., Kolpin, D.W., Mash, H., and Schenck, K.M., 2017, Nationwide reconnaissance of contaminants of emerging concern in source and treated drinking waters of the United StatesPharmaceuticals: Science of the Total Environment, v. 579, p. 1629-1642, accessed January 22, 2020, at https://doi. org/10.1016/j.scitotenv.2016.03.128.

Furlong, E.T., Noriega, M.C., Kanagy, C.J., Kanagy, L.K., Coffey, L.J., and Burkhardt, M.R., 2014, Determination of human-use pharmaceuticals in filtered water by direct aqueous injection-high-performance liquid chromatography/ tandem mass spectrometry: U.S. Geological Survey Techniques and Methods, book 5, chap. B10, 49 p., accessed June 20, 2019, at https://doi.org/10.3133/tm5B10.

Furlong, E.T., Werner, S.L., Anderson, B.D., and Cahill, J.D., 2008, Determination of human-health pharmaceuticals in filtered water by chemically modified styrenedivinylbenzene resin-based solid-phase extraction and highperformance liquid chromatography/mass spectrometry: U.S. Geological Survey Techniques and Methods, book 5, chap. B5, 56 p., accessed June 20, 2019, at https://pubs. usgs.gov/tm/tm5b5/.

Gibs, J., Wilde, F.D., and Heckathorn, H.A., 2012, Use of multiparameter instruments for routine field measurements (ver. 1.1): U.S. Geological Survey Techniques of WaterResources Investigations, book 9, chap. A6, accessed October 2019 at https://doi.org/10.3133/twri09A6.8.

Goto, D.K., and Yan, T., 2011, Effects of land uses on fecal indicator bacteria in the water and soil of a tropical watershed: Microbes and Environments, v. 26, no. 3, p. 254-260, accessed May 17, 2018, at https://doi.org/10.1264/ jsme2.ME11115.

Granger, J., Sigman, D.M., Needoba, J.A., and Harrison, P.J., 2004, Coupled nitrogen and oxygen isotope fractionation of nitrate during assimilation by cultures of marine phytoplankton: Limnology and Oceanography, v. 49, no. 5, p. 1763-1773.

Halley, R.B., and Yates, K.K., 2008, Light, calcification, and carbonate sediment production on the Moloka'i reef flat, chap. 14 of Field, M.E., Cochran, S.A., Logan, J.B., and Storlazzi, C.D., eds., The coral reef of south Moloka 'i, Hawai i-Portrait of a sediment-threatened fringing reef: U.S. Geological Survey Scientific Investigations Report 2007-5101, p. 117-120, accessed January 23, 2020, at https://pubs.usgs.gov/sir/2007/5101/.

Hardina, C.M., and Fujioka, R.S., 1991, Soil-The environmental source of Escherichia coli and enterococci in Hawaii's streams: Environmental Toxicology and Water Quality, v. 6, p. 185-195. 
Hardy, J.T., 1982, The sea surface microlayer-Biology, chemistry and anthropogenic enrichment: Progress in Oceanography. v. 11, no. 4, p. 307-328, accessed October 25, 2019, at https://doi.org/10.1016/0079-6611(82)90001-5.

Hardy, J.T., Crecelius, E.A., Antrim, L.D., Kiesser, S.L, Broadhurst, V.L., Boehm, P.D., Steinhauer, W.G., and Coogan, T.H., 1990, Aquatic surface microlayer contamination in Chesapeake Bay: Marine Chemistry, v. 28, no. 4, p. 333-351, accessed October 25, 2019, at https://doi. org/10.1016/0304-4203(90)90052-E.

Horowitz, A.J., Sandstrom, M.W., and Wilde, F.D., 2004, Quality control for equipment-cleaning procedures, sec. 3.4 in Wilde, F.D., ed., Cleaning of equipment for water sampling (ver. 2.0): U.S. Geological Survey Techniques of Water-Resources Investigations, book 9, chap. A, accessed January 23, 2020, at https://pubs.water.usgs.gov/twri9A3/.

Hunt, C.D., Jr., 2007, Ground-water nutrient flux to coastal waters and numerical simulation of wastewater injection at Kihei, Maui, Hawaii: U.S. Geological Survey Scientific Investigations Report 2006-5283, 69 p., accessed March 2, 2009, at https://pubs.usgs.gov/sir/2006/5283/.

Hunt, C.D., Jr., 2014, Baseline water-quality sampling to infer nutrient and contaminant sources at Kaloko-Honokōhau National Historical Park, Island of Hawai' $i$, 2009: U.S. Geological Survey Scientific Investigations Report 2014-5158, 52 p., accessed January 23, 2020, at https://doi. org/10.3133/sir20145158.

Hunt, C.D., Jr., and Rosa, S.N., 2009, A multi-tracer approach to detecting wastewater plumes from municipal injection wells in nearshore marine waters at Kihei and Lahaina, Maui, Hawaii: U.S. Geological Survey Scientific Investigations Report 2009-5253, 166 p., accessed February 16, 2010, at https://pubs.usgs.gov/sir/2009/5253/.

Johnson, A.G., Glenn, C.R., Burnett, W.C., Peterson, R.N., and Lucey, P.G., 2008, Aerial infrared imaging reveals large nutrient-rich groundwater inputs to the ocean: Geophysical Research Letters, v. 35, no. 15, 6 p., accessed January 23, 2020, at https://doi.org/10.1029/2008GL034574.

Kay, E.A., Lau, L.S., Stroup, E.D., Dollar, S.J., Fellows, D.P., and Young, R.H.F., 1977, Hydrologic and ecologic inventories of the coastal waters of west Hawaii: Honolulu, Hawaii, University of Hawaii at Manoa, Water Resources Center Technical Report No. 105, 94 p., accessed July 16, 2020, at https://hdl.handle.net/10125/2590.

Kelly, J.K., Dulai, H., Glenn, C.R., and Lucey, P.G., 2019, Integration of aerial infrared thermotography and in situ radon-222 to investigate submarine groundwater discharge to Pearl Harbor, Hawaii, USA: Limnology and Oceanography, v. 64, p. 238-257, accessed January 28, 2019, at https://doi.org/10.1002/lno.11033.
Kelly, J.L., Glenn, C.R., and Lucey, P.G., 2013, High-resolution aerial infrared mapping of groundwater discharge to the coastal ocean: Limnology and Oceanography Methods, v. 11 , no. 5, p. 262-277, accessed January 23, 2020, at https://doi.org/10.4319/lom.2013.11.262.

Kendall, C., 1998, Tracing nitrogen sources and cycling in catchments, in Kendall, C., and McDonnell, J.J., eds., Isotope tracers in catchment hydrology: Amsterdam, Netherlands, Elsevier Science, p. 519-576.

Kendall, C., and Caldwell, E.A., 1998, Fundamentals of isotope geochemistry, in Kendall, C., and McDonnell, J.J., eds., Isotope tracers in catchment hydrology: Amsterdam, Netherlands, Elsevier Science, p. 51-86.

Kendall, C., Elliot, E.M., and Wankel, S.D., 2007, Tracing anthropogenic inputs of nitrogen to ecosystems, in Michener, R., and Lajtha, K., eds., Stable isotopes in ecology and environmental science: Malden, Mass., Blackwell Publishing, $595 \mathrm{p}$.

Kirs, M., Caffaro-Filho, R.A., Wong, M., Harwood, V.J., Moravcik, P., and Fujioka, R.S., 2016, Human-associated Bacteroides spp. and human polyomaviruses as microbial source tracking markers in Hawaii: Applied and Environmental Microbiology, v. 82, no. 22, p. 6757-6767, accessed May 16, 2018, at https://doi.org/10.1128/AEM.01959-16.

Kirs, M., Kisand, V., Wong, M., Caffaro-Filho, R.A., Moravcik, P., Harwood, V.J., Yoneyama, B., and Fujioka, R.S., 2017, Multiple lines of evidence to identify sewage as the cause of water quality impairment in an urbanized tropical watershed: Water Research, v. 116, p. 23-33, accessed May 16, 2018, at https://doi.org/10.1016/j. watres.2017.03.024.

Knee, K.L., Blythe, A.L, Street, J.H., Boehm, A.B., and Payton, A., 2008, Sources of nutrients and fecal indicator bacteria to nearshore water on the North Shore of Kaua' $i$ (Hawai' ${ }^{\prime}$, USA): Estuaries and Coasts, v. 31, p. 602-622, accessed May 17, 2019, at https://doi.org/10.1007/s12237008-9055-6.

Knowles, R., 1982, Denitrification: Microbiological Reviews, v. 46 , no. 1 , p. $43-70$.

Kramer, J.B., Canonica, S., Hoigné, J., and Kaschig, J., 1996, Degradation of fluorescent whitening agents in sunlit natural waters: Environmental Science \& Technology, v. 30, no. 7, p. 2227-2234, accessed March 20, 2019, at https://doi. org/10.1021/es950711a.

Kurtz, A.C., Derry, L.A., and Chadwick, O.A., 2001, Accretion of Asian dust to Hawaiian soils-Isotopic, elemental, and mineral mass balances: Geochemica et Cosmochimica Acta, v. 65, no. 12, p. 1971-1983. 
Lee, E., Yoon, H., Hyun, S.-P., Burnett, W.C., Koh, D.-C., Ha, K., Kim, D., Kim, Y., and Kang, K., 2016, Unmanned aerial vehicles (UAVs)-based thermal infrared (TIR) mapping, a novel approach to assess groundwater discharge into the coastal zone: Limnology and Oceanography - Methods, v. 14, no. 11, p. 725-735, accessed April 25, 2019, at https:// doi.org/10.1002/lom3.10132.

Lewis, M.E., and Zaugg, S.D., 2003, Wastewater, pharmaceutical, and antibiotic compounds (ver. 1.1), sec. 5.6.1.F in Wilde, F.D., ed., Processing of water samples (ver. 2.0): U.S. Geological Survey Techniques of Water-Resources Investigations, book 9, chap. A5., accessed April 2019 at https:/pubs.water.usgs.gov/twri9A5/.

Libes, S.M., 1992, An introduction to marine biogeochemistry: Hoboken, N.J., John Wiley \& Sons, Inc., 734 p.

Luther, K., and Fujioka, R., 2004, Usefulness of monitoring tropical streams for male-specific RNA coliphages: Journal of Water and Health, v. 2, no. 3, p. 171-181.

Mallin, M.A., Williams, K.E., Esham, E.C., and Lowe, R.P., 2000, Effect of human development on bacteriological water quality in coastal watersheds: Ecological Applications, v. 10, no. 4, p. 1047-1056, accessed September 14, 2018, at https://doi.org/10.2307/2641016.

McGuire, K., and McDonnell, J., 2007, Stable isotope tracers in watershed hydrology, in Michener, R., and Lajtha, K., eds., Stable isotopes in ecology and environmental science: Malden, Mass., Blackwell Publishing, 595 p.

McLaughlin, J.R., Ryden, J.C., and Syers, J.K., 1981, Sorption of inorganic phosphate by iron- and aluminum-containing components: Journal of Soil Science, v. 32, no. 3, p. 365-377.

Melrose, J., Perroy, R., and Cares, S., 2016, Statewide agricultural land use baseline 2015: Hilo, University of Hawai'i at Hilo, Spatial data analysis and Visualization Lab, prepared for Hawai'i Department of Agriculture, accessed January 23, 2020, at https://hdoa.hawaii.gov/salub/ (dataset available at https://planning.hawaii.gov/gis/download-gisdata-expanded/).

Mueller, D.K., Schertz, T.L., Martin, J.D., and Sandstrom, M.W., 2015, Design, analysis, and interpretation of field quality-control data for water-sampling projects: U.S. Geological Survey Techniques and Methods, book 4, chap. C4, 54 p., accessed January 23, 2020, at https://doi. org/10.3133/tm4C4.

Nightingale, P.D., Malin, G, and Liss, P.S., 1995, Production of chloroform and other low-molecular-weight halocarbons by some species of macroalgae: Limnology and Oceanography, v. 40, p. 680-689.

Oshiro, R., and Fujioka, R., 1995, Sand, soil, and pigeon droppings - Sources of indicator bacteria in the waters of Hanauma Bay, Oahu, Hawaii: Water Science Technology, v. 31, no. 5-6, p. 251-254, accessed January 21, 2020, at https://doi.org/10.1016/0273-1223(95)00275-R.
Parfitt, R.L., Atkinson, R.J., and Smart, R.St.C., 1975, The mechanism of phosphate fixation by iron oxides: Soil Science Society of America Proceedings, v. 39, p. 837-841.

Patton, C.J., and Kryskalla, J.R., 2003, Methods of analysis by the U.S. Geological Survey National Water Quality Laboratory, evaluation of alkaline persulfate digestion as an alternative to Kjeldahl digestion for determination of total and dissolved nitrogen and phosphorus in water: U.S. Geological Survey Water-Resources Investigations Report 03-4174, 33 p., accessed April 30, 2019, at https://doi. org/10.3133/wri034174.

Patton, C.J., and Kryskalla, J.R., 2011, Colorimetric determination of nitrate plus nitrite in water by enzymatic reduction, automated discrete analyzer methods: U.S. Geological Survey Techniques and Methods, book 5, chap. B8, 34 p., accessed April 30, 2019, at https://doi.org/10.3133/tm5B8.

Peterson, R.N., Burnett, W.C., Glenn, C.R., and Johnson, A.G., 2009, Quantification of point-source groundwater discharges to the ocean from the shoreline of the Big Island, Hawaii: Limnology and Oceanography, v. 54, no. 3, p. 890904, accessed January 23, 2020, at https://doi.org/10.4319/ lo.2009.54.3.0890.

Révész, K., and Coplen, T.B., 2008a, Determination of the $\delta\left({ }^{2} \mathrm{H} /{ }^{1} \mathrm{H}\right)$ of water-RSIL lab code 1574 , in Révész, K., and Coplen, T.B., eds., Methods of the Reston Stable Isotope Laboratory: U.S. Geological Survey Techniques and Methods, book 10, chap. C1, 27 p., accessed April 30, 2019, at https://doi.org/10.3133/tm10C1.

Révész, K., and Coplen, T.B., 2008b, Determination of the $\delta\left({ }^{18} \mathrm{O} /{ }^{16} \mathrm{O}\right)$ of water-RSIL lab code 489 , in Révész, K., and Coplen, T.B., eds., Methods of the Reston Stable Isotope Laboratory: U.S. Geological Survey Techniques and Methods, book 10, chap. C2, 28 p., accessed April 30, 2019, at https://doi.org/10.3133/tm10C2.

Romanok, K.M., Bradley, P.M., and Battaglin, W.A., 2018, Occurrence data for organic compounds and bioactive chemicals in water, sediment and tissue from Rocky Mountain National Park, 2012-13: U.S. Geological Survey data release, accessed November 7, 2018, at https://doi. org/10.5066/P9XUYMQT.

Sandstrom, M.W., and Wilde, F.D., 2014, Syringe-filter procedure for processing samples for analysis of organic compounds by DAI LC-MS/MS (ver. 3.1), sec. 5.2.2.B in Wilde, F.D., ed., Processing of water samples (ver. 2.0): U.S. Geological Survey Techniques of Water-Resources Investigations, book 9, chap. A5, sec. 5.2.2.B, accessed May 2019 at http://pubs.water.usgs.gov/twri9A5/.

Scholl, M.A., Gingerich, S.B., and Tribble, G.A., 2002, The influence of microclimates and fog on stable isotope signatures used in interpretation of regional hydrologyEast Maui, Hawaii: Journal of Hydrology, v. 264, nos. 1-4, p. 170-184, accessed January 23, 2020, at https://doi. org/10.1016/S0022-1694(02)00073-2. 
Scholl, M.A., Ingebritsen, S.E., Janik, C.J., and Kauahikaua, J.P., 1996, Use of precipitation and groundwater isotopes to interpret regional hydrology on a tropical volcanic islandKilauea volcano area, Hawaii: Water Resources Research, v. 32, no. 12, p. 3525-3537, accessed January 23, 2020, at https://doi.org/10.1029/95WR02837.

Skrobialowski, S.C., 2016, Capsule- and disk-filter procedure (ver. 3.0), sec. 5.2.1.A in Wilde, F.D., ed., Processing of water samples (ver. 2.0): U.S. Geological Survey Techniques of Water-Resources Investigations, book 9, chap. A5, accessed May 2019 at https://pubs.water.usgs.gov/twri9A5/.

State of Hawaii, 1976, Land use and land cover of the main Hawaiian Islands as of 1976: State of Hawaii digital dataset [available as of June 2019], accessed January 23, 2020, at https://planning.hawaii.gov/gis/download-gis-dataexpanded/.

State of Hawai'i, 2014, Hawai'i administrative rules, title 11: State of Hawai'i Department of Health, chapter 54, water quality standards, accessed September 19, 2016, at https:// health.hawaii.gov/cwb/files/2013/04/Clean_Water_Branch_ HAR_11-54_20141115.pdf.

State of Hawai'i, 2017, 2016 State of Hawaii water quality monitoring and assessment report-Integrated report to the U.S. Environmental Protection Agency and the U.S. Congress Pursuant to $\S 303(\mathrm{~d})$ and $\S 305(\mathrm{~b})$, Clean Water Act (P.L. 97-117): State of Hawai'i Department of Health Clean Water Branch.

Tetra Tech, Inc., 2004, Sanitary Surveys in Hawaii-A framework: Tetra Tech, Inc., Report prepared for U.S. Environmental Protection Agency Region IX and Hawaii Department of Health, 38 p., accessed on May 11, 2018, at https:/health.hawaii.gov/cwb/files/2015/04/HawaiiSanitary-Survey-Framework_Revised_FINAL.pdf.

Tillman, F.D, Oki, D.S., and Johnson, A.G., 2014a, Waterchemistry data collected in and near Kaloko-Honokōhau National Historical Park, Hawai ‘i, 2012-2014: U.S. Geological Survey Open-File Report 2014-1173, 14 p., accessed at https://doi.org/10.3133/ofr20141173.

Tillman, F.D, Oki, D.S., Johnson, A.G., Barber, L.B., and Beisner, K.R., 2014b, Investigation of geochemical indicators to evaluate the connection between inland and coastal groundwater systems near Kaloko-Honokohau National Historical Park, Hawaii: Applied Geochemistry, v. 51, p. 278-292, accessed January 23, 2020, at https://doi. org/10.1016/j.apgeochem.2014.10.003.

Urish, D.W., and McKenna, T.E., 2004, Tidal effects on ground water discharge through a sandy marine beach: Ground Water, v. 42, no. 7, p. 971-982, accessed April 25, 2019, at https://doi.org/10.1111/j.1745-6584.2004. tb02636.x.
U.S. Environmental Protection Agency, 2012, 2012 recreational water quality criteria: U.S. Environmental Protection Agency Fact Sheet EPA 820-F-12-058, 2 p., accessed September 11, 2018, at https:/www.epa.gov/wqc/2012recreational-water-quality-criteria-documents.

U.S. Geological Survey [USGS], 2006, Collection of water samples (ver. 2.0): U.S. Geological Survey Techniques of Water-Resources Investigations, book 9, chap. A4, accessed May 2019 at http://pubs.water.usgs.gov/twri9A4/.

U.S. Geological Survey [USGS], 2014, Updated policy for the evaluation and approval of analytical laboratory performance for water mission area projects and programs: U.S. Geological Survey Office of Water Quality Technical Memorandum 2014.01, accessed July 8, 2019, at https:// water.usgs.gov/admin/memo/QW/qw2014.01.pdf.

U.S. Geological Survey [USGS], 2016, USGS water data for the Nation: U.S. Geological Survey National Water Information System website, accessed July 17, 2020, at https://doi.org/10.5066/F7P55KJN.

U.S. Geological Survey [USGS], 2019, Specific conductance: U.S. Geological Survey Techniques and Methods, book 9 , chap. A6.3, 15 p., accessed April 25, 2019, at https://doi. org/10.3133/tm9A6.3.

Viau, E.J., Goodwin, K.D., Yamahara, K.M., Layton, B.A., Sassoubre, L.M., Burns, S.L., Tong, H., Wong, S.H.C., Lu, Y., and Boehm, A.B., 2011, Bacterial pathogens in Hawaiian coastal streams-Associations with fecal indicators, land cover, and water quality: Water Research, v. 45, p. 3279-3290.

Vitousek, P.M., Walker, L.R., Whiteaker, L.D., MuellerDombois, D., and Matson, P.A., 1987, Biological invasion of Myrica faya alters ecosystem development in Hawaii: Science, v. 238 , no. 4828 , p. $802-804$.

Wagner, R.J., Boulger, R.W., Jr., Oblinger, C.J., and Smith, B.A., 2006, Guidelines and standard procedures for continuous water-quality monitors - Station operation, record computation, and data reporting: U.S. Geological Survey Techniques and Methods, book 1, chap. D3, 51 p., 8 attachments, accessed April 10, 2006, at https://pubs.usgs. gov/tm/2006/tm1d3/.

Whittier, R.B., and El-Kadi, A.I., 2009, Human and environmental risk ranking of onsite sewage disposal systems: Honolulu, University of Hawai'i at Mānoa, School of Ocean and Earth Science Technology, Department of Geology and Geophysics, 72 p.

Whittier, R.B., and El-Kadi, A.I., 2014, Human health and environmental risk ranking of on-site sewage disposal systems for the Hawaiian Islands of Kauai, Maui, Molokai, and Hawaii: Honolulu, University of Hawai'i at Mānoa, School of Ocean and Earth Science Technology, Department of Geology and Geophysics, 257 p. 
Wiegner, T.N., Hughes, F., Shizuma, L.M., Bishaw, D.K., and Manuel, M.E., 2013, Impacts of an invasive $\mathrm{N}_{2}$-fixing tree on Hawaiian stream water quality: Biotropica, v. 45, no. 4, p. 409-418.

Wilde, F.D., 2004, Cleaning of equipment for water sampling (ver. 2.0): U.S. Geological Survey Techniques of WaterResources Investigations book 9, chap. A3, 73 p., accessed May 2019 at https://doi.org/10.3133/twri09A3.

Wilde, F.D., Sandstrom, M.W., and Skrobialowski, S.C., 2014, Selection of equipment for water sampling (ver. 3.1): U.S. Geological Survey Techniques of Water-Resources Investigations, book 9, chap. A2, 78 p., accessed January 23, 2020, at https://doi.org/10.3133/twri09A2.

Williams, T., Foreman, W.T., Decess, J., Reed-Parker, C., and Stevenson, D.L., 2015, Changes to National Water Quality Laboratory (NWQL) procedures used to establish and verify laboratory detection and reporting limits: U.S. Geological Survey National Water Quality Laboratory Technical Memorandum 15.02, accessed June 19, 2019, at https://nwql.usgs. gov/Public/tech_memos/nwq1.2015-02.pdf.

Wilson, J.L., Schumacher, J.G., and Burken, J.G., 2014, Occurrence and origin of Escherichia coli in water and sediment at two public swimming beaches at Lake of the Ozarks State Park, Camden County, Missouri, 2011-13: U.S. Geological Survey Scientific Investigations Report 2014-5005, 59 p., accessed May 15, 2018, at https://doi. org/10.3133/sir20145005.
Xue, D., Botte, J., De Baets, B., Accoe, F., Nestler, A., Taylor, P., Van Cleemput, O., Berglund, M., and Boeckx, P., 2009, Present limitations and future prospects of stable isotope methods for nitrate source identification in surface- and groundwater: Water Research, v. 43, no. 5, p. 1159-1170, accessed September 21, 2018, at https://doi.org/10.1016/j. watres.2008.12.048.

Young, K.D., and Thackston, E.L., 1999, Housing density and bacterial loading in urban streams: Journal of Environmental Engineering, v. 125, no. 12, p. 1177-1180, accessed June 19, 2019, at https://doi.org/10.1061/(ASCE)07339372(1999)125:12(1177).

Zakem, E.J., Al-Haj, A., Church, M.J., van Dijken, G.L., Dutkiewicz, S., Foster, S.Q., Fulweiler, R.W., Mills, M.W., and Follows, M.J., 2018, Ecological control of nitrite in the upper ocean: Nature Communications, v. 9, accessed June 26, 2019, at https://doi.org/10.1038/s41467-018-03553-w.

Zaugg, S.D., Smith, S.G., and Schroeder, M.P., 2007a, Determination of wastewater compounds in whole water by continuous liquid-liquid extraction and capillary-column gas chromatography/mass spectrometry: U.S. Geological Survey Techniques and Methods, book 5, chap. B4, 30 p., accessed April 18, 2018, at https://doi.org/10.3133/tm5B4.

Zaugg, S.D., Smith, S.G., Schroeder, M.P., Barber, L.B., and Burkhardt, M.R., 2007b, Methods of analysis by the U.S. Geological Survey National Water Quality LaboratoryDetermination of wastewater compounds by polystyrenedivinylbenzene solid-phase extraction and capillary-column gas chromatography/mass spectrometry: U.S. Geological Survey Water-Resources Investigations Report 01-4186, 37 p., accessed January 23, 2020, at https://pubs.usgs.gov/wri/ wri014186/.
Moffett Field Publishing Service Center, California

Manuscript approved for publication September 21, 2020

Edited by Taryn A. Lindquist

Layout and design by Kimber Petersen 
ธ

ํㅗㄹ

흥

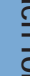

